UNIVERSIDADE DE SÃO PAULO

ESCOLA DE ENFERMAGEM

WANA YEDA PARANHOS

\title{
ANÁLISE DO DESEMPENHO DOS ESTUDANTES DE ENFERMAGEM NO ENSINO POR COMPETÊNCIAS E NO ENSINO PARA COMPREENSÃO.
}

SÃO PAULO

2014 


\title{
ANÁLISE DO DESEMPENHO DOS ESTUDANTES DE ENFERMAGEM NO ENSINO POR COMPETÊNCIAS E NO ENSINO PARA COMPREENSÃO.
}

\author{
Tese apresentada ao Programa de Pós- \\ Graduação em Gerenciamento de \\ Enfermagem - PPGEN da Escola de \\ Enfermagem da Universidade de São Paulo \\ para obtenção do título de Doutora em \\ Ciências. \\ Área de concentração: Fundamentos e \\ Práticas de Gerenciamento em Enfermagem \\ e em Saúde
}

Orientadora: Prof $\stackrel{a}{*}$ Dra $\stackrel{a}{ }$. Maria Madalena Januário Leite 
AUTORIZO A REPRODUÇÃO E DIVULGAÇÃO TOTAL OU PARCIAL DESTE TRABALHO, POR QUALQUER MEIO CONVENCIONAL OU ELETRÔNICO, PARA FINS DE ESTUDO E PESQUISA, DESDE QUE CITADA A FONTE.

Assinatura:

Data:

Catalogação na Publicação (CIP)

Biblioteca "Wanda de Aguiar Horta"

Escola de Enfermagem da Universidade de São Paulo

Paranhos, Wana Yeda

Análise do desempenho dos estudantes de enfermagem no ensino por competências e no ensino para compreensão / Wana Yeda Paranhos. São Paulo, 2014.

$127 p$

Tese (Doutorado) - Escola de Enfermagem da Universidade de São Paulo.

Orientadora: Prof. ${ }^{a}$ Dr. ${ }^{a}$ Maria Madalena Januário Leite

Área de concentração: Fundamentos e Práticas de Gerenciamento em enfermagem e em saúde

1. Enfermagem - educação. 2. Estágios. 3. Avaliação de desempenho - estágio. I. Título. 
Nome: Wana Yeda Paranhos

Título: Análise do desempenho dos estudantes de enfermagem no ensino por competências e no ensino para compreensão.

Tese apresentada ao Programa de Pós-Graduação em Gerenciamento de Enfermagem- PPGEN da Escola de Enfermagem da Universidade de São Paulo para obtenção do título de Doutora em Ciências.

Área de concentração: Fundamentos e Práticas de Gerenciamento em Enfermagem e em Saúde

Aprovado em _ I I

\section{Banca examinadora}

Prof. Dr. Instituição:

Julgamento: Assinatura:

Prof. Dr. Instituição:

Julgamento: Assinatura:

Prof. Dr. Instituição:

Julgamento: Assinatura:

Prof. Dr. Instituição:

Julgamento: Assinatura:

Prof. Dr. Instituição:

Julgamento: Assinatura: 


\section{DEDICATÓRIA}

Dedico a realização deste trabalho

À minha Mãe, D. Dina, sempre presente em minha vida e sua ausência tornou a realização desta tese muito mais difícil.

Saudades eternas! 


\section{AGRADECIMENTOS}

À minha orientadora Prof ${ }^{a}$. Drª . Maria Madalena Januário Leite, por todo apoio, compreensão e amizade.

Às Professoras Dra Claudia Prado e Dr ${ }^{\text {a }}$ Vera Lúcia Mira, pelas valorosas contribuições no Exame de Qualificação.

Aos Professores de estágio, amigos e colegas de trabalho: Adriano, Alessandra, Marcos, Marceli, Valéria, Simone e Valclei, por se esforçarem em sempre fazer o melhor pelos nossos estudantes.

À amiga Patrícia Fera por ser meu braço direito nas decisões que tomo na minha função de coordenadora de curso, você torna tudo mais fácil.

Aos amigos Giuliano e Celso, por me acolherem como irmãos.

Aos meus irmãos Luis Carlos e Wagner e meus sobrinhos Henrique, Rodrigo e Fernando por serem tão importantes na minha vida e entenderem minha ausência durante esse período de estudos.

À amiga Cristiane Domingues por ser meu ombro amigo e minha "irmã" caçula.

Ao Bernardo dos Santos, Estatístico do Serviço de Apoio à Pesquisa, pelo tratamento estatístico dos dados.

A todos que direta ou indiretamente colaboraram com a execução deste trabalho. 
Paranhos, WY. Análise do desempenho dos estudantes de enfermagem no ensino por competências e no ensino para compreensão. [tese]. São Paulo: Escola de Enfermagem, Universidade de São Paulo, 2014.

\section{RESUMO}

Introdução: Como coordenadora de Curso de Enfermagem, vivenciei dois currículos com propostas pedagógicas diferentes levando a seguinte questão em consideração: o desempenho dos estudantes no campo de prática do currículo no modelo da compreensão é diferente dos estudantes do currículo disciplinar? Esta questão motivou a elaboração deste estudo que visa analisar o desempenho dos estudantes de ambos os grupos. Objetivos: Analisar 0 desempenho dos estudantes no estágio curricular supervisionado do projeto pedagógico baseado em Competências e dos estudantes do projeto pedagógico na perspectiva do Ensino Para Compreensão. Método: Estudo exploratório descritivo, documental, quantitativo que se utiliza de comparações entre os dois currículos e as categorias e subcategorias do instrumento de avaliação de estágio curricular supervisionado. O local da pesquisa foi uma universidade privada do município de São Paulo e os instrumentos de coleta de dados foram os documentos de avaliação de desempenho dos estudantes da disciplina em questão, perfazendo um total de 52 estudantes e 312 instrumentos de avaliação. Resultados e Discussão: Os estudantes são, na sua maioria, mulheres, entre 26 e 35 anos de idade, técnicos de enfermagem que trabalham no turno da tarde. A avaliação do desempenho dos estudantes do currículo $A$, não teve diferença em relação à média geral dos estudantes do currículo $\mathrm{B}$. Os estudantes do currículo $A$ mostraram melhor desempenho em relação ao $B$ apenas na unidade de terapia intensiva. $O$ estudante mais velho tem melhor desempenho que 0 mais novo. As mulheres têm desempenho melhor que os homens. Os estudantes que são técnicos de enfermagem têm desempenho melhor que os que são auxiliares de enfermagem e dos que não têm formação na área da saúde. $O$ aluno que trabalha à tarde tem melhores notas na avaliação de desempenho do que aqueles que trabalham à noite $e$ os que não trabalham. Os resultados apontam a necessidade de realizar pesquisas para desmitificar o estudante do turno vespertino, pois existem diversos estudos sobre o estudante e o trabalhador do turno noturno. Conclusão: A hipótese de que o desempenho dos estudantes do currículo modular baseado no marco conceitual do ensino para compreensão era melhor que dos estudantes do currículo por competência não se confirmou. Concluímos também que, como a maioria das variáveis eram as mesmas (campo de estágio, professores e os instrumentos) o currículo passou a ser uma variável de pouca expressão para o resultado final dos alunos. Novas pesquisas são sugeridas para uma melhor interpretação e análise da avaliação de desempenho dos estudantes durante o 
estágio supervisionado, pois acreditamos ser esse o ponto chave da formação do estudante de enfermagem no qual ele aprende fazendo. Consideramos também que esses dados contribuem para um adensamento da linha de pesquisa "formação e gerenciamento de recursos humanos em enfermagem e em saúde" uma vez que aponta a necessidade de melhor estruturação na avaliação de desempenho do estudante no estágio curricular supervisionado e principalmente um processo de capacitação dos professores para a execução dessa atividade.

DESCRITORES: Educação em Enfermagem, Estágio Curricular Supervisionado, Avaliação de Desempenho do Estudante. 
Paranhos, WY. Analysis of performance of nursing students by teaching skills and teaching for understanding. [thesis]. São Paulo: Escola de Enfermagem, Universidade de São Paulo, 2014.

\section{ABSTRACT}

Introduction: As the coordinator of a Nursing Course, I experienced two curricula with different pedagogical proposals taking the following question into consideration: Is the student's performance on the practice field in the curriculum model of understanding different from the student's performance on the disciplinary curriculum? This issue motivated the development of this study in order to analyze the performance of students in both groups. Objectives: To analyze the performance of students in the supervised traineeship of the pedagogical design based on skills and students of the pedagogical project "Teaching For Understanding". Method: A descriptive exploratory study which uses quantitative comparisons between the two curricula and the categories and subcategories of the assessment instrument of the supervised curricular internship. The search location was one private university in São Paulo and the instruments of data collection were documents for performance evaluation of the students of the discipline in question, making a total of 52 students and 312 assessment tools. Results and Discussion: The students are mostly women between 26 and 35 years old, nursing technicians who work in the afternoon. In the performance evaluation of the curriculum, the students had no difference compared with the overall average student of the curriculum B. The student's resume showed better performance compared to $B$ only in the intensive care unit. The older student performs better than the younger one. Women perform better than men. Students who are nursing technicians have better performance than those who are nursing assistants and who have no working experience in healthcare. The student who works in the afternoon have better grades in performance evaluation than those who work at night and do not work. The results indicate the need to conduct research to demystify the student's afternoon shift, because there are many studies about the student and the worker who works at the night shift. Conclusion: The hypothesis that the performance of the students from the modular curriculum based on the conceptual framework for teaching for understanding was better than the students of the curriculum for skills was not confirmed. We also conclude that, as most of the variables were the same, (the training field, teachers and instruments) the curriculum was a variable of little importance for the students' final outcome. Further research to better interpret and analyze the performance evaluation of students during supervised training is suggested, therefore, we believe this is the key point in the training of nursing students, where he learns doing. We also believe that these data contribute in order to intensify the research and training of human resources management in nursing and health 
research field, since it indicates the need of a better structure in the evaluation of student performance in relation to supervised traineeship and mostly a process of training teachers for the implementation of this activity.

DESCRIPTORS: Nursing Education, Supervised Curricular Training, Evaluation of Student Performance. 
Paranhos, WY. Análisis Del desarrollo de los Estudiantes de enfermería en La Enseñanza por competencias y en la Enseñanza para la Comprensión. [tesis]. São Paulo: Escola de Enfermería, Universidade de São Paulo, 2014.

\section{RESUMEN}

Introducción: Como coordinadora del Curso de Enfermería viví la implementación de dos currículos con propuestas pedagógicas diferentes y tuve como cuestión: ¿el desarrollo de los estudiantes en el campo de la práctica del currículo en el modelo de la comprensión es diferente del de los estudiantes del currículo disciplinar? Esa cuestión fue el motivo del presente trabajo que analizó el desarrollo de los estudiantes en esos dos currículos mencionados. Objetivos: Analizar el desarrollo de los estudiantes en las prácticas curriculares del proyecto pedagógico basado en competencias y de los estudiantes del proyecto pedagógico en la perspectiva de la Enseñanza para la Comprensión. Método: Estudio exploratorio descriptivo, documental, cuantitativo que usa comparaciones entre dos currículos y las categorías y sub categorías como instrumento de evaluación de las prácticas curriculares. El local de la investigación fue una Institución de Enseñanza Superior privada, del municipio de São Paulo, y los instrumentos de colecta de datos fueron los documentos de evaluación del desarrollo de los estudiantes de la mencionada disciplina, totalizando 52 estudiantes y 312 instrumentos de evaluación. Resultados y Discusión: Los estudiantes son en mayor número mujeres, entre 26 y 35 años de edad, auxiliares de enfermería que trabajan en el turno de vespertino. La evaluación del desarrollo de los estudiantes del currículo A no presentó diferencia al ser comparada con el promedio general de los estudiantes del currículo B. Los estudiantes del currículo A demostraron mejor desarrollo en relación al B sólo en la unidad de terapia intensiva. El estudiante mayor se desarrolla mejor que el más joven. Las mujeres se desarrollan mejor que los hombres. Los estudiantes que son auxiliares de enfermería se empeñan mejor que los que asistentes de enfermería y de los que no tienen formación en esa área. El alumno que trabaja en el periodo de la tarde obtiene mejores calificaciones en la evaluación de desarrollo que los que trabajan en el periodo nocturno o que no trabajan. Los resultados respaldan la necesidad de realizar investigaciones para desmitificar al estudiante del turno vespertino, pues existen diversos estudios sobre ese estudiante y el trabajador del turno nocturno. Conclusión: La hipótesis de que el desarrollo de los estudiantes del currículo modular basado en el Marco Conceptual de la Enseñanza para la Comprensión era mejor que el de los estudiantes del currículo por competencias no se confirmó. Se concluye, también, que como la mayor parte de las variables eran las mismas, el campo de las prácticas, profesores y los instrumentos, el currículo dejó de ser una variable poco expresiva para el resultado final de los alumnos. Se sugieren nuevas 
investigaciones para mejorar la interpretación y análisis de la evaluación del desarrollo de los estudiantes durante las prácticas curriculares, pues se cree que ese es el punto clave de la formación del estudiante de enfermería, en donde él aprende practicando. Se considera, de igual forma, que esos datos contribuyen para una fundamentación en la línea de investigación Formación y Gestión en Recursos Humanos en Enfermería y en Salud ya que muestran la necesidad de mejorar la estructura de la evaluación del desarrollo del estudiante en las prácticas curriculares y principalmente en el proceso de capacitación de los profesores para ejecutar esa actividad.

DESCRIPTORES: Educación en Enfermería, Prácticas Curriculares, Evaluación del Desarrollo del Estudiante. 


\section{LISTA DE GRÁFICOS}

Gráfico 1 Distribuição do número de alunos por currículo cursado

Gráfico 2 Distribuição do gênero dos estudantes por currículo ministrado

Gráfico 3 Distribuição da idade dos estudantes dos currículos

50 $A$ e $B$

Gráfico 4 Distribuição da formação na área de enfermagem dos estudantes dos currículos A e B

Gráfico 5 Distribuição dos estudantes trabalhadores dos currículos $\mathrm{A}$ e $\mathrm{B}$

Gráfico 6 Distribuição do turno de trabalho dos estudantes trabalhadores dos currículos A e B.

Gráfico 7 Média geral da avaliação de desempenho dos estudantes dos currículos A e B.

Gráfico 8 Média das avaliações de desempenho dos estudantes por rodízio dos currículos $\mathrm{A}$ e $\mathrm{B}$

Gráfico 9 Distribuição das médias da avaliação de desempenho dos estudantes por categoria do instrumento de avaliação, currículos A e B.

Gráfico 10 Distribuição das notas da avaliação do rodízio um de acordo com o currículo cursado

Gráfico 11 Distribuição das notas da avaliação do rodízio dois de acordo com o currículo cursado

Gráfico 12 Distribuição das notas da avaliação do rodízio três de 62 acordo com o currículo cursado

Gráfico 13 Distribuição das notas da avaliação do rodízio quatro de acordo com o currículo cursado

Gráfico 14 Distribuição das notas da avaliação do rodízio cinco de acordo com o currículo cursado

Gráfico 15 Distribuição das notas da avaliação do rodízio seis de acordo com o currículo cursado 


\section{LISTA DE QUADROS}

Quadro 1 Médias por categorias do instrumento de avaliação 57

Quadro 2 Distribuição das notas da avaliação do rodízio um de 59 acordo com o currículo cursado

Quadro 3 Distribuição das notas da avaliação do rodízio dois de 60 acordo com o currículo cursado

Quadro 4 Distribuição das notas da avaliação do rodízio três de 62 acordo com o currículo cursado

Quadro 5 Distribuição das notas da avaliação do rodízio quatro de 63 acordo com o currículo cursado

Quadro 6 Distribuição das notas da avaliação do rodízio cinco de 64 acordo com o currículo cursado

Quadro 7 Distribuição das notas da avaliação do rodízio seis de 66 acordo com o currículo cursado

Quadro 8 Comparação das subcategorias que demonstraram 67 diferença estatística quando comparado o gênero dos estudantes

Quadro 9 Comparação das subcategorias que demonstraram diferença estatística quando comparado o gênero dos estudantes

Quadro 10 Comparação das subcategorias que demonstraram 70 diferença estatística quando comparado a formação na área de enfermagem.

Quadro 11 Comparação das subcategorias e o turno de trabalho dos estudantes. 


\section{SUMÁRIO}

1. Introdução ......................................................... 17

1.1. Ensino de enfermagem no cenário de estudo ......... 19

1.1.1. Ensino por competências ..................................... 20

1.1.2. Ensino para compreensão ................................... 21

1.2. Currículos por competência e para compreensão ... 23

1.2.1. Currículo no modelo disciplinar baseado no ensino por competências ……...................................... 23

1.2.2. Currículo modular na perspectiva do ensino para compreensão ..................................................... 27

1.3. Avaliação de desempenho ................................... 32

2. Objetivo geral .............................................. 37

2.1. Objetivos específicos ……………………........ 37

3. $\quad$ Material e método …........................................ 38

3.1. Contexto do estudo ........................................... 38

3.1.1. Estágio curricular supervisionado .......................... 38

3.2. Material ......................................................... 40

3.3. Procedimento...................................................... 40

3.3.1. Instrumento de avaliação para o estágio em atenção básica .................................................. 41

3.3.2. Instrumento de avaliação para o estágio em unidade de internação e UTI ................................. 42

3.3.3. Instrumento de avaliação para o estágio de gestão 44

3.4. Aspectos éticos ................................................... 46

3.5. Análise dos dados ............................................. 47

4. $\quad$ Resultados e discussão ……………………........ 48

4.1. Caracterização dos estudantes ............................ 48

4.2. Análise do desempenho ..................................... 53

4.3. Comparação do desempenho dos estudantes de acordo com as características de identificação ....... $\quad 57$

5. Conclusões ....................................................... 74

6. Referências Bibliográficas …................................ 77

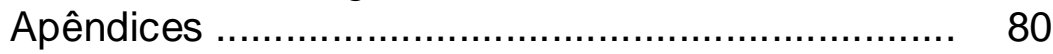

Anexos ................................................... 108 
1. INTRODUÇÃ 0 


\section{INTRODUÇÃO}

Graduada em 1985, atuei como enfermeira no Hospital das Clínicas da Faculdade de Medicina da USP desde 1986, onde ocupei os cargos de enfermeira, enfermeira encarregada, enfermeira chefe e assistente técnico de divisão de enfermagem. Durante minha atuação no hospital sempre participei de atividades de educação, tais como, treinamentos e no curso de aprimoramento em enfermagem em Pronto Socorro. Sempre tive interesse nessa área. Em 1993, fiz o curso de especialização em Estomaterapia pela Escola de Enfermagem da USP e, após concluir o curso, acompanhei estágio das turmas posteriores à minha. Em 1995 entrei no programa de mestrado na escola de enfermagem da USP, concluído em 1999. Nesta ocasião decidi ingressar na área de ensino. Comecei a lecionar no curso de graduação em enfermagem em uma universidade privada, na qual estou até hoje.

A partir de 2008 ocupo o cargo de Coordenadora do Curso de Graduação em Enfermagem de uma instituição de ensino privada do município de São Paulo e, desde que ocupei este cargo tenho a preocupação com a qualidade da formação dos estudantes do curso que coordeno.

A Universidade também tem esta preocupação e em 2009 foi proposto pela Pro Reitoria de Ensino (ProEn), uma mudança curricular em todos os cursos da Universidade para uma estrutura modular, o Curso de Graduação em Enfermagem portanto, passou adotar também esta estrutura.

Na mesma ocasião foi proposto também pela ProEn um curso de especialização lato sensu em Docência no Cenário do Ensino para Compreensão (EpC), em que todos os professores da Universidade foram convidados a participar, com o objetivo de implantar este modelo para todos os Cursos de Graduação. ${ }^{1}$ 
O EpC é um marco teórico iniciado por pesquisadores da Harvard Graduate School of Education que estudam a cognição humana em uma variedade de domínios e buscam aplicar suas descobertas à melhoria da reflexão, do ensino e da aprendizagem em cenários educacionais diversos, procuram os melhores esforços para ensinar para a compreensão, que eles denominaram como um processo complexo. ${ }^{2}$

O marco conceitual está pautado na definição dos tópicos geradores, estabelecimento de metas de compreensão, desempenhos de compreensão e na avaliação contínua. Esses quatro momentos devem estar introjetados no professor, de maneira que ele consiga transitar com segurança nesse marco conceitual e serão explicados posteriormente.

Dessa forma, a partir de 2009, os cursos de graduação passaram a ser neste novo modelo, modular, em simultaneidade ao disciplinar, que ainda continuava a acontecer nos currículos em andamento.

Dentro desse contexto, passamos a vivenciar os dois currículos e começamos a perceber empiricamente que os estudantes dos dois modelos pedagógicos tinham aproveitamentos diferentes. E iniciamos uma reflexão se de fato existe esta mudança de aproveitamento ou se isso é somente a percepção do professor?

Nesse processo reflexivo surgiram algumas questões: o desempenho dos estudantes no campo de prática do currículo no modelo da compreensão é diferente dos estudantes do currículo disciplinar? Há diferença de desempenho no campo de prática nas dimensões comportamental e atitudinal, conhecimento científico, prática assistencial, ações educativas e produção de trabalhos? A média dos estudantes do currículo por compreensão é diferente da média dos estudantes por disciplinas na avaliação de desempenho durante o campo de prática? 
Com essas preocupações procurei recursos na Escola de Enfermagem da USP, com a intenção de me aprimorar nas questões sobre a qualidade do ensino e os processos de avaliação, passei a participar de dois grupos de pesquisa: Avaliação das práticas do ensino e da assistência à saúde, sob Coordenação da Professora Doutora Madalena Januário Leite; e o grupo de Estudos e Pesquisas de Tecnologia da Informação nos Processos de Trabalho em Enfermagem, sob Coordenação das Professoras Doutoras Heloisa Helena Ciqueto Peres e Claudia Prado, quando surgiu o interesse em ingressar no programa de doutorado do Programa de Pós Graduação Gerenciamento em enfermagem - PPGEn.

Essas questões motivaram a elaboração deste estudo que visa analisar o desempenho dos estudantes de ambos os grupos durante o estágio curricular supervisionado e analisar se a nossa percepção de que o estudante do currículo modular na perspectiva do ensino para compreensão tem um desempenho mais satisfatório que o estudante do currículo disciplinar é verdadeira.

\subsection{O ENSINO DE ENFERMAGEM NO CENÁRIO DO CAMPO DE ESTUDO}

A Universidade, cenário do estudo, foi criada na década de 70 e o Curso de Enfermagem, em 1981, e sempre foi considerado um curso de qualidade que respeita as diretrizes curriculares nacionais para os cursos de graduação.

A Universidade vem passando por processos de mudanças curriculares desde o início dos anos 2000. Esse fato ocorre por existir uma constante discussão do processo ensino-aprendizagem, formas e conteúdos programáticos. Até 2001, o curso era constituído no modelo disciplinar, com disciplinas tradicionais como anatomia, bioquímica, enfermagem pediátrica, enfermagem ginecológica e enfermagem médico-cirúrgica. De 2002 a 2008, o currículo ainda disciplinar, mas já com um formato de disciplinas integradas como 
bases morfofisiológicas, bases bioquímicas, instrumentos de enfermagem, ciclo vital (situações prevalentes), situações especiais, entre outras, numa perspectiva por competências.

Em 2009, foi proposto pela PROEn, como já citado anteriormente, o currículo modular na perspectiva da compreensão, que passa a funcionar com Unidades Curriculares de Graduação (UCGs).

Portanto, a partir de 2009, passamos a vivenciar os dois modelos curriculares que serão descritos posteriormente.

\subsubsection{Ensino por competências}

O processo de ensino baseado em competências significa, primordialmente, reconhecer que as relações do mundo estão mudadas, e que, sendo assim, a formação educacional do profissional também precisa ser outra. ${ }^{3}$

As discussões sobre um ensino por competências, tanto na formação geral como na profissional, com ênfase para esta última, surgem nas décadas de 1960 e 1970, dependendo de cada país. Desde o início, a noção de competências esteve associada à ideia de formação e tende a substituir a noção de saberes na educação geral e a noção de qualificação na formação profissional, embora não sejam sinônimos. ${ }^{4}$

Uma primeira interpretação para as competências seria a de uma qualificação acrescida de um saber-fazer, incluindo-se atitudes do empregado no ambiente de trabalho.

As Diretrizes Nacionais (DCNs) para o curso de enfermagem definem as seguintes competências gerais para os egressos de enfermagem: Atenção à saúde; Tomada de decisões; Comunicação Liderança; Administração e Gerenciamento; Educação Permanente. E como competências específicas, as diretrizes definem que o 
Enfermeiro deve possuir, também, competências técnico-científicas, ético políticas e sócio-educativas contextualizadas. ${ }^{5}$

Para Zabalza, ${ }^{6}$ habilidade e competência têm o mesmo significado, uma vez que o autor refere que habilidade ou competência tem o fato positivo de que dirige seu olhar mais para o processo do que para o resultado, de como o sujeito enfrenta a tarefa de aprender e a capacidade de lançar mão desse aprendizado e como lidam com ele.

Este mesmo autor define a habilidade em três níveis, a saber: 1) estrutural básica, quando é estimulada no estudante a percepção, memória e atenção; 2) operacional cognitivo, quando os estudantes são capazes de fazer uso dos seus recursos cognitivos e tirar proveito de suas capacidades naturais; e, por fim, 3) capacidade de absorção, esta habilidade está no estudante reconhecer um novo conhecimento e para aplicá-los às finalidades desejadas, para isso este deve utilizar as experiências prévias de aprendizagem, assim como o conhecimento advindo delas.

No currículo por competência, essa é entendida como a capacidade de mobilizar um conjunto de recursos ou atributos cognitivos, afetivos e psicomotores, relações, valores, postura, cultura, princípios éticos, destrezas e habilidades para solucionar com pertinência e eficácia as situações profissionais. ${ }^{7}$

Sendo assim, podemos dizer que ensinar por competência pretende formar enfermeiros com as competências definidas nas DCNs, e a habilidade de usá-las para desenvolver os desempenhos que se fizerem necessários a sua atuação profissional, visando ao mercado de trabalho.

\subsubsection{Ensino para compreensão}

O EpC é um marco teórico iniciado por pesquisadores da Harvard Graduate School of Education que estudam a cognição 
humana em uma variedade de domínios e buscam aplicar suas descobertas à melhoria da reflexão, do ensino e da aprendizagem em cenários educacionais diversos. Esses procuram os melhores esforços para ensinar para a compreensão, que eles denominaram como um processo complexo. ${ }^{2}$

O EpC não é uma metodologia de ensino, mas sim um marco conceitual que concebe a aprendizagem como construção interna, flexível e de integração de significados a partir da participação ativa do indivíduo que aprende; considera a flexibilidade cognitiva do aluno e a clara interdependência entre os saberes, como pontos fortes para a promoção da aprendizagem colaborativa e interdisciplinar.

Este marco conceitual foi construído a partir de um projeto desenvolvido na Universidade de Harvard em conjunto com outras instituições. A compreensão, segundo Wiske (pág. 53)², "é concebida como a capacidade de uma pessoa usar seu conhecimento de maneira inovadora".

As pesquisas desenvolvidas pelos mentores do EpC, evidenciaram que trilhar os caminhos do ensino para a compreensão é de extrema complexidade, pois exige mais do que ideias sobre a natureza da compreensão e do seu desenvolvimento. Um marco conceitual guia deve abordar quatro questões-chave, a primeira que tópicos valem a pena compreender? Segunda o que os estudantes precisam compreender sobre eles? Terceira como podemos estimular a compreensão? Quarta como podemos saber o que os estudantes compreendem? (WISKE, pág. 53) ${ }^{2}$

Essas questões foram respondidas a partir das pesquisas que deram origem ao marco conceitual, o qual foi desenvolvido sobre quatro pilares, denominados tópicos geradores, metas de compreensão, desempenhos de compreensão e avaliação contínua. ${ }^{2}$

O tópico gerador define o que vale a pena compreender ao identificar tópicos ou temas geradores e organizar o currículo em torno deles. A meta de compreensão esclarece o que os estudantes precisam compreender ao articular metas claras centradas em compreensõeschave; o desempenho de compreensão estimula a aprendizagem dos estudantes ao engajá-los em 
desempenhos de compreensão que requerem deles a aplicação, a ampliação e a síntese do que sabem, assim como monitora e promove o progresso dos aprendizes por intermédio de avaliações contínuas de seus desempenhos a partir de critérios diretamente relacionados às metas de compreensão (WISKE, pág. $53)^{2}$

O marco conceitual está pautado na definição dos tópicos geradores, estabelecimento de metas de compreensão, desempenhos de compreensão e na avaliação contínua. Estes quatro momentos devem estar introjetados no professor, de maneira que ele consiga transitar com segurança neste marco conceitual.

Os tópicos geradores são questões ou temas centrais e fundamentais à formação do aluno e que estejam relacionados às suas experiências e interesses, que possam ser abordados de diversos prismas e que estejam ligados às paixões dos professores. As metas de compreensão são balizadas por um verbo que mostre de maneira objetiva o que se espera que o aluno compreenda. Os desempenhos de compreensão refletem os desempenhos esperados do aluno em relação às metas de compreensão. A avaliação contínua deve ser realizada ao final de cada atividade.

\subsection{CURRÍCULOS POR COMPETÊNCIAS E POR COMPREENSÃO}

Este estudo foi realizado comparando o desempenho dos estudantes em dois currículos distintos, porém com muitas semelhanças. Antes de descrever cada um dos currículos, vale ressaltar que o grupo de professores que pensou, desenvolveu e praticou os dois currículos, foi o mesmo.

A seguir estão descritos os dois currículos:

\subsubsection{Currículo no modelo disciplinar baseado no ensino por competências:}

Este currículo teve início em 2006, e nele houve a preocupação de oferecer ao estudante oportunidade para pensar nas realidades de saúde e criar instrumentos e atitudes necessárias 
para tal desafio, desenvolvendo competências para investigar, detectar problemas e tomar decisões, reconhecendo os critérios legais e trabalhistas, específicos dessa área. (Anexo 1)

O conteúdo curricular abordado para a consecução do perfil profissional desejado forneceu os caminhos para formação de um enfermeiro que desenvolvesse atividades preventivas, curativas e de promoção à saúde para o indivíduo, família e comunidade.

Desta maneira, o objetivo do curso era desenvolver estratégias didático-pedagógicas a fim de promover no egresso as competências descritas a seguir:

\section{Competências, habilidades e atitudes:}

\section{Competências:}

- Ser um enfermeiro capaz de conhecer os problemas do paciente, família e comunidade, com vista à proposição de soluções e suas implementações baseado em esquemas racionais e na reflexão sensível frente à ação profissional.

- Ser enfermeiro capaz de interagir com a pessoa/ família/ comunidade, reconhecendo na interação seu próprio fim ou ainda um instrumento de intervenção.

- Ser enfermeiro capaz de promover educação em saúde, baseado nos princípios da cidadania, da participação e da solidariedade.

- Ser enfermeiro capaz de desenvolver investigação de cunho científico, empírico ou experimental, reconhecendo nestas a construção e a sustentação do conhecimento na área de enfermagem.

- Ser enfermeiro capaz de cuidar na relação direta a pessoal família/ comunidade e na coordenação da assistência de enfermagem/ prestação do cuidado, distinguindo seus contextos humano, situacional e geral. 
- Ser enfermeiro capaz de comprometer-se com o desenvolvimento técnico-científico da profissão

Nesse sentido, o curso ofereceu uma estrutura curricular composta por quatro eixos temáticos que possibilitavam, a partir das representações dos estudantes sobre conceitos do processo saúdedoença, organizar as abordagens durante o curso, fazendo uso das disciplinas contidas nestes eixos temáticos como fonte de reconstrução, elaboração e enriquecimento de práticas, que certamente contribuíram para a formação do enfermeiro. Nesse currículo, as disciplinas ocorreram com integração de conhecimentos, portanto, diferente dos cursos tradicionais as disciplinas tinham carga horária maior e eram ministradas por mais de um professor, constituindo assim as bases e ciclos de conhecimento. São eles:

Compreensão do processo saúde-doenca (no $1^{\circ}$ e $2^{\circ}$ semestres). Nesse eixo, são abordados conhecimentos teóricos e realizadas práticas em laboratórios específicos sobre Bases Morfofisiológicas do Organismo Humano I e II (Anatomia, Fisiologia); Bases Bioquímicas do Organismo Humano I e II (Histologia, Bioquímica); Contexto Epidemiológico I e II (Epidemiologia, Bioestatística); Construção do Conhecimento na Área da saúde (Introdução à Pesquisa em Bases de Dados); Antropologia Cultural e Instrumentos de Enfermagem I e II (Anamnese, Exame Físico e Avaliação de Saúde).

Instrumentalizacão para a abordagem do processo saúdedoenca (no $3^{\circ}$ e $4^{\circ}$ semestres). Esse eixo propiciava o aprendizado de processos patológicos gerais - Bases Fisiopatológicas do Organismo Humano I e II (Patologia, Imunologia, Microbiologia e Farmacologia), iniciava a aplicação do processo de raciocínio crítico e do processo de cuidar na disciplina Instrumentos de Enfermagem III, introduzia o conhecimento das Metodologias de Pesquisa em Enfermagem e aborda os fundamentos do ciclo vital 
em situação saudável - teoricamente e através de práticas supervisionadas na comunidade - (criança, adolescente, adulto e idoso) na disciplina de Enfermagem no Ciclo Vital.

\section{Fundamentacão do Processo de Trabalho do Enfermeiro} (no 5 e 6을 semestres). Nesse eixo eram abordados os fundamentos teóricos e práticos do Ciclo Vital em Situações Prevalentes (Situações de Doença do Adulto) e em Situações Especiais (Saúde da Mulher, Saúde da Criança, Saúde Mental e Situações de Urgência e Emergência), a Educação em Saúde como ferramenta de trabalho do profissional Enfermeiro, os procedimentos técnicos de enfermagem e a Gestão em Saúde, discutida em processos de trabalho do enfermeiro nos diferentes cenários.

Intervenção no processo saúde-doença (no $7^{\circ}$ e $8^{\circ}$ semestres). Esse eixo destinava-se ao Estágio Curricular Supervisionado (ECS). O estágio compreendia vários cenários de saúde (hospitais gerais e especializados e Unidades Básicas de Saúde), em que o estudante construiu uma visão global dos conteúdos, de maneira significativa, garantindo a percepção e a compreensão dos eixos do curso, na integração desses diversos cenários pelos quais ele transitava.

Nesse currículo houve a preocupação de integração dos conhecimentos, os conteúdos se integravam em disciplinas constituindo as bases do conhecimento, onde os professores trabalhavam em equipe.

Em relação ao processo de avaliação foram definidas algumas diretrizes gerais e pressupostos da avaliação continuada de forma sistematizada, interativa e flexível. O processo de avaliação foi fundamentado sobre as dimensões conceitual, procedimental e atitudinal, por meio da utilização de diferentes formatos de avaliação como, por exemplo: oral, escrito, provas, testes, trabalhos individuais e de grupo, observações sistemáticas entre outros. 
Os pressupostos da avaliação de aprendizagem eram que todo e qualquer procedimento de avaliação devia ser precedido da clara divulgação dos seus objetivos, e a qual a competência se referia. A divulgação dos resultados de avaliação era obrigatória e compreendia a devolução na íntegra dos instrumentos e materiais usados, com a devida explicitação da condição alcançada pelo estudante, face ao objetivo proposto. A avaliação contemplava a progressão de conhecimentos, habilidades e atitudes e a diretoria do curso devia ter ciência do desenvolvimento das avaliações pelas disciplinas e componentes curriculares. ${ }^{18}$

A avaliação da aprendizagem pelo professor pressupunha a análise do estudante, construindo conhecimentos individualmente e na sua relação com o outro, uma tentativa de aproximação, ao máximo possível, daquilo que o estudante aprendeu.

Também, era utilizada a avaliação formativa que é o ato de ensinar avaliando e promovendo diferentes saberes. Portanto, seus instrumentos devem ser eles mesmos, situações de aprendizagem. ${ }^{19}$

\subsubsection{Currículo modular na perspectiva do ensino para} compreensão.

Esse currículo teve início em 2009, numa estrutura modular e como concepção de ensino aprendizagem era utilizada o Ensino para a Compreensão (EpC). (Anexo 2)

Referente à organização didático-pedagógica, o objetivo do curso era desenvolver no egresso, desempenhos que o capacitassem a conhecer os problemas do paciente, família e comunidade com vistas à implementação e coordenação da assistência de enfermagem nos eixos promoção, prevenção, tratamento e reabilitação, fundamentados cientificamente e também a capacitá-lo a desenvolver investigação de cunho científico. 
Neste sentido, o curso oferecia uma estrutura curricular composta por módulos divididos em eixo comum, eixo específico, core currículo e o ECS, que possibilitavam aos estudantes o conhecimento e a compreensão sobre conceitos do processo saúdedoença, fazendo uso das Unidades Curriculares de Graduação (UCGs) contidas nestes módulos como fonte de reconstrução, elaboração e enriquecimento de práticas, que certamente contribuiriam para a formação do enfermeiro. ${ }^{20}$

As UCGs são de 160 h/a e integravam conhecimentos como descritos abaixo, ministradas por mais de um professor que dominavam os temas abordados. São eles:

Eixo comum da saúde: Nesse eixo eram abordados temas comuns a todos os profissionais da área (enfermagem, biomedicina, fisioterapia e odontologia), dividido em dois módulos. Os módulos eram ministrados por professores de diversas formações na área da saúde.

Aproximacão em saúde: Esse módulo era composto por duas UCGs, a primeira, Saúde Coletiva, em que eram tratados os conteúdos de saúde coletiva, epidemiologia e noções de gestão de serviços de saúde; e a segunda, Ser Humano em Relação, abordava os conteúdos de psicologia, antropologia, ética e bioética, além do início da construção do conhecimento na área da saúde e o processo de pensamento crítico.

Conhecimentos e habilidades na dimensão biológica: Era composto pelas UCGs de Metabolismo Controle e Homeostase que abordava os conteúdos de bioquímica e fisiologia e a UCG Constituição e desenvolvimento humano em que eram abordados os temas de anatomia e histologia. Os estudantes eram apresentados a conhecimentos teóricos e eram realizadas práticas em laboratórios específicos sobre Anatomia, Fisiologia, Histologia, Biologia, Bioquímica. 
No eixo comum da saúde, os estudantes de todos os cursos da área conviviam no mesmo ambiente de ensino aprendizagem e tinham professores das diversas profissões. O principal objetivo era que o estudante compreendesse que a área da saúde é uma área de atuação multiprofissional, e que se formassem profissionais com essa competência de trabalho.

\section{Eixo específico de enfermagem}

A partir do terceiro módulo, e até o final do curso, o estudante começa a cursar o eixo específico de enfermagem, separando-se dos estudantes dos outros cursos da saúde. Este era composto pelos seguintes módulos:

Agressão e defesa e biosseguranca: Esse módulo composto pelas UCGs Mecanismo de Agressão e Defesa e Avaliação da Saúde do Indivíduo. Na primeira, tinham os conteúdos de fisiopatologia, imunologia, microbiologia e parasitologia; e na segunda, os estudantes aprendiam a realização de exame físico, anamnese.

Semiologia, semiotécnica e farmacologia: Nesse módulo os estudantes tinham duas UCGs, a primeira é Farmacologia e Semiotécnica, que visava desenvolver competências e habilidades em farmacoterapia, através do estudo da ação dos medicamentos nos diferentes sistemas do organismo e a assistência de enfermagem no preparo e administração de medicamentos. A segunda é a UCG Processos Morfofuncionais na qual os estudantes iniciavam a compreensão do funcionamento normal do organismo e como é possível perceber isso através de exames de sangue e de imagem.

Atenção Primária e Secundária à Saúde do Indivíduo: As duas UCGs que compõem este módulo eram Atenção Primária e Secundária à Saúde do Indivíduo, Família e Comunidade. Os estudantes eram apresentados à assistência de enfermagem nas 
situações mais prevalentes no âmbito da atenção primária e secundária à saúde. Conceitos de promoção de saúde, principais programas e políticas públicas de saúde, também eram abordadas as principais causas de internação de crianças, adultos e idosos com destaque para a sistematização da assistência de enfermagem e, Processo de Trabalho do Enfermeiro, conceitos básicos de sistematização da assistência de enfermagem, pensamento crítico e raciocínio clínico. Os estudantes estudavam e praticavam em situações simuladas em laboratório o levantamento de dados, estabelecimento dos diagnósticos de enfermagem e de plano de cuidados. Conceitos de educação em saúde também eram estudados e os estudantes desenvolviam projetos para desenvolvimento na comunidade.

\section{Atenção terciária à saúde do indivíduo, família e comunidade composto por duas UCGs, Atenção Terciária à} Saúde do Indivíduo, Família e Comunidade. O estudante aprendia as especialidades, pronto socorro, cuidados intensivos e saúde mental e a outra UCG é Gestão em Enfermagem, em que o estudante aprendia sobre os processos gerenciais em serviços de enfermagem.

Estágio curricular supervisionado: que acontecia no $7^{\circ}$ e $8^{\circ}$ semestres. O estágio compreendia vários cenários de saúde (hospitais gerais e especializados e Unidades Básicas de Saúde), em que o estudante construía uma visão global dos conteúdos, de maneira significativa, garantindo a percepção e a compreensão dos eixos do curso, na integração desses diversos cenários pelos quais ele transita. $O$ estudante estagia em unidades de internação adulto e infantil, unidades básicas de saúde e unidade de terapia intensiva no estágio assistencial e ainda passavam no estágio de gestão em unidades de internação e ambulatorial.

Core Curriculum: é o conjunto de conhecimentos, habilidades e atitudes que a Universidade defende para a formação no ensino 
superior, é comum a todos os graduandos e tem coerência na concepção de cada módulo, nas propostas metodológicas, formando uma unidade. Congrega, portanto, estudantes de diferentes cursos de graduação da instituição, que optam pela área de seu interesse a cada semestre. As atividades são obrigatórias e são desenvolvidas a partir do primeiro semestre do curso, em módulos de 15 semanas, com carga horária de $50 \mathrm{~h}$.

Em relação à avaliação do processo ensino aprendizagem se dava através de normas previstas na instituição por meio de resoluções internas. Os professores deviam, no início de cada período letivo, informar os estudantes sobre o plano de ensino, a forma das atividades avaliativas, a periodicidade os valores atribuídos e critérios adotados para avaliação.

Os pressupostos da avaliação também foram baseados para a execução do processo de avaliação formativa. ${ }^{19}$

No ECS, o estudante tinha conhecimento do instrumento de avaliação além de receber antes do início do estágio o manual de orientações. Nele constam os objetivos e critérios de cada campo de estágio. As avaliações seguiram as características específicas apresentadas por cada campo. Foi considerado aprovado o estudante que possuía nota igual ou superior a 6,0 (seis).

Comparando os dois currículos, as semelhanças eram que ambos os currículos tiveram o mesmo corpo docente, os mesmos espaços educacionais, incluindo os campos de estágio, um teve início em 2006 e o outro 2009, o último ano dos dois currículos aconteceu no mesmo período, a última turma que cursou o primeiro currículo começou no segundo semestre de 2008 e cursou o estágio curricular no segundo semestre de 2011 e no primeiro semestre de 2012. O currículo que teve início no primeiro semestre de 2009 cursou o estágio curricular no ano de 2012. No primeiro semestre de 2012, os estudantes estagiaram, nos mesmos espaços com os 
mesmos professores e foram avaliados através dos mesmos instrumentos.

As diferenças estão no desenvolvimento das atividades teóricas. No primeiro currículo, a estrutura de disciplinas acontecia no formato de bases ou ciclo vital, o que não era um modelo disciplinar tradicional, pois em cada uma trabalhavam no mínimo dois professores que ministram as aulas, conforme já explicado anteriormente. $\mathrm{E}$ os pressupostos educacionais, o primeiro baseado em competências e o segundo na perspectiva do ensino para compreensão.

\subsection{AVALIAÇÃO DE DESEMPENHO}

Quando se pensa na avaliação do estudante de enfermagem em campo de prática, deve se pensar na avaliação de desempenho, porque se trata do momento de aplicação dos conteúdos aprendidos ao longo do curso. O momento de desempenhar a função para qual está se formando, ou seja, saber/ser enfermeiro e saber/fazer enfermagem.

Para tanto, buscou se a definição de desempenho.

Segundo o dicionário Michaelis, desempenhar é fazer o que estava empenhado, Cumprir: Desempenhar um dever. Cumprir as suas obrigações ou compromissos: Desempenhemo-nos de nossas obrigações. Desempenhar uma função, um cargo. ${ }^{8}$

Com essa definição confirma- se que a avaliação de estágio supervisionado, é de fato, avaliação de desempenho.

O termo avaliação tem como aspecto consensual sua característica de atribuição de valor. A avaliação de desempenho é definida como um processo de mensuração da qualidade de trabalho, individual, sistematizada e com critérios bem definidos e com possibilidade de desenvolvimento de pessoal e treinamento. ${ }^{9}$ 
$\mathrm{Na}$ perspectiva da avaliação de desempenho profissional, deve ser entendida como instrumento do processo de trabalho, permitindo indicativos de aperfeiçoamento e adequação para a produção do cuidado em saúde.

Na perspectiva da avaliação de desempenho em campo de estágio, em que pese seu caráter classificatório, a avaliação de desempenho pode representar um instrumento que favoreça o estudante, o professor e a universidade ao indicar ajustamentos, necessidades de capacitação e condições de trabalho. ${ }^{10}$

Colaborando com esse pensamento, há autores que dizem que a avaliação de desempenho, deve ser entendida como instrumento do processo de trabalho, permitindo indicativos de aperfeiçoamento e adequação para a produção do cuidado em saúde. ${ }^{11}$

A lei de exercício profissional n. 7.498/1986 define que as atividades do enfermeiro são: planejamento, organização, coordenação, execução e avaliação da assistência de enfermagem, consulta, prescrição da assistência de enfermagem, prestação diretos ao doente crítico e com risco de vida e de cuidados de maior complexidade que exigem conhecimentos específicos e tomada de decisão, entre outros. ${ }^{12}$

Nesse contexto, pode se entender que o instrumento de avaliação deve compor todas as categorias aprendidas durante 0 curso e que são fundamentais para saber fazer/ser enfermeiro.

Uma das dificuldades encontradas pode ser a falta de aptidão dos estudantes por algumas áreas, uma vez que como a formação é generalista, o estudante passa pelas diversas unidades que possa vir a atuar como profissional, e isso talvez torne o processo de avaliação algo mais complexo.

O professor também se vê num momento difícil, uma vez que tem medo de fazer injustiça, quando se avalia o desempenho do 
aluno, também se avalia o resultado do ensino. Se os estudantes aprenderam significa que os professores ensinaram bem. ${ }^{13}$

Outra pesquisa sobre critérios de avaliação no estágio curricular dá ênfase à capacidade do estudante utilizar os conhecimentos e habilidades adquiridos para o exercício profissional e a capacidade de usar o conhecimento adquirido ao longo do curso. $^{14}$

A avaliação deve usar métodos e instrumentos que indiquem exatamente o que o prof essor quer, e o aluno deve ter ciência desse instrumento.

Existe a necessidade de preparo do professor uma vez que se reconhece o processo de avaliação precisa ser pensado, planejado e realizado de forma integrada e coerente com todo processo de ensino-aprendizagem. ${ }^{15}$

Segundo Friedländer ${ }^{16}$, a mais importante finalidade da avaliação de estágio é obter informações úteis ao desenvolvimento do aluno, do professor e da equipe multiprofissional e o avaliador não pode se distanciar dessa finalidade. A avaliação deve respeitar princípios éticos e os avaliados devem ter conhecimento dos resultados. Nenhuma avaliação é isenta e imparcial, mas todos os cuidados devem ser tomados para minimizar os problemas que avaliações parciais podem gerar.

Pensando na fala da autora supracitada, é importante que se saiba a teoria que envolve esse processo de avaliação.

A avaliação da aprendizagem no ensino superior é muito complexa e para compreender essa complexidade é imprescindível conhecer os conceitos e os significados desse processo para os indivíduos envolvidos nele. 
Para compreender o papel da avaliação é importante perceber os princípios que embasam os julgamentos feitos pelos professores.

Vários autores definem avaliação. A seguir algumas dessas definições:

Fleming $^{17}$ diz que a avaliação torna possível a alguém descrever ou sumarizar padrões de desenvolvimento num determinado tempo. Envolve a determinação de meios de reunir evidências, a fim de verificar se as mudanças previstas ocorreram realmente.

Para Perrenoud ${ }^{18}$, avaliar é criar uma hierarquia de excelência em função das quais se definirá se haverá a progressão; também é uma maneira de definir um aluno modelo, os estudantes são comparados e depois classificados.

Sacristán ${ }^{19}$ diz que é uma atividade que se desenvolve seguindo certos usos, que cumpre várias funções e apoia uma série de ideias e formas para realizá-la, e suas respostas são determinadas pelo ensino da instituição.

Esteban ${ }^{20}$ refere que avaliar é uma situação que sempre gera dúvidas e tensão decorrente da necessidade de se chegar a uma conclusão sobre a aprendizagem do estudante.

Sobre essas palavras, deve se ter em vista que a avaliação é um processo incômodo tanto para quem é avaliado como para o avaliador, produzindo momentos de resistência.

Perrenoud também faz um questionamento sobre se a avaliação é feita a serviço da seleção ou a serviço da aprendizagem $?^{18}$

Ao ler essas questões também deve se questionar e ter em mente que a avaliação de desempenho deve ser feita a serviço da 
aprendizagem, o momento de avaliação deve fazer parte do processo de aprendizagem.

Para Luckesi ${ }^{17}$, é necessário que os educadores invistam na "aprendizagem da avaliação", necessitamos disso porque temos a habilidade de examinar, uma vez que, como estudantes, fomos examinados, portanto, repetimos o que os nossos educadores fizeram. Para isso precisamos aprender os conceitos teóricos sobre avaliação e também aprender a praticar a avaliação. $O$ autor também descreve que aprender conceitos é fácil, o difícil é colocálos em prática.

Na prática educativa, numa abordagem por competências, a avaliação deixa de ser centrada em disciplinas e passa a ser verificada por meio de situações e tarefas específicas. ${ }^{7}$

$\mathrm{Na}$ perspectiva da compreensão, os estudantes devem analisar criticamente as informações e ideias para fazer escolhas sensatas e responsáveis a fim de se sair bem, desse modo, esse marco conceitual recomenda avaliações mais autênticas e profundas, com base no desempenho, integradas ao ensino. ${ }^{2}$ 
2. OBJETIVOS 


\section{OBJETIVO GERAL:}

Analisar o desempenho dos estudantes no estágio curricular supervisionado do projeto pedagógico baseado em Competências e dos estudantes do projeto pedagógico na perspectiva do Ensino Para Compreensão.

\subsection{OBJETIVOS ESPECÍFICOS:}

- Identificar a avaliação de desempenho dos estudantes no Estágio Curricular Supervisionado do projeto pedagógico baseado em Competências

- Identificar a avaliação de desempenho dos estudantes no Estágio Curricular Supervisionado do projeto pedagógico na perspectiva do Ensino Para Compreensão

- Comparar a avaliação de desempenho dos estudantes do Estágio Curricular Supervisionado do projeto pedagógico baseado em Competências e dos estudantes do Estágio Curricular Supervisionado do projeto pedagógico na perspectiva do Ensino Para Compreensão.

- Comparar a avaliação de desempenho dos estudantes no estágio curricular supervisionado do projeto pedagógico baseado em Competências e dos estudantes do Estágio Curricular Supervisionado do projeto pedagógico na perspectiva do Ensino Para Compreensão, de acordo com as características de identificação, gênero, idade, formação na área de saúde, ser estudante trabalhador e turno de trabalho. 
3. MATERIAL E MÉTODO 


\section{MATERIAL E MÉTODO:}

Para atingir os objetivos, foi realizado um estudo exploratório descritivo do tipo pesquisa documental por meio da análise dos instrumentos de avaliação dos estudantes da disciplina Estágio Curricular Supervisionado.

A pesquisa documental baseia-se em materiais que ainda não receberam um tratamento analítico ou que podem ser reelaborados com os objetivos da pesquisa. Esse tipo de pesquisa visa selecionar, tratar e interpretar a informação bruta, buscando extrair dela algum sentido e introduzir-Ihe algum valor ${ }^{21}$.

Para tanto, foram utilizados os instrumentos de avaliação de desempenho dos estudantes em campo de prática. Esses instrumentos tiveram sua construção de forma coletiva pelos professores do curso.

São documentos que, ao término de cada estágio, o estudante assina tomando ciência da sua avaliação e ficam arquivados na diretoria do curso.

\subsection{CONTEXTO DO ESTUDO}

O local da pesquisa foi uma Universidade Privada da zona leste do município de São Paulo, e os dados coletados foram os documentos de avaliação de desempenho dos estudantes da disciplina Estágio Curricular Supervisionado do Curso de Graduação em Enfermagem, descrita abaixo:

\subsubsection{Estágio Curricular Supervisionado:}

O Estágio Curricular Supervisionado (ECS) é um componente curricular que acontece nos sétimo e oitavo semestres e deve ter carga horária de vinte por cento do total da carga horária do curso. 
$\mathrm{Na}$ época da coleta de dados a carga horária total do curso era de 3200 horas e, portanto o ECS totalizava 640 horas.

O ECS completa 0 processo ensino-aprendizagem, preparando o estudante para a realidade da profissão. Objetiva diferentes possibilidades de aprendizagem: a realização de experiências práticas para desenvolver a competência de coordenação da assistência de Enfermagem, a inserção do estudante em diferentes contextos de atuação, sua integração às estruturas organizacionais da área da saúde, favorece o envolvimento com a equipe de saúde; proporciona a aplicação de conhecimentos científicos aprendidos, bem como o desenvolvimento de visão crítico reflexiva, de acordo com a realidade prática na qual se insere o Enfermeiro.

Através dos diferentes âmbitos que são vivenciados durante o ECS, este propicia um aprendizado condizente com a prática do profissional de forma reflexiva e crítica dos diferentes níveis de atenção nos quais o enfermeiro insere suas ações. Em todos os campos, as atividades realizadas são supervisionadas por docentes da Universidade.

Todos os estudantes, dos dois currículos, passam por seis campos de ECS, unidade básica de saúde, unidade básica com estratégia de saúde da família, unidade de internação adulto e unidade de internação infantil, unidade de terapia intensiva e estágio de gestão em enfermagem que pode ser em unidade de internação ou unidade ambulatorial.

Cada grupo, de seis a oito estudantes, passa, em média, 20 dias em cada unidade e rodiziam em três destas unidades por semestre. Em um semestre, o rodízio é composto das duas unidades básicas de saúde e da unidade de gestão da assistência. No outro semestre, o rodízio conta com duas unidades de internação e a unidade de terapia intensiva. Esses rodízios foram feitos por 
conveniência do grupo de professores e não existe uma lógica teórica para esta organização.

\subsection{MATERIAL:}

O estudo foi realizado a partir dos seis Instrumentos de avaliação do estágio supervisionado, de cada estudante.

A turma do currículo disciplinar por Competência é composta por 33 estudantes, portanto, a população foi de 198 instrumentos de avaliação. No currículo baseado no ensino para a Compreensão, a turma é composta por 18 estudantes, portanto, 108 instrumentos. No total são 52 estudantes e 312 instrumentos de avaliação; foram incluídos todos os estudantes de cada currículo, não havendo, portanto, critérios de exclusão.

Estes instrumentos de avaliação foram modificados em 2011, ainda na turma do Currículo Disciplinar do Projeto Pedagógico Baseado em Competência que será denominado Currículo $A$, e o Currículo do Projeto Pedagógico na Perspectiva do Ensino para Compreensão, denominado de Currículo B.

Os estudantes do currículo A foram avaliados no segundo semestre de 2011 e no primeiro de 2012 e os estudantes do currículo B foram avaliados nos dois semestres de 2012.

\subsection{PROCEDIMENTO:}

Foi feita a tabulação das notas finais de cada estudante, a tabulação de cada instrumento e posteriormente de cada categoria e suas subcategorias. Para cada um destes campos, o estudante é avaliado pelo professor e para este processo existem três tipos de instrumentos que serão descritos a seguir. 


\subsubsection{Instrumento de avaliação para o estágio na Atenção Básica:}

É composto por quatro bases: comportamentais e atitudinais, conhecimento científico, prática assistências, ações educativas e atividades. (Anexo 3)

Nas Bases Comportamentais, que tem um valor de 0 a 2 pontos, são avaliados os seguintes itens: apresentação pessoal; responsabilidade e compromissos; pontualidade; assiduidade, organização e liderança; postura pessoal e atitudes sociais; construção dos relacionamentos; aceitação das orientações, críticas construtivas e capacidade de assumi-las; identificação de oportunidades de ampliar conhecimento, utilização de material pessoal.

Nas Bases de Conhecimentos Científicos, que têm um valor de 0 a 3 pontos o estudante é avaliado através dos seguintes tópicos: demonstração do conhecimento sobre anatomia/ fisiologia e os processos fisiopatológicos correlacionando com a assistência prestada; reconhecimento da ação dos medicamentos, apresentação, efeitos colaterais, via e forma de administração; correlação dos resultados de exames com a evolução clínica do paciente; iniciativa para reconhecer a dinâmica, fluxos e estrutura da unidade; reconhecimento dos programas de saúde oferecidos pela unidade e pelo SUS; iniciativa em planejar e organizar a unidade; consegue estabelecer prioridades para atender a demanda da unidade e as ações propostas; reconhece e sabe identificar os indicadores epidemiológicos, sanitários e ambientais e realiza notificação compulsória; levanta e analisa dados e informações após visitas domiciliares e/ou em redes de apoio social, propondo ações de saúde; preenche relatórios, livros, fichas específicas de registro e prontuário do paciente de acordo com a rotina da unidade.

Prática Assistencial, que tem valor de 0 a 3 pontos, 0 estudante é avaliado através dos seguintes itens: desenvolve técnicas básicas específicas com conhecimento técnico cientifico; 
informa o estado clínico e reconhece minimamente a complexidade do paciente a fim de orientar e tomar decisões; documenta as ações de forma sistematizada e organizada, com uso de vocabulário e nomenclatura específica às práticas de enfermagem; realiza consulta de enfermagem sistematizada; analisa, discute e avalia a efetividade das ações e práticas de enfermagem prestadas; organiza seu trabalho de maneira que consegue otimizar o seu tempo e suas tarefas; passagem de plantão com informações relevantes e sucintas.

Ações Educativas e Atividades/ Trabalhos, que têm o valor de 0 a 2 pontos, neste tópico o estudante é avaliado através dos itens: propõe a educação em saúde aos usuários e colaboradores da UBS utilizando conteúdo e estratégia de abordagem de acordo com as necessidades da população local, propostas do SUS, da UBS e do professor; realiza busca extra estágio, fazendo pesquisas sobre os assuntos abordados no campo compartilhando com o grupo os conhecimentos adquiridos; desenvolve raciocínio crítico analítico, expondo e debatendo ideias, participa dos debates, traz respostas condizentes; apresentação do trabalho/atividade; tem domínio sobre os dados apresentados; divisão da atividade e trabalho em equipe.

\subsubsection{Instrumento de Avaliação para o Estágio em Unidade de Internação/ UTI:}

Esse instrumento também é composto por quatro grandes grupos de tópicos de avaliação, assim descritos, atitude e comportamento, conhecimento científico, prática assistencial e pesquisa. (Anexo 4)

Atitude e Comportamento, que têm um valor de 0 a 2 pontos, são avaliados os seguintes itens, apresentação pessoal; assiduidade; pontualidade; postura ética; interesse, envolvimento e iniciativa; comunicação verbal e não verbal e escrita; aceitação de orientações e capacidade de assimilá-las; compromissos assumidos 
e cumpridos no prazo estipulado; utilização de material de uso pessoal; capacidade de relacionar-se com o professor, grupo de estágio, profissionais e pacientes.

Conhecimento Científico que tem o valor de 0 a 3 pontos 0 estudante é avaliado através dos seguintes tópicos: demonstra conhecimento sobre anatomia e fisiologia do corpo humano; reconhece o processo fisiopatológico relacionando-os aos sinais clínicos; reconhece os medicamentos em uso quanto à indicação, efeitos colaterais, dosagem e cuidados de enfermagem; realiza a leitura dos exames diagnósticos correlacionando-os com os processos de saúde-doença; participa das visitas clínicas realizadas em cada leito argumentando de maneira adequada a terapêutica instituída de acordo com os processos fisiopatológicos encontrados.

Prática Assistencial valor de 0 a 3 pontos, que tem como itens avaliados o reconhecimento da clientela assistida; reconhece a unidade quanto aos aspectos físicos, materiais e humanos; demonstra habilidade no desenvolvimento de técnicas básicas e especificas, com segurança aos pacientes, de acordo com especificidades da unidade; prática a sistematização da assistência de enfermagem, proposição de soluções adequadas para cada situação; documenta as ações de forma sistematizada e organizada, utilizando terminologia e nomenclatura específica às práticas de enfermagem; demonstra conhecimento e habilidade no desenvolvimento de cuidados especializados aos pacientes com dispositivos invasivos; executa suas tarefas dentro do prazo estipulado, organizando seu tempo de maneira adequada; desenvolve ações de enfermagem segundo critérios e prioridades identificadas; propõe orientações fundamentadas e consistentes aos pacientes e familiares; analisa, discute e avalia a efetividade das ações e práticas de enfermagem prestadas; realiza a passagem de plantão com informações relevantes e objetivas.

Pesquisa, com valor de 0 a 2 pontos, que avalia a realização do estudo de caso dentro da formatação exigida, se o conteúdo do 
trabalho é relevante e atualizado, se a forma de apresentação do trabalho é segura e com domínio do conteúdo; se o estudante propõe reunião em grupo para discussão de assuntos pertinentes à unidade; se a data de entrega foi a estipulada; ampliação das buscas de informação para suprir a necessidade individual e do grupo; identifica a oportunidade de ampliar o conhecimento.

\subsubsection{Instrumento de Avaliação para o Estágio de Gestão:}

Esse instrumento de avaliação é composto por seis categorias como se segue: (Anexo 5)

Atitudinal, que tem um valor de 0 a 1 ponto, são avaliados os seguintes itens, apresentação pessoal; assiduidade; pontualidade; postura ética; interesse, envolvimento e iniciativa; comunicação verbal e não verbal e escrita; aceitação das orientações e capacidade de assimilá-las; compromissos assumidos e cumpridos no prazo estipulado; organização e liderança; capacidade de relacionar-se com o professor, grupo de estágio, profissionais e pacientes.

Gestão de Pessoas, esse tópico tem o valor de 0 a 1,0 pontos, aqui se avalia o estudante nos seguintes aspectos: identifica a distribuição de serviço de acordo com o número de profissionais e o grau de dependência dos pacientes; avalia dos funcionários; promove a integração do paciente e acompanhante à dinâmica hospitalar; realiza orientações fundamentadas e consistentes aos pacientes e familiares; elabora escala mensal com equidade; interage com as equipes multiprofissionais; avalia 0 dimensionamento de pessoas comparando com a legislação vigente.

Gestão de Cuidados, que tem o valor de 0 a 3,0 pontos, os itens avaliados são: identifica o diagnóstico médico e o traduz com explicações plausíveis; reconhece os processos patológicos desencadeados pela doença e presentes no paciente; realiza a sistematização da assistência de enfermagem; realiza levantamento 
de dados através de exame físico, realiza levantamento de dados através do prontuário, propõe diagnósticos de enfermagem, propõe prescrições de enfermagem individualizadas e executáveis, avalia o resultado da aplicação do diagnóstico e da execução da prescrição de enfermagem. Realiza a evolução de enfermagem comparando achados clínicos com melhora, piora ou manutenção do quadro; verifica as anotações nos prontuários: analisa, discute e avalia a efetividade das ações práticas de enfermagem prestada; passa visita diária; passagem de plantão; desenvolve as ações de enfermagem, segundo critérios e prioridades identificadas.

Gestão Administrativa, de 0 a 3 pontos, em que se avalia se 0 estudante atinge os seguintes pontos: Aponta a taxa de ocupação; informa o estado clínico e reconhece minimamente a complexidade do paciente; identifica o número de profissionais disponíveis; consegue identificar e avaliar os dados obtidos através dos indicadores (acidentes de trabalho, queda do paciente, iatrogenias), para definir estratégias e propor soluções; consegue identificar situações problemáticas, avaliar possíveis consequências e propor soluções; liderança: apresenta percepção crítica em relação ao funcionamento da unidade e demonstra capacidade de propor soluções; identifica a necessidade do serviço de limpeza e manutenção dos materiais e equipamentos da unidade de trabalho; elabora e desenvolve projeto voltado para beneficiar o setor ou o serviço de enfermagem.

Gestão Administrativa, com valor de 0 a 1,0 pontos, em que é avaliado se o estudante identifica os impressos utilizados no setor; reconhece relações intersetoriais e fluxo de eventos: laboratório, rouparia, material de consumo, nutrição, farmácia, internação (admissões, transferências e altas); conhece as normas, rotinas e protocolos que envolvem a atividade diária do pessoal de enfermagem (troca de dispositivos de infusão, curativos, remanejamento de pessoal). 
Desenvolvimento Pessoal de 0 a 1,0 pontos, neste item 0 estudante é avaliado pelo desempenho em identificar oportunidades de ampliar conhecimentos; realização de pesquisa sobre assuntos identificados como oportunidades; explicação de dados levantados nos estudos feitos; realização de busca relevante ao cotidiano da unidade; ampliação e busca para suprir as necessidades do grupo.

Todos os instrumentos têm as notas divididas numa escala que engloba atende plenamente, atende parcialmente ou não atende, dividindo assim a nota máxima pelo número de sub escalas e por três, seguindo estes critérios.

A nota do ECS era composta, então, pela soma destes instrumentos. Em cada semestre, o estudante passava por três destes campos, de forma que ele passava pelos seis campos ao término de um ano. $O$ estudante fez o rodízio em qualquer um dos dois formatos e era considerado aprovado o estudante que obtinha uma nota maior ou igual a seis.

Destaca-se que, para campo de prática, havia um professor fixo, o qual avaliava os estudantes dos dois currículos, o que significa que foi o mesmo docente que preencheu os instrumentos de avaliação para os estudantes do currículo A e do currículo B.

\subsection{ASPECTOS ÉTICOS:}

Antes da coleta de dados este projeto foi submetido à apreciação do Comitê de Ética em Pesquisa (CEP), ficando assim em conformidade com a Resolução 196/96 que determina as diretrizes e normas regulamentadoras de pesquisas envolvendo seres humanos.

Consentida a autorização da Universidade para o uso dos documentos (Anexo 6) e um termo de sigilo do pesquisador. (Anexo 7) 


\subsection{ANÁLISE DOS DADOS:}

Os dados provenientes dos instrumentos de avaliação foram tabulados e compuseram o banco de dados, apresentados em tabelas e gráficos descritivos e analisados estatisticamente. Nas variáveis que têm mais de duas opções de resposta foram feitas análise de variância (ANOVA) seguido do método de Tukey, em que foram encontradas diferenças pareadas. Com o item Idade, foi utilizado o coeficiente de correlação de Pearson. Foi utilizado o teste exato de Fisher para comparar as variáveis categóricas e o teste t de student para idade. ${ }^{22}$ 


\section{RESULTADOS E DISCUSS 0}




\section{RESULTADOS E DISCUSSÃO}

Os resultados são apresentados abrangendo a caracterização dos sujeitos, o desempenho dos estudantes e a comparação entre os mesmos.

\subsection{CARACTERIZAÇÃO DOS ESTUDANTES}

Gráfico 1- Número dos estudantes por currículo cursado. São Paulo, 2012.

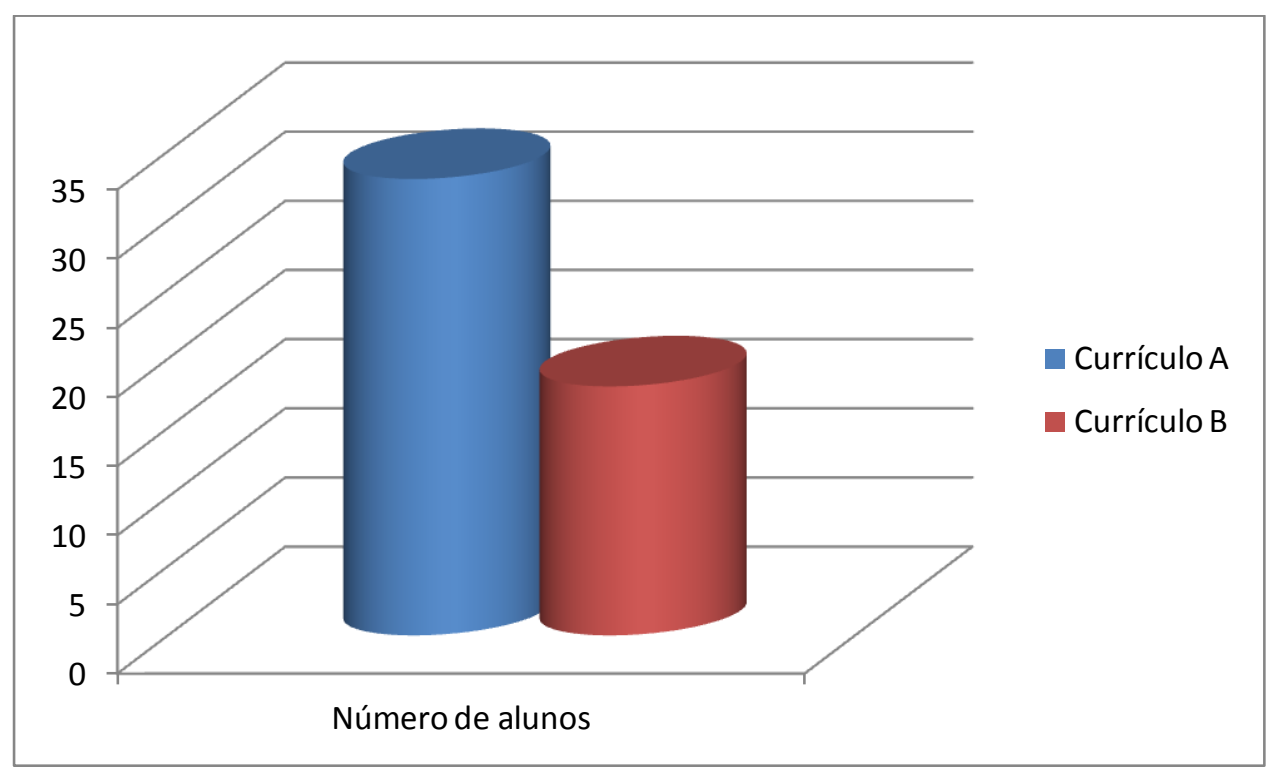

Fonte: Paranhos, WY. Análise do desempenho dos estudantes de enfermagem no ensino por competências e no ensino para compreensão. [tese]. São Paulo: Escola de Enfermagem, Universidade de São Paulo, 2014.

A amostra foi composta por todos os estudantes dos dois currículos, sem critérios de exclusão, 33 estudantes do currículo $A$ e 18 do currículo B. 
Gráfico 2: Gênero dos estudantes por currículo ministrado. São Paulo, 2012

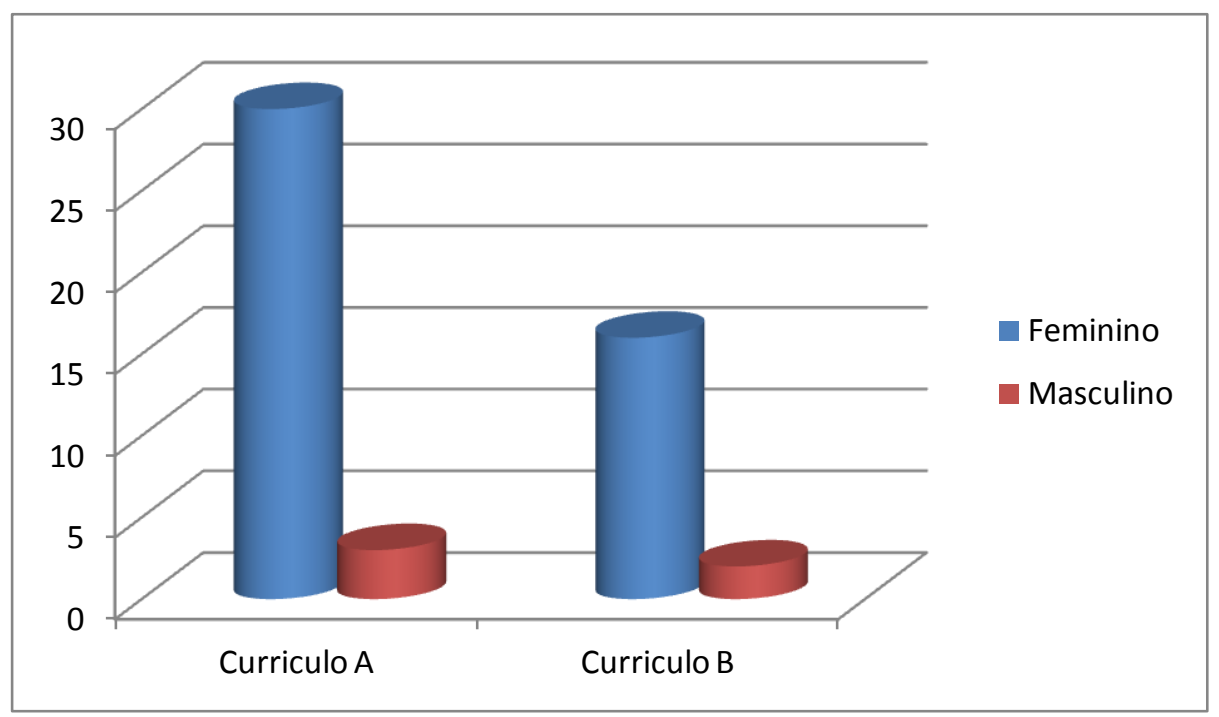

Fonte: Paranhos, WY. Análise do desempenho dos estudantes de enfermagem no ensino por competências e no ensino para compreensão. [tese]. São Paulo: Escola de Enfermagem, Universidade de São Paulo, 2014.

O gráfico um mostra a distribuição por gênero dos estudantes por currículo observa-se que, tanto no $A$ como no $B$, a maioria é de gênero feminino, respectivamente, 30 (90,9\%) e 16 (88,9\%), portanto não há diferença entre os mesmos com relação à variável gênero.

Esse resultado ratifica o contexto histórico da Enfermagem, marcado pelo predomínio da força de trabalho feminina em atividades que envolvem o cuidado, explicitando a relação existente entre o fato de ser mulher e a opção pelos cursos de Enfermagem. Em comparação a outros estudos sobre o gênero dos estudantes de enfermagem, nas diversas instituições estudadas existe 0 predomínio de mulheres. ${ }^{23,24,25}$

A distribuição dos estudantes segundo a idade, esta demonstrado no gráfico três. 
Gráfico 3 - Distribuição da Idade dos estudantes dos currículos A e B. São Paulo, 2012.

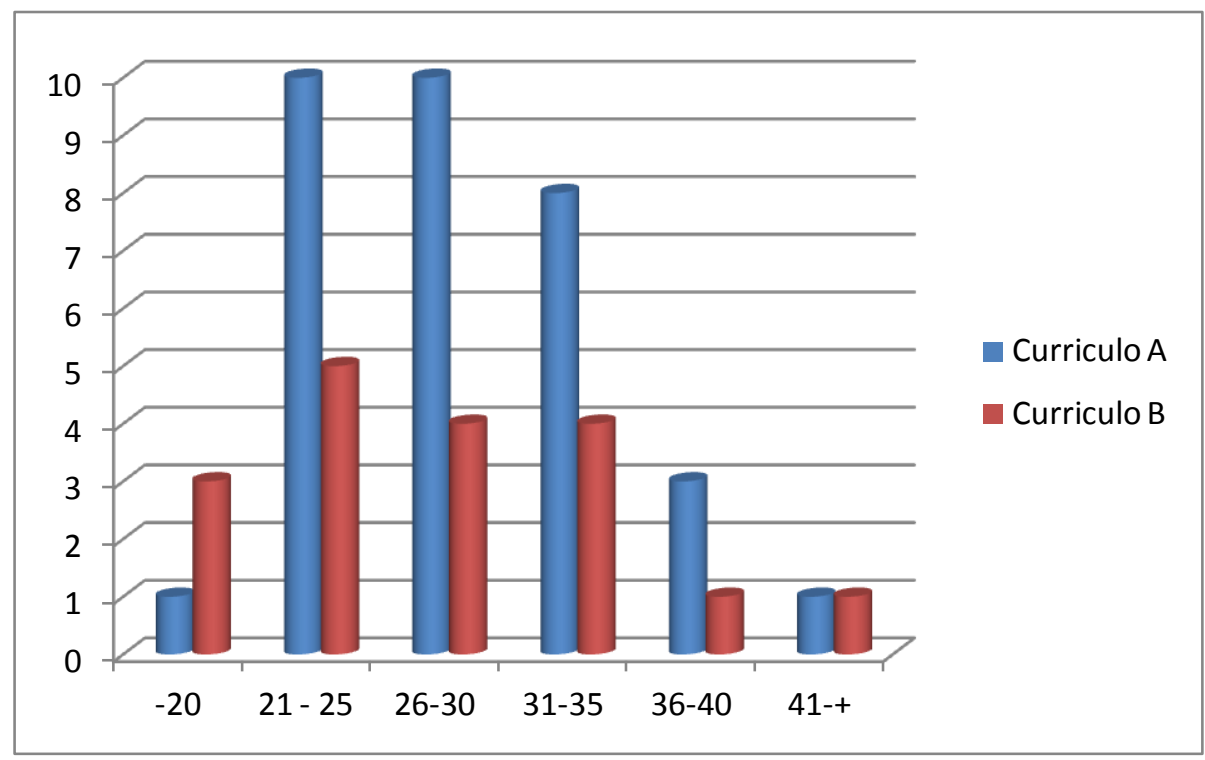

Fonte: Paranhos, WY. Análise do desempenho dos estudantes de enfermagem no ensino por competências e no ensino para compreensão. [tese]. São Paulo: Escola de Enfermagem, Universidade de São Paulo, 2014.

Em relação à idade, foi identificada uma idade média de 28,30 anos (Currículo A) e 28,33 anos (Currículo B). Foi realizado o teste $t$ $(p=0,988)$, que não apontou diferença significativa entre os grupos em relação à variável idade.

Diferente de outros estudos, a faixa etária de predomínio foi de 21 a 30 anos. Os demais estudos possuem predomínio de estudantes na faixa de 18 a 20 anos. ${ }^{23,24,25}$

Essa idade, um pouco superior aos demais estudos, pode interferir na aprendizagem, devido ao fato da maioria deles já ter deixado o ensino médio há algum tempo. Por outro lado, como Santos e Leite ${ }^{25}$ relatam, essa idade pode demonstrar que esses estudantes já têm obrigações familiares e, portanto, devem ter mais interesse e responsabilidade nos estudos.

A distribuição dos estudantes segundo a formação na área de enfermagem está demonstrada no gráfico quatro. 
Gráfico 4 - Distribuição da formação na área de enfermagem dos estudantes dos Currículos A e B. São Paulo, 2012.

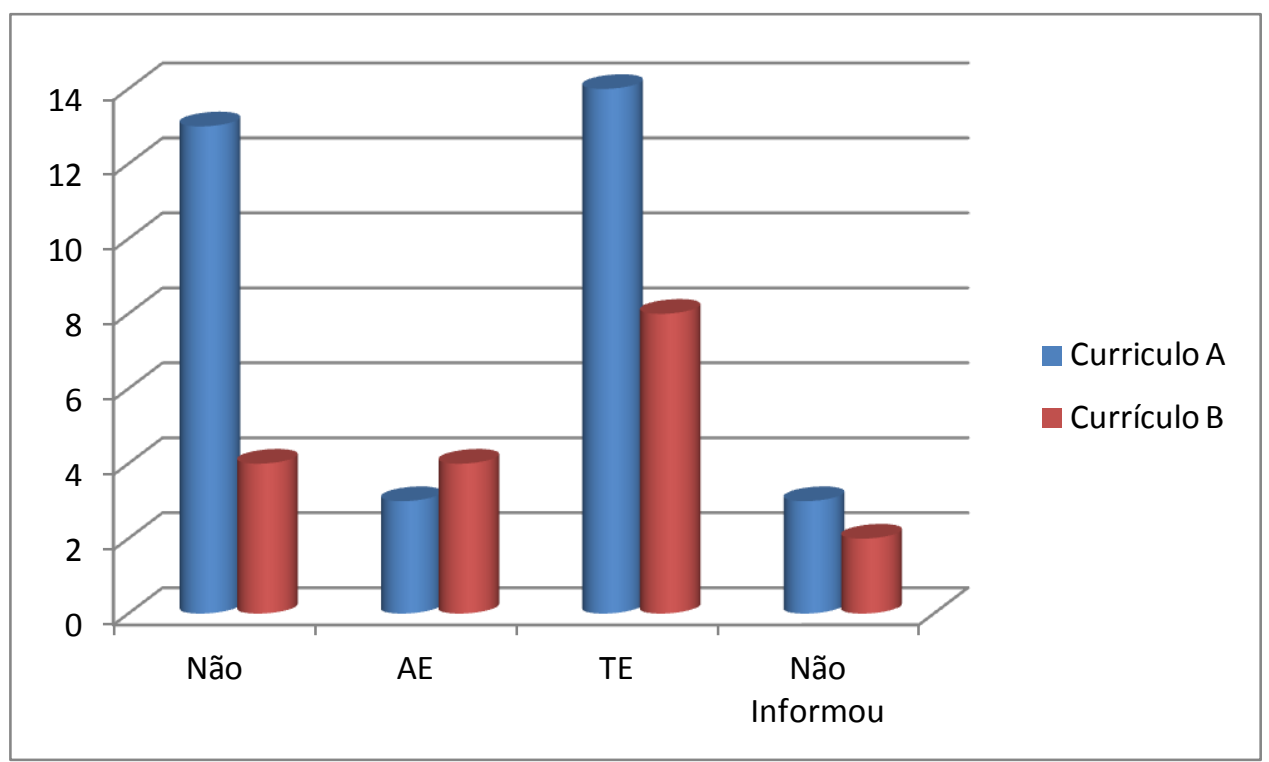

Fonte: Paranhos, WY. Análise do desempenho dos estudantes de enfermagem no ensino por competências e no ensino para compreensão. [tese]. São Paulo: Escola de Enfermagem, Universidade de São Paulo, 2014.

Em relação à formação na área de enfermagem, no Currículo A, 14 estudantes são técnicos de enfermagem (42,42\%), três auxiliares de enfermagem (6,06\%), 13 (39,4\%) não têm formação na área e três $(6,06 \%)$ estudantes não informaram. Dos estudantes do Currículo B, oito são técnicos de enfermagem (44,44\%), quatro são auxiliares de enfermagem (22,22\%), quatro $(22,22 \%)$ não têm formação na área da saúde, e dois não informaram (11,11\%). Portanto, não houve diferença significativa entre os grupos em relação à formação na área de enfermagem.

A predominância de estudantes com formação na área da enfermagem pode ser justificada por buscarem a universidade como uma forma de ascensão na carreira.

A distribuição dos estudantes trabalhadores está demonstrada no gráfico cinco. 
Gráfico 5: Distribuição dos estudantes trabalhadores dos Currículos A e B. São Paulo, 2012.

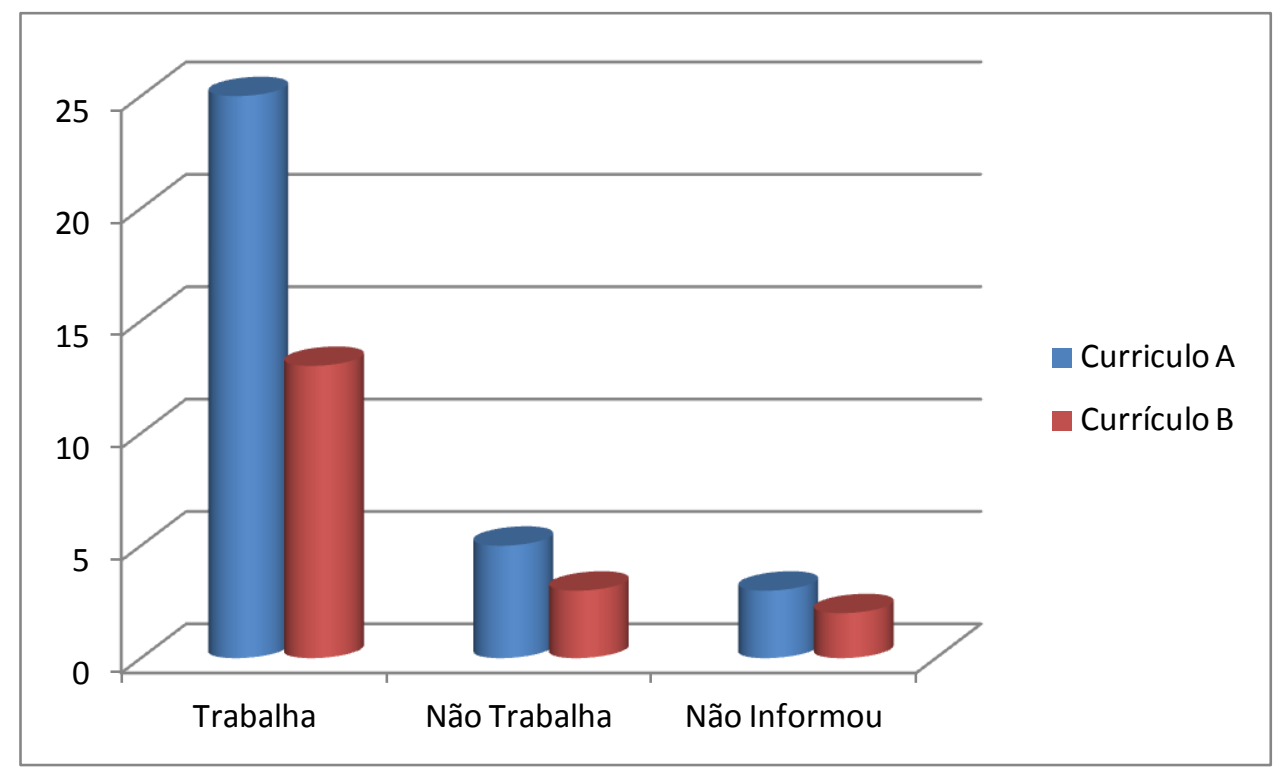

Fonte: Paranhos, WY. Análise do desempenho dos estudantes de enfermagem no ensino por competências e no ensino para compreensão. [tese]. São Paulo: Escola de Enfermagem, Universidade de São Paulo, 2014.

Foram identificados 24 (69,69\%) estudantes trabalhadores do Currículo A, e 13 (72,22\%) estudantes trabalhadores do Currículo B demonstrando que não há diferença entre os grupos em relação à variável ser estudante trabalhador.

Este predomínio de estudantes trabalhadores está em consonância com o dado anterior, onde a maioria tem formação na área da saúde e, portanto, já atuam na área.

Nos últimos anos, o fenômeno "estudante-trabalhador de enfermagem" vem crescendo nos cursos superiores de Enfermagem. A procura parece continuar em franca ascensão, justamente por seduzir o estudante-trabalhador que, altamente motivado, superará grandes desafios para tornar-se enfermeiro. ${ }^{26}$

A distribuição do turno de trabalho dos estudantes pode ser visto no gráfico seis. 
Gráfico 6: Distribuição do turno de trabalho dos estudantes trabalhadores dos currículos $\mathrm{A}$ e $\mathrm{B}$, segundo o turno de trabalho. São Paulo, 2012.

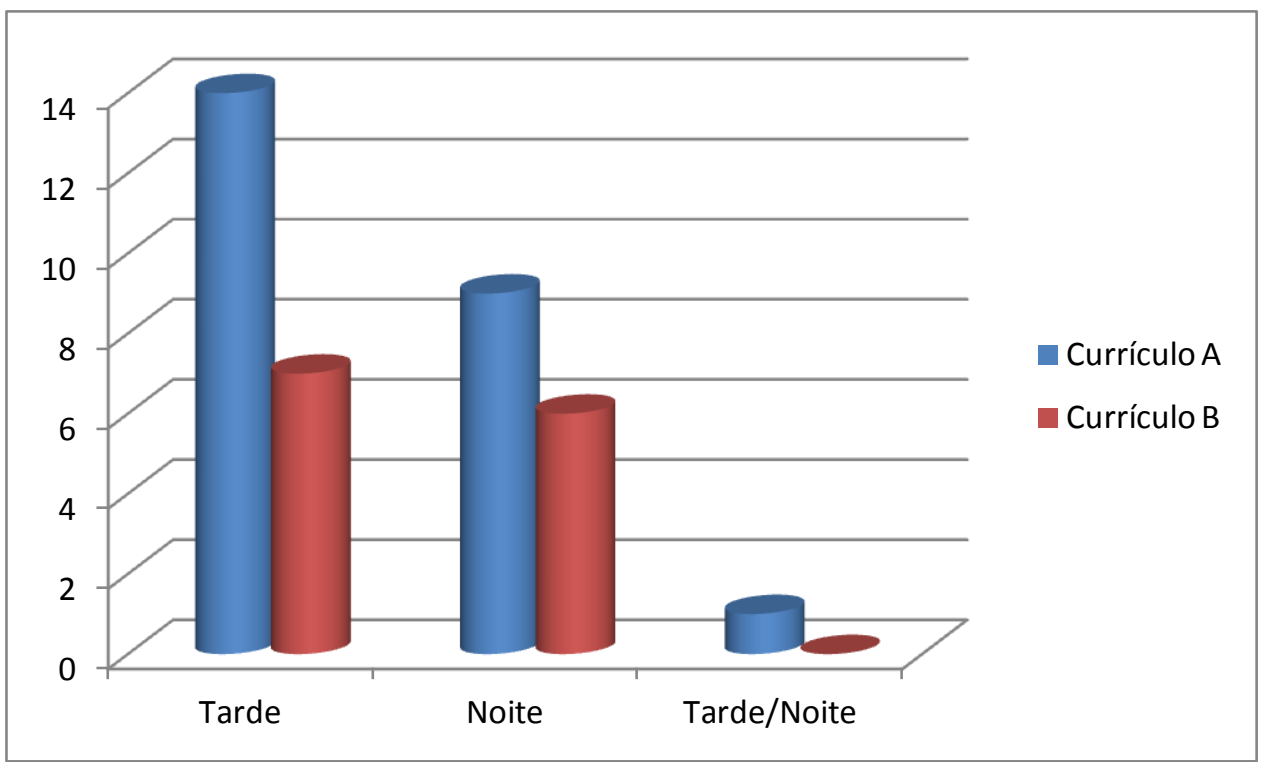

Fonte: Paranhos, WY. Análise do desempenho dos estudantes de enfermagem no ensino por competências e no ensino para compreensão. [tese]. São Paulo: Escola de Enfermagem, Universidade de São Paulo, 2014.

Dos 23 estudantes trabalhadores do currículo A, 14 (58,3\%) trabalham no turno da tarde, nove $(37,5 \%)$ no turno da noite e um $(4,2 \%)$ trabalha em dois turnos, tarde e noite. Dos 13 estudantes que trabalham do currículo $\mathrm{B}$, sete $(53,9 \%)$ trabalham no turno da tarde e seis $(46,1 \%)$ trabalham no turno da noite. Foi realizado o teste exato de Fisher que não mostrou diferença estatística entre os grupos.

\subsection{ANÁLISE DO DESEMPENHO}

A análise do desempenho foi descrita pelos rodízios e categorias do instrumento da avaliação.

A comparação das médias dos currículos A e B pode ser vista no gráfico sete. 
Gráfico 7: Média geral da avaliação de desempenho dos estudantes dos currículos A e B. São Paulo, 2012

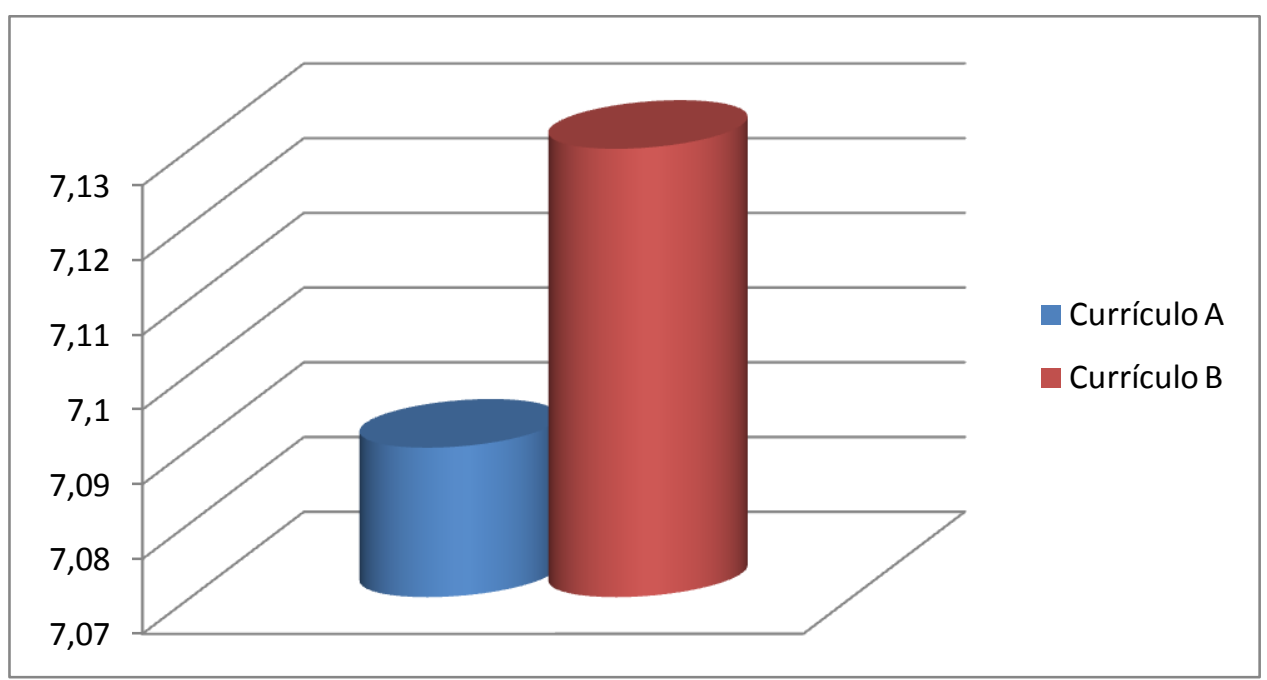

Fonte: Paranhos, WY. Análise do desempenho dos estudantes de enfermagem no ensino por competências e no ensino para compreensão. [tese]. São Paulo: Escola de Enfermagem, Universidade de São Paulo, 2014.

Os estudantes do currículo A tiveram uma média de avaliação de 7,09 e os do currículo B, 7,13, desvio padrão de 0,728 e 0,666 respectivamente. Foi realizado o teste $t,(p=0,985)$, sem diferença significativamente estatística.

No gráfico oito está demonstrada a comparação das médias do desempenho dos estudantes por rodízio. 
Gráfico 8: Médias de avaliação do desempenho dos estudantes por rodízio dos currículos A e B. São Paulo, 2012.

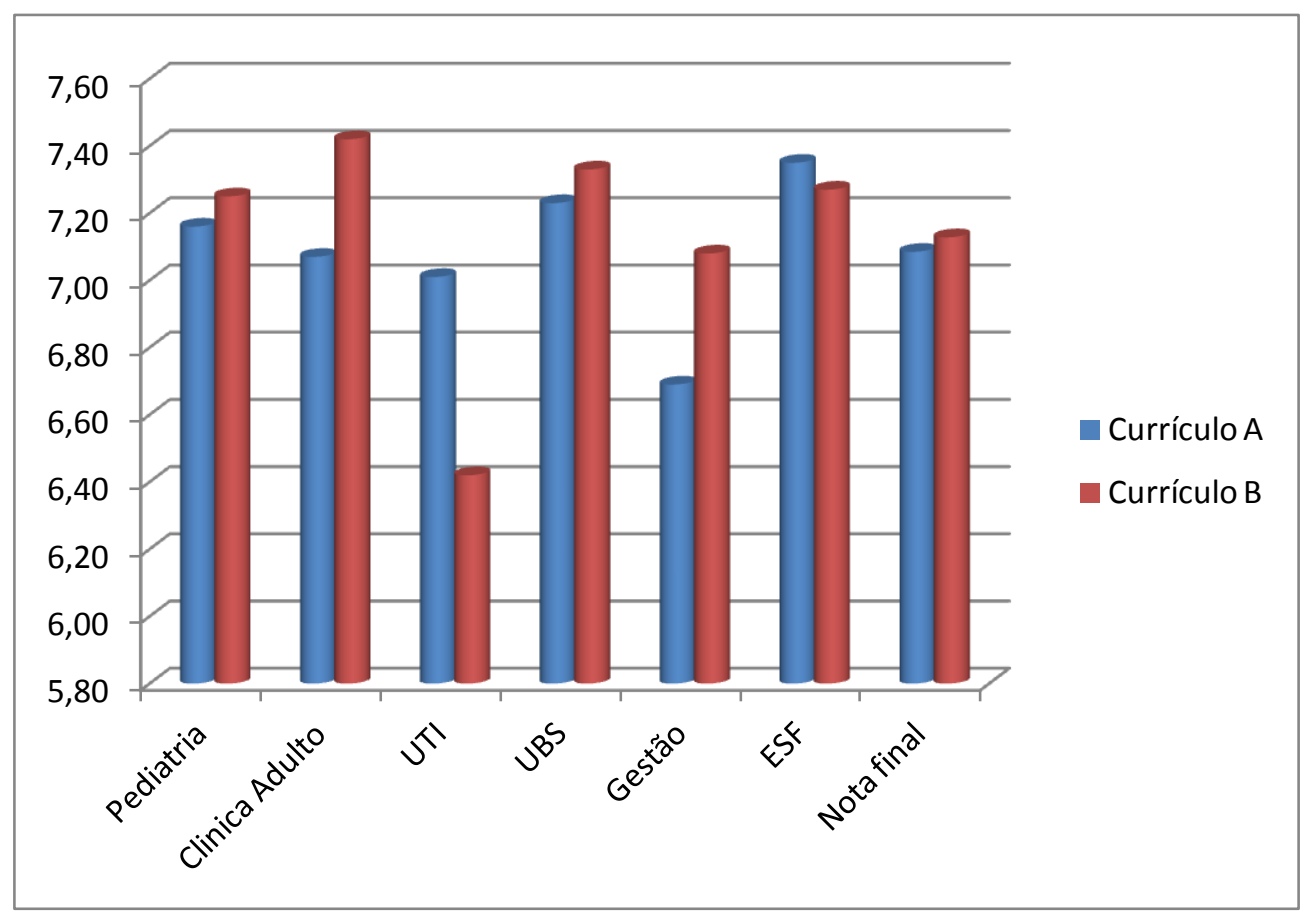

Fonte: Paranhos, WY. Análise do desempenho dos estudantes de enfermagem no ensino por competências e no ensino para compreensão. [tese]. São Paulo: Escola de Enfermagem, Universidade de São Paulo, 2014.

Na pediatria, as médias foram 6,99, com um desvio padrão de 0,933 para o grupo do currículo $A$ e 7,12 com um desvio padrão de 1,014 para o grupo do currículo $B$. Foi realizado o teste $t(p=0,632)$ que não demonstrou diferença entre os grupos.

$\mathrm{Na}$ unidade de internação de pacientes adultos, as médias foram 7,26 pra o currículo A com um desvio padrão de 0,991 e de 7,38 para o currículo $B$ com desvio padrão de 0,725 . O teste $t$ $(0,638)$ não demonstrou diferença estatística.

$\mathrm{Na}$ unidade de terapia intensiva, as médias foram 7,11 para os estudantes do currículo $\mathrm{A}$ com um desvio padrão de 1,088 e, para o currículo $B, 6,44$, com desvio padrão de 1,21 . O teste t $(p=0,46)$ mostrou que a média do grupo do currículo $A$ é maior que a do grupo do currículo B. 
No currículo $A$ esse conteúdo é ministrado na disciplina Enfermagem no ciclo Vital (situações especiais), com 320 horas e aborda assistência nas situações especiais mais prevalentes no ciclo vital. Os objetivos de aprendizagem consistiram em proporcionar ao estudante 0 conhecimento teórico-prático das diferentes especialidades: saúde da mulher, saúde da criança, saúde mental, urgências e emergências e a interação delas no ciclo vital, tendo como enfoque o processo decisório e a intervenção. Ministrada por diversos professores, cada um de cada especialidade.

No currículo B esse conteúdo foi ministrado na UCG Atenção terciária à saúde do indivíduo, família e comunidade, com 160 horas visando desenvolver o raciocínio clínico e o pensamento crítico através do trabalho sistematizado e holístico para atender às necessidades biopsicossociais do indivíduo, família e comunidade, tendo por base conceito de morbimortalidade e princípios de adoecimento em todo o ciclo vital. Os tópicos geradores consistiram em: Sistematização da assistência de enfermagem na saúde da criança, da mulher, em situações de urgências e emergências e saúde mental.

Diante do exposto observa-se que os conteúdos foram os mesmos com metade da carga horária, o que certamente fez com que os professores elegessem um número menor de conteúdo para ministrarem.

Na Unidade Básica de Saúde, com média de 6,89 para os estudantes do currículo $A$ e desvio padrão de 1,053 , e para o currículo $B, 7,23$ com desvio padrão de 0,72 . $O$ teste $t(p=0,166)$ não demonstrou diferença estatística.

Nas unidades de internação e ambulatorial com ênfase na Gestão da assistência de enfermagem, as médias foram de 6,92 para o currículo A, com o desvio padrão de 1,039 e 6,90 para 0 
currículo $B$, com desvio padrão de 0,987 e o teste t $(p=0,945)$ mostrou que não houve diferença estatística.

Na unidade com estratégia de saúde da família, a média dos estudantes do currículo A foi de 7,21 com desvio padrão de 0,851 e a média do currículo $B$ foi de 7,23 com desvio padrão de 0,767 . O teste $\mathrm{t}(\mathrm{p}=0,652)$ não demonstrou diferença estatística entre os grupos. (Apêndice quatro currículo $A$; Apêndice cinco currículo B)

A seguir serão apresentados os resultados do desempenho dos estudantes por meio dos instrumentos de avaliação considerando os rodízios e as categorias do instrumento de avaliação. (Apêndice seis).

Quadro 1: Médias por categorias do instrumento de avaliação, por currículo. São Paulo, 2012.

\begin{tabular}{|l|c|c|c|c|c|}
\hline & \multicolumn{2}{|c|}{$\mathrm{A}(\mathrm{N}=33)$} & \multicolumn{2}{c|}{$\mathrm{B}(\mathrm{N}=18)$} & \\
\hline & Média & DP & Média & DP & Valor-p \\
\hline $\begin{array}{l}\text { Bases Comportamentais } \\
\text { Nota Final - Rodízio 1 }\end{array}$ & 1,763 & 0,105 & 3,181 & 0,271 & 0,000 \\
\hline $\begin{array}{l}\text { Prática Assistencial } \\
\text { Nota Final - Rodízio 3 }\end{array}$ & 2,306 & 0,238 & 2,075 & 0,386 & 0,030 \\
\hline $\begin{array}{l}\text { Desenvolvimento Pessoal } \\
\text { Nota Final - Rodízio 5 }\end{array}$ & 0,733 & 0,173 & 0,867 & 0,301 & 0,048 \\
\hline
\end{tabular}

Fonte: Paranhos, WY. Análise do desempenho dos estudantes de enfermagem no ensino por competências e no ensino para compreensão. [tese]. São Paulo: Escola de Enfermagem, Universidade de São Paulo, 2014.

No quadro um, estão destacadas as categorias que tiveram significância estatística, que foram bases comportamentais com média melhor para os estudantes do currículo $B$, média de 3,181 , desvio padrão de 0,271 e um valor de p no teste de Fisher de 0,0.

Em prática assistencial, os estudantes do currículo $A$ foram melhores que o currículo $B$, com média de 2,306, desvio padrão de 0,238 e um valor $p$ no teste de Fisher de 0,030.

Um dos fatores que pode explicar esse resultado é que os estudantes do Currículo $A$, tiveram mais momentos de aula prática do que os do currículo $B$, nas disciplinas de Instrumentos de 
enfermagem, I, II, III e IV, o que certamente contribuiu para um melhor desempenho nas práticas assistenciais.

No item Desenvolvimento pessoal, os estudantes do currículo B foram melhores que os do currículo $A$, com média de 0,867 e desvio padrão de 0,173, e o valor de p no teste de Fisher de 0,048.

Os estudantes do currículo $\mathrm{B}$, desde o início do curso, no eixo comum da saúde, foram estimulados através de metodologias ativas a ser um elemento ativo no seu aprendizado e isso se reflete nesse item, que exige do estudante pró-atividade. No EPC, o ensino tem ênfase no treinamento de habilidades, desde as mais simples, como leitura, escrita até as mais complexas e de ordem superior como solução de problemas, planejamento, reflexão e avaliação. ${ }^{27}$

Gráfico 9: Distribuição das médias da avaliação de desempenho dos estudantes por categoria do instrumento, dos currículos A e B. São Paulo, 2012.

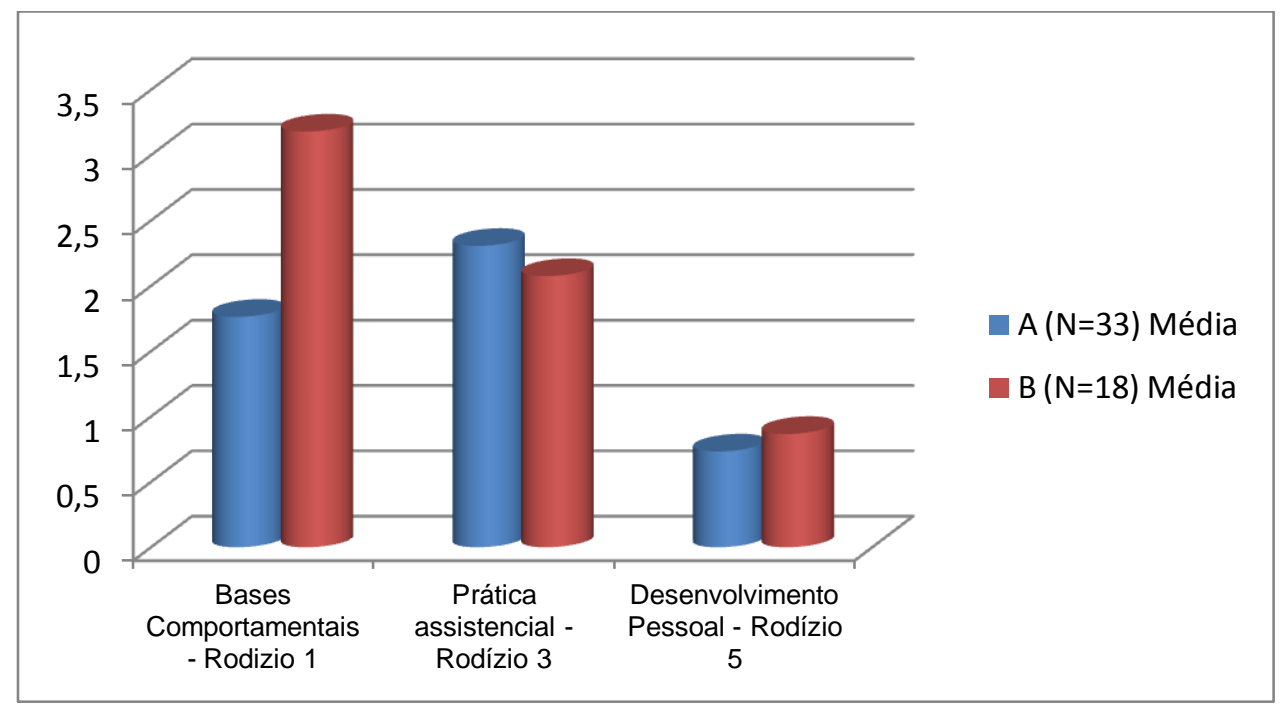

Fonte: Paranhos, WY. Análise do desempenho dos estudantes de enfermagem no ensino por competências e no ensino para compreensão. [tese]. São Paulo: Escola de Enfermagem, Universidade de São Paulo, 2014.

A partir do quadro dois, os resultados são apresentados por rodízio e subcategorias das categorias acima mencionadas. 
No quadro dois, estão demonstradas as subcategorias que tiveram significância estatística no rodízio um (pediatria).

Quadro 2 - Distribuição das notas de avaliação do rodízio um de acordo com o currículo cursado, estatisticamente significante. São Paulo, 2012

\begin{tabular}{|l|l|l|l|l|l|}
\hline \multirow{2}{*}{ Subcategoria } & \multicolumn{2}{|c|}{$\mathrm{A}(\mathrm{n}=33)$} & \multicolumn{2}{c|}{$\mathrm{B}(\mathrm{n}=18)$} & Valor $-\mathrm{p}$ \\
\cline { 2 - 6 } & Média & DP & Média & DV & \\
\hline Apresentação Pessoal & 0,182 & 0,000 & 1,650 & 0,157 & 0,000 \\
\hline $\begin{array}{l}\text { Bases comportamentais } \\
\text { Nota Final }\end{array}$ & 1,763 & 0,105 & 3,181 & 0,271 & 0,000 \\
\hline
\end{tabular}

Fonte: Paranhos, WY. Análise do desempenho dos estudantes de enfermagem no ensino por competências e no ensino para compreensão. [tese]. São Paulo: Escola de Enfermagem, Universidade de São Paulo, 2014.

Gráfico 10 - Distribuição das notas de avaliação do rodízio um de acordo com o currículo cursado. São Paulo, 2012

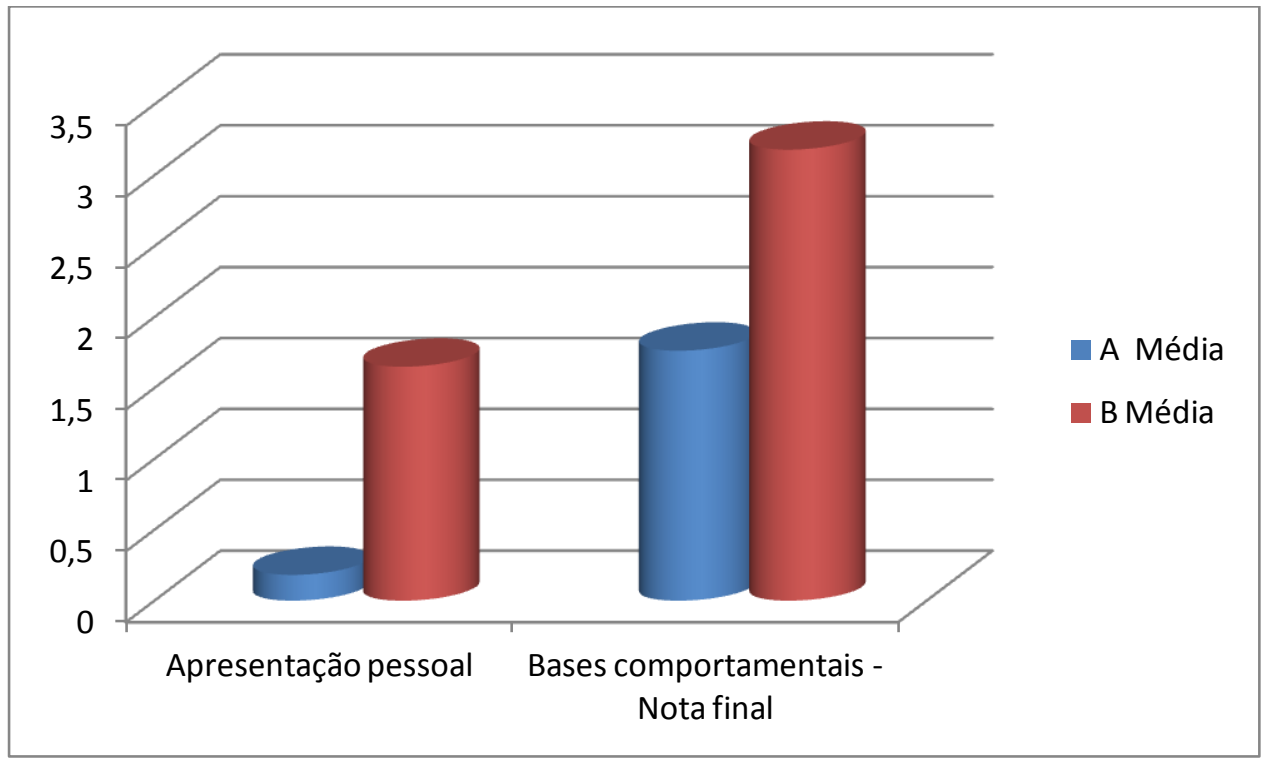

Fonte: Paranhos, WY. Análise do desempenho dos estudantes de enfermagem no ensino por competências e no ensino para compreensão. [tese]. São Paulo: Escola de Enfermagem, Universidade de São Paulo, 2014.

$\mathrm{Na}$ unidade de pediatria, de acordo com o apêndice sete, na maioria das subcategorias não houve significância estatística em relação ao desempenho dos estudantes. No entanto, observa-se que houve diferença na Apresentação Pessoal, uma vez que o teste de Fisher mostrou desempenho melhor dos estudantes do currículo B e nas bases comportamentais nota final, também houve diferença estatística. 
Os estudantes do currículo B tiveram, desde o início do curso, o estímulo para buscar atitudes e comportamentos mais ativos e proativos, pois esse marco conceitual busca ter estudantes mais preocupados com seu comportamento, como já demonstrado por Wiske. ${ }^{2}$

No Quadro três e no Gráfico 11, estão demonstradas as notas do Rodízio dois, unidade de internação adulto, que tiveram diferença estatisticamente significativa.

Quadro 3 - Distribuição das notas de avaliação do rodízio dois de acordo com o currículo cursado, estatisticamente significante. São Paulo, 2012

\begin{tabular}{|l|c|c|c|c|c|}
\hline & \multicolumn{2}{|c|}{$\mathrm{A}(\mathrm{N}=33)$} & \multicolumn{2}{c|}{$\mathrm{B}(\mathrm{N}=18)$} & \\
\hline & Média & DP & Média & DP & Valor-p \\
\hline Uso de Material Pessoal & 0,169 & 0,024 & 0,180 & 0,008 & 0,014 \\
\hline SAE & 0,158 & 0,030 & 0,180 & 0,032 & 0,017 \\
\hline Cuidados Especializados & 0,173 & 0,042 & 0,202 & 0,036 & 0,021 \\
\hline Amplia Conhecimentos & 0,256 & 0,046 & 0,225 & 0,053 & 0,036 \\
\hline
\end{tabular}

Fonte: Paranhos, WY. Análise do desempenho dos estudantes de enfermagem no ensino por competências e no ensino para compreensão. [tese]. São Paulo: Escola de Enfermagem, Universidade de São Paulo, 2014.

Gráfico 11 - Distribuição das notas de avaliação do rodízio dois de acordo com o currículo cursado, estatisticamente significante. São Paulo, 2012

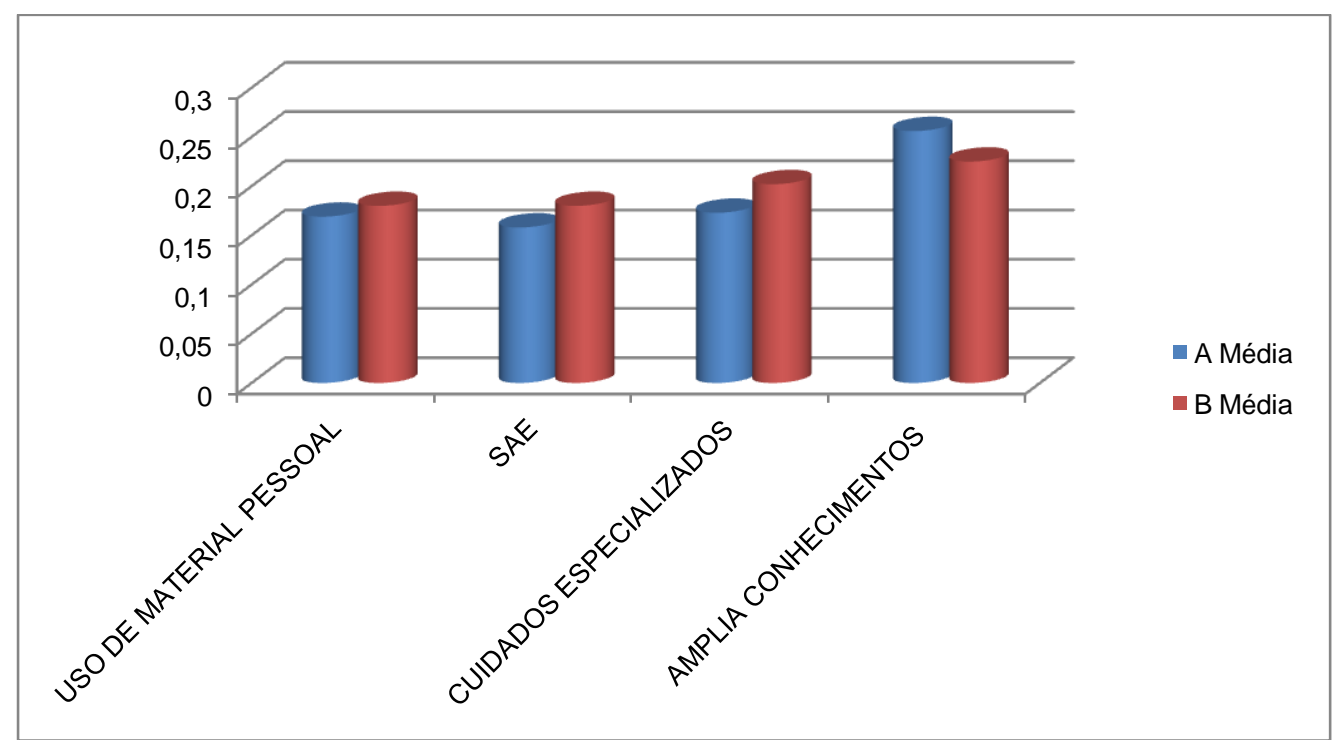

Fonte: Paranhos, WY. Análise do desempenho dos estudantes de enfermagem no ensino por competências e no ensino para compreensão. [tese]. São Paulo: Escola de Enfermagem, Universidade de São Paulo, 2014. 
$\mathrm{Na}$ unidade de internação, de acordo com o apêndice 8, observa-se que os estudantes do currículo A tem nota melhor no item Amplia Conhecimento.

Nos demais itens que apresentam diferença estatística, os estudantes do currículo B apresentam nota melhor. Uso de material pessoal, Sistematização da Assistência de Enfermagem e nos Cuidados Especializados. Conforme demonstrado no quadro quatro, onde o teste de Fisher mostrou diferença.

Esses conteúdos foram abordados no currículo $A$, nas disciplinas de Instrumentos II - procedimentos técnicos de enfermagem com 80 horas, Instrumentos IV- práticas em laboratório da sistematização da assistência de enfermagem com 80 horas e Ciclo Vital (situações prevalentes), com 320 horas.

No currículo B, esses conteúdos foram abordados nas UCGS atenção Secundária à Saúde do Indivíduo Família e Comunidade com $160 \mathrm{~h} / \mathrm{a}$, visava desenvolver o raciocínio e o pensamento crítico através do trabalho sistematizado e holístico para atender às necessidades biopsicossociais do indivíduo, família e comunidade, $\mathrm{t}$ com base nos conhecimentos adquiridos anteriormente, com tópicos geradores - sistematização da assistência de enfermagem na atenção secundária, nos desequilíbrios clínicos crônicos, degenerativos agudos e infecto contagiosas, assistência no processo perioperatório e nas Práticas Profissionais em Semiologia e Semiotécnica com 160 horas, com o tópico gerador procedimentos e técnicas de enfermagem para atendimento das necessidades humanas básicas. Pratica Profissional na Atenção Secundária com 160 horas.

No currículo B, portanto, os estudantes tiveram carga horária maior, o que talvez possa justificar a melhor nota na avaliação de desempenho. 
No quadro quatro e no Gráfico 12, estão demonstradas as subcategorias que tiveram diferença estatística no rodízio três, Unidade de Terapia Intensiva.

Quadro 4 - Notas da avaliação da Unidade de Terapia Intensiva Adulto, de acordo com o currículo cursado, estatisticamente significante. São Paulo, 2012

\begin{tabular}{|l|c|c|c|c|c|}
\hline & \multicolumn{2}{|c|}{$\mathrm{A}(\mathrm{n}=33)$} & \multicolumn{2}{c|}{$\mathrm{B}(\mathrm{n}=18)$} & \\
\hline & Média & $\mathrm{Dp}$ & Média & $\mathrm{Dp}$ & Valor-p \\
\hline Orientação & 0,167 & 0,032 & 0,137 & 0,039 & 0,005 \\
\hline Organização e liderança & 0,144 & 0,043 & 0,114 & 0,045 & 0,023 \\
\hline Visitas & 0,424 & 0,128 & 0,328 & 0,101 & 0,008 \\
\hline Cumpre prazos & 0,223 & 0,057 & 0,184 & 0,065 & 0,034 \\
\hline Efetividade das ações & 0,191 & 0,055 & 0,156 & 0,053 & 0,032 \\
\hline Passagem de plantão & 0,229 & 0,057 & 0,184 & 0,071 & 0,019 \\
\hline $\begin{array}{l}\text { Prática assistencial nota } \\
\text { final }\end{array}$ & 2,306 & 0,238 & 2,075 & 0,386 & 0,030 \\
\hline
\end{tabular}

Fonte: Paranhos, WY. Análise do desempenho dos estudantes de enfermagem no ensino por competências e no ensino para compreensão. [tese]. São Paulo: Escola de Enfermagem, Universidade de São Paulo, 2014.

Gráfico 12 - Distribuição das notas de avaliação do rodízio três de acordo com o currículo cursado, estatisticamente significante. São Paulo, 2012

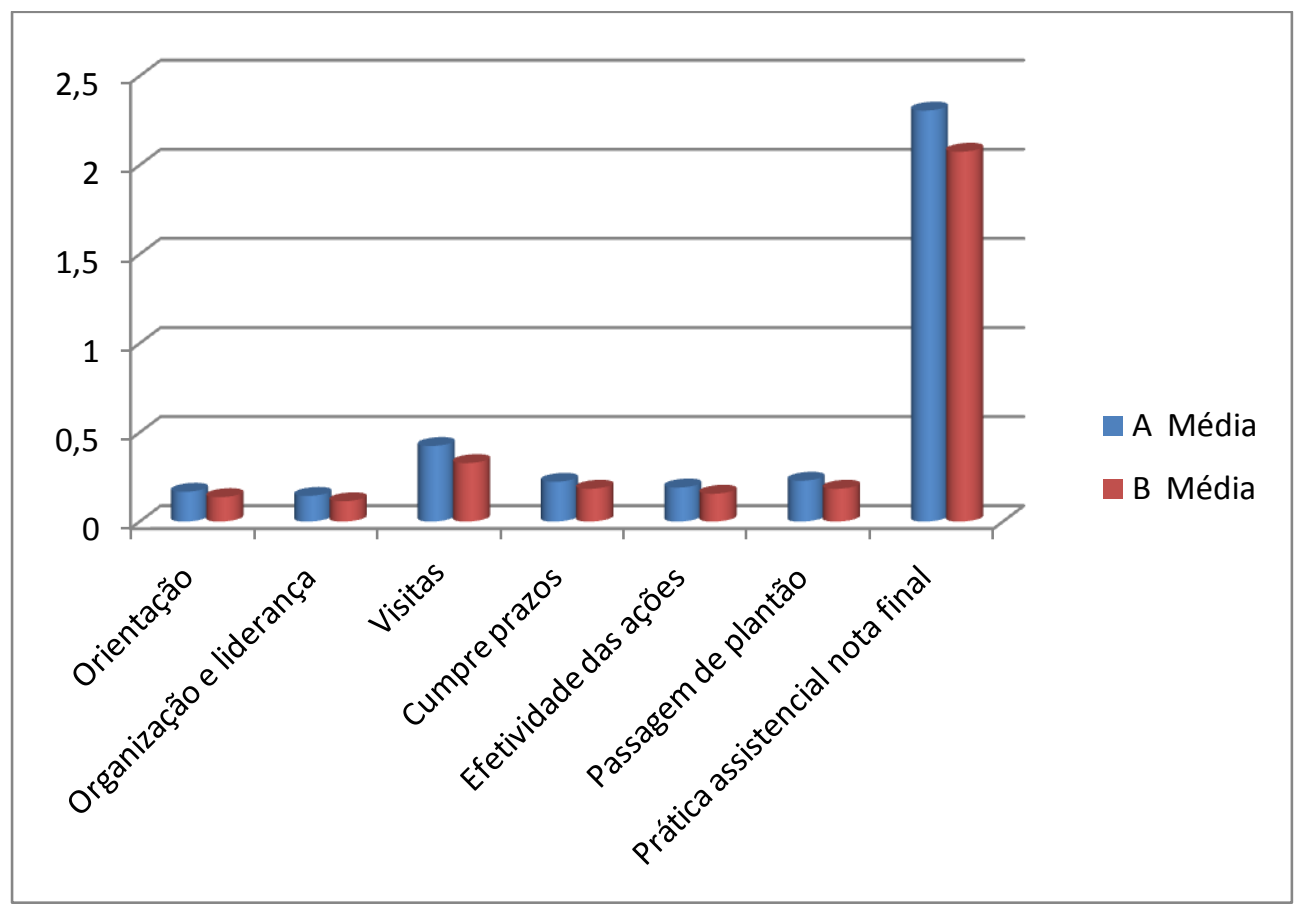

Fonte: Paranhos, WY. Análise do desempenho dos estudantes de enfermagem no ensino por competências e no ensino para compreensão. [tese]. São Paulo: Escola de Enfermagem, Universidade de São Paulo, 2014.

No rodízio três, os estudantes estagiaram em unidade de terapia intensiva de pacientes adultos em um hospital público 
especializado da cidade de São Paulo. E a distribuição de todas as notas de avaliação desse rodízio pode ser vista no apêndice nove.

No quadro quatro, observa-se que os estudantes do Currículo A tiveram nota melhor em todos os itens que tiveram relevância estatística, através do teste de Fisher. Orientação, Organização e Liderança; Visitas; Cumpre Prazos; Efetividade das Ações, Passagem de Plantão. Como já comentado anteriormente, esses conteúdos foram ministrados no currículo $\mathrm{B}$, com metade da carga horária do currículo $\mathrm{A}$.

No quadro cinco e no Gráfico 13 estão demonstradas as notas da avaliação do rodízio quatro, unidade básica de saúde.

Quadro 5 - Notas de avaliação do rodízio quatro de acordo com o currículo cursado, estatisticamente significante. São Paulo, 2012

\begin{tabular}{|l|c|c|c|c|c|}
\hline & \multicolumn{2}{|c|}{$\mathrm{A}(\mathrm{N}=33)$} & \multicolumn{2}{c|}{$\mathrm{B}(\mathrm{N}=18)$} & \\
\hline & Média & $\mathrm{DP}$ & Média & $\mathrm{DP}$ & Valor-p \\
\hline Postura & 0,176 & 0,044 & 0,139 & 0,050 & 0,009 \\
\hline Analisa as Ações & 0,262 & 0,097 & 0,210 & 0,001 & 0,004 \\
\hline Divisão da Atividade & 0,343 & 0,045 & 0,281 & 0,070 & 0,002 \\
\hline
\end{tabular}

Fonte: Paranhos, WY. Análise do desempenho dos estudantes de enfermagem no ensino por competências e no ensino para compreensão. [tese]. São Paulo: Escola de Enfermagem, Universidade de São Paulo, 2014.

Gráfico 13 - Notas de avaliação do rodízio quatro de acordo com o currículo cursado. São Paulo, 2012

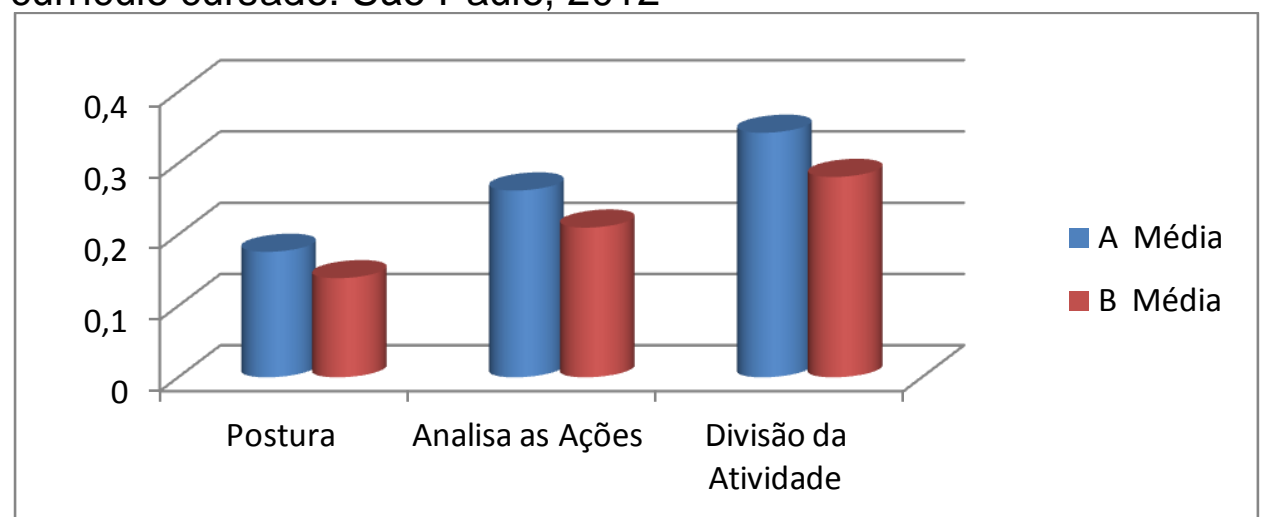

Fonte: Paranhos, WY. Análise do desempenho dos estudantes de enfermagem no ensino por competências e no ensino para compreensão. [tese]. São Paulo: Escola de Enfermagem, Universidade de São Paulo, 2014.

No rodízio quatro, os estudantes estagiaram numa Unidade Básica de Saúde no município de Santo André (SP). No apêndice 10, podemos verificar as notas de avaliação do rodízio quatro, de 
acordo com o currículo cursado. No quadro oito, se observa que em todos os itens de relevância estatística os estudantes do Currículo $\mathrm{A}$ têm notas melhores que os estudantes do currículo $B$, de acordo com o teste de Fisher. Os itens foram: postura, analisa as ações, divisão de atividade.

Esse conteúdo foi ministrado no currículo $A$, nas disciplinas de Contexto Epidemiológico -120h/a, Enfermagem no Ciclo Vital-240 h/a, Educação em Saúde - 80h/a. E no currículo B, nas UCG de Saúde Coletiva com 160h/a, Atenção Primária à Saúde do Indivíduo, Família e Comunidade, também com 160h/a. Também os conteúdos foram ministrados com uma carga horária maior no currículo $A$, o que pode justificar o melhor desempenho.

No quadro seis e no Gráfico 14, estão demonstradas as notas do rodízio cinco, estágio de gestão, que foram estatisticamente significantes.

Quadro 6 - Notas de avaliação do rodízio cinco de acordo com o currículo cursado, estatisticamente significante. São Paulo, 2012

\begin{tabular}{|c|c|c|c|c|c|}
\hline & \multicolumn{2}{|c|}{$\mathrm{A}(\mathrm{N}=33)$} & \multicolumn{2}{c|}{$\mathrm{B}(\mathrm{N}=18)$} & \\
\hline & Média & $\mathrm{DP}$ & Média & $\mathrm{DP}$ & Valor-p \\
\hline Escala Mensal & 0,086 & 0,053 & 0,121 & 0,030 & 0,005 \\
\hline Visita & 0,359 & 0,043 & 0,320 & 0,051 & 0,006 \\
\hline Indicadores & 0,271 & 0,101 & 0,223 & 0,050 & 0,027 \\
\hline $\begin{array}{c}\text { Busca Relevante } \\
\text { Desenvolvimento Pessoal } \\
\text { Nota Final }\end{array}$ & 0,124 & 0,048 & 0,162 & 0,082 & 0,041 \\
\hline
\end{tabular}

Fonte: Paranhos, WY. Análise do desempenho dos estudantes de enfermagem no ensino por competências e no ensino para compreensão. [tese]. São Paulo: Escola de Enfermagem, Universidade de São Paulo, 2014. 
Gráfico 14 - Distribuição das notas de avaliação do rodízio cinco de acordo com o currículo cursado. São Paulo, 2012

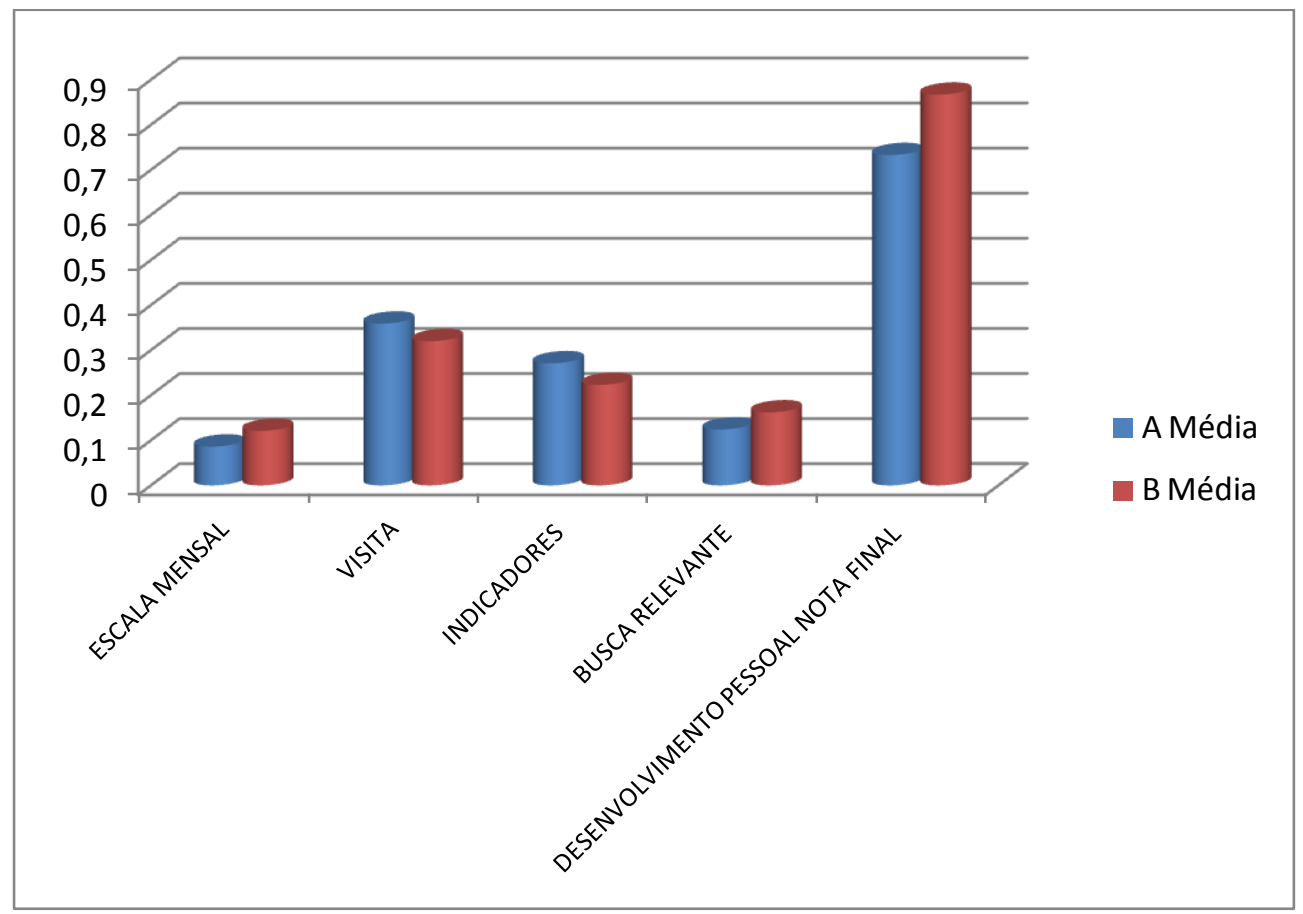

Fonte: Paranhos, WY. Análise do desempenho dos estudantes de enfermagem no ensino por competências e no ensino para compreensão. [tese]. São Paulo: Escola de Enfermagem, Universidade de São Paulo, 2014.

No Rodízio cinco, os estudantes estagiaram em unidade de internação e ambulatorial no estágio de gestão. As notas de avaliação desse rodízio de acordo com o currículo cursado podem ser vistas no apêndice 11.

No Quadro seis verificamos que os estudantes do currículo B têm notas melhores que os do currículo A no item de elaborar escala mensal e também nas buscas relevantes e na nota final do desenvolvimento pessoal. O currículo A tem notas melhor que os do Currículo B na passagem de visita e análise dos indicadores.

No quadro sete e no gráfico 15 estão demonstradas as notas do rodízio seis, unidade básica com estratégia de saúde da família. 
Quadro 7 - Notas de avaliação do rodízio seis de acordo com o currículo cursado, estatisticamente significante. São Paulo, 2012

\begin{tabular}{|c|c|c|c|c|c|}
\hline & \multicolumn{2}{|c|}{$\mathrm{A}(\mathrm{N}=33)$} & \multicolumn{2}{c|}{$\mathrm{B}(\mathrm{N}=18)$} & \\
\hline & Média & $\mathrm{DP}$ & Média & $\mathrm{DP}$ & Valor-p \\
\hline Material de Uso Pessoal & 0,173 & 0,045 & 0,192 & 0,019 & 0,042 \\
\hline Organização e Liderança & 0,132 & 0,046 & 0,160 & 0,023 & 0,006 \\
\hline Preenche Relatórios & 0,275 & 0,055 & 0,242 & 0,051 & 0,039 \\
\hline
\end{tabular}

Fonte: Paranhos, WY. Análise do desempenho dos estudantes de enfermagem no ensino por competências e no ensino para compreensão. [tese]. São Paulo: Escola de Enfermagem, Universidade de São Paulo, 2014.

Gráfico 15 - Notas de avaliação do rodízio seis de acordo com o currículo cursado, estatisticamente significante. São Paulo, 2012

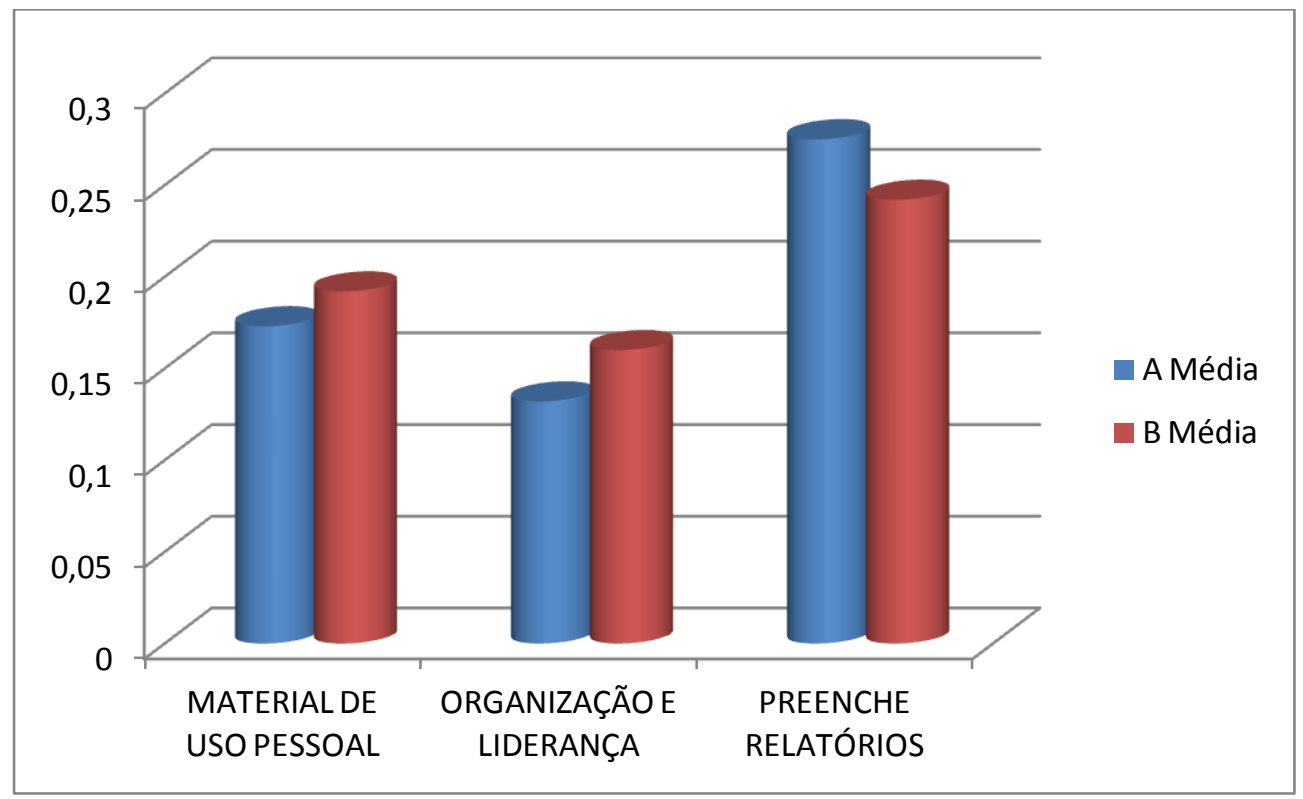

Fonte: Paranhos, WY. Análise do desempenho dos estudantes de enfermagem no ensino por competências e no ensino para compreensão. [tese]. São Paulo: Escola de Enfermagem, Universidade de São Paulo, 2014.

No rodízio seis, os estudantes estagiaram em unidade com estratégia de saúde da família no município de Santo André. A distribuição das notas de avaliação do rodízio seis de acordo com o currículo cursado pode ser vista no Apêndice 12.

No quadro sete, observa-se a distribuição das notas de avaliação do rodízio seis de acordo com o currículo cursado, estatisticamente significante. Os itens com significância foram: material de uso pessoal, organização e liderança; preenche relatórios. 
Os estudantes do currículo $A$ tem notas melhores que os estudantes do currículo $B$ no item preenche relatório e o Currículo $B$ têm notas melhores nos itens organização e liderança e material de uso pessoal.

Os estudantes do currículo B desde o inicio da graduação são estimulados a trabalhos em grupo e também tiveram a experiência de trabalho em equipe no primeiro ano do curso e conviveram com os estudantes dos outros cursos da área da saúde.

\subsection{COMPARAÇÃO DO DESEMPENHO DOS ESTUDANTES DE ACORDO COM AS VARIÁVEIS DE IDENTIFICAÇÃO:}

Avaliação do desempenho dos estudantes por rodízio, subcategorias do instrumento de avaliação, e variáveis como idade, gênero, formação na área da saúde e turno de trabalho.

Nesse quadro, quando a correlação é positiva, o aluno mais velho tem desempenho melhor, e quando a correlação é negativa o aluno mais jovem tem desempenho melhor.

Quadro 8 : Comparação do desempenho dos estudantes com relação à idade. São Paulo, 2012

\begin{tabular}{|c|c|c|}
\hline & Correlação & Valor-p \\
\hline Uso de Material Pessoal - Rodízio 1 & 0,293 & 0,037 \\
\hline Técnica - Rodízio 1 & 0,358 & 0,010 \\
\hline Cuidados Especializados - Rodízio 1 & 0,353 & 0,011 \\
\hline Amplia Conhecimento - Rodízio 2 & 0,332 & 0,017 \\
\hline Interesse - Rodízio 3 & 0,298 & 0,034 \\
\hline Cumpre Prazos - Rodízio 3 & 0,282 & 0,045 \\
\hline Construção de Relacionamentos - Rodízio 4 & $-0,304$ & 0,030 \\
\hline Interesse - Rodízio 4 & 0,363 & 0,009 \\
\hline Anatomia e Fisiologia - Rodízio 4 & 0,325 & 0,020 \\
\hline Medicamentos - Rodízio 4 & 0,302 & 0,031 \\
\hline Assiduidade - Rodízio 5 & 0,277 & 0,049 \\
\hline Relacionamento - Rodízio 5 & $-0,284$ & 0,044 \\
\hline Escala Mensal - Rodízio 5 & $-0,292$ & 0,037 \\
\hline Interesse - Rodízio 6 & 0,341 & 0,014 \\
\hline Relaciona Exames - Rodízio 6 & 0,283 & 0,044 \\
\hline Passagem de Plantão - Rodízio 6 & 0,286 & 0,042 \\
\hline Educação em Saúde - Rodízio 6 & 0,443 & 0,001 \\
\hline Raciocínio Critico - Rodízio 6 & 0,520 & 0,000 \\
\hline
\end{tabular}

Fonte: Paranhos, WY. Análise do desempenho dos estudantes de enfermagem no ensino por competências e no ensino para compreensão. [tese]. São Paulo: Escola de Enfermagem, Universidade de São Paulo, 2014. 
$\mathrm{Na}$ maioria dos itens, os estudantes mais velhos tiveram um desempenho melhor que os mais jovens.

As subcategorias que os mais velhos foram melhores são: No Rodízio Um: Uso de material pessoal, Técnica, Cuidados Especializados. No Rodízio Dois: Amplia Conhecimento. No Rodízio Três: Interesse, Cumpre Prazos. No Rodízio Quatro: Interesse, Anatomia e Fisiologia Medicamentos. No Rodízio Cinco: Assiduidade, Relacionamento, Escala Mensal. No Rodízio Seis: Interesse, Relaciona Exames, Passagem de plantão, Educação em Saúde, Raciocínio Crítico. O quadro com todas as correlações de idade pode ser visto no apêndice 13.

Aqui podemos discutir várias hipóteses, a primeira é que a maioria dos estudantes mais velhos são os que já têm formação na área da saúde que será discutido mais a frente. Outra hipótese é que o estudante mais velho, diferente do que se possa imaginar, apesar de mais tempo fora dos estudos ele tem mais responsabilidade e paga pelo seu próprio estudo, o que justifica seu maior empenho e consequente melhor desempenho. ${ }^{24}$

No quadro nove, está demonstrada a comparação das subcategorias com o gênero dos estudantes. 
Quadro 9: Comparação das subcategorias que demonstraram diferença estatística, quando comparado o gênero do estudante.São Paulo, 2012.

\begin{tabular}{|c|c|c|c|c|c|}
\hline 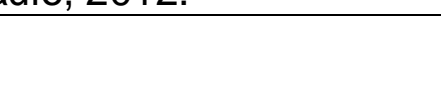 & \multicolumn{2}{|c|}{$\begin{array}{l}\text { Feminino } \\
(\mathrm{N}=47)\end{array}$} & \multicolumn{2}{|c|}{$\begin{array}{l}\text { Masculino } \\
(\mathrm{N}=4)\end{array}$} & \\
\hline & Média & $\mathrm{DP}$ & Média & DP & Valor-P \\
\hline Compromisso - Rodízio 1 & 0,169 & 0,024 & 0,182 & 0,000 & 0,001 \\
\hline $\begin{array}{l}\text { Uso de Material Pessoal - } \\
\text { Rodízio } 1\end{array}$ & 0,171 & 0,021 & 0,147 & 0,026 & 0,032 \\
\hline Amplia a Busca - Rodízio 1 & 0,203 & 0,040 & 0,175 & 0,000 & 0,000 \\
\hline $\begin{array}{l}\text { Uso de Material Pessoal - } \\
\text { Rodízio } 3\end{array}$ & 0,170 & 0,026 & 0,182 & 0,000 & 0,002 \\
\hline Trabalhos - Rodízio 2 & 0,248 & 0,052 & 0,286 & 0,000 & 0,000 \\
\hline Reunião - Rodízio 2 & 0,254 & 0,047 & 0,203 & 0,056 & 0,046 \\
\hline Entrega - Rodízio 2 & 0,268 & 0,040 & 0,286 & 0,000 & 0,004 \\
\hline $\begin{array}{l}\text { Uso de Material Pessoal - } \\
\text { Rodízio } 3\end{array}$ & 0,170 & 0,026 & 0,182 & 0,000 & 0,002 \\
\hline Trabalhos - Rodízio 3 & 0,193 & 0,061 & 0,123 & 0,061 & 0,031 \\
\hline $\begin{array}{l}\text { Assiduidade - } \\
\text { Rodízio } 4\end{array}$ & 0,163 & 0,047 & 0,193 & 0,015 & 0,016 \\
\hline Estado Clinico - Rodízio 4 & 0,331 & 0,105 & 0,238 & 0,055 & 0,030 \\
\hline $\begin{array}{l}\text { Educação em Saúde - } \\
\text { Rodízio } 4\end{array}$ & 0,314 & 0,067 & 0,238 & 0,078 & 0,034 \\
\hline $\begin{array}{l}\text { Interesse - } \\
\text { Rodízio } 5\end{array}$ & 0,086 & 0,019 & 0,059 & 0,026 & 0,008 \\
\hline $\begin{array}{l}\text { Materiais Permanentes - } \\
\text { Rodízio } 5\end{array}$ & 0,182 & 0,041 & 0,163 & 0,000 & 0,003 \\
\hline $\begin{array}{l}\text { Amplia Conhecimento - } \\
\text { Rodízio } 5\end{array}$ & 0,184 & 0,029 & 0,146 & 0,048 & 0,021 \\
\hline Postura - Rodízio 6 & 0,177 & 0,045 & 0,200 & 0,000 & 0,001 \\
\hline Interesse - Rodízio 6 & 0,182 & 0,033 & 0,143 & 0,051 & 0,035 \\
\hline $\begin{array}{l}\text { Organiza o Trabalho - } \\
\text { Rodízio } 6\end{array}$ & 0,372 & 0,085 & 0,263 & 0,075 & 0,016 \\
\hline
\end{tabular}

Fonte: Paranhos, WY. Análise do desempenho dos estudantes de enfermagem no ensino por competências e no ensino para compreensão. [tese]. São Paulo: Escola de Enfermagem, Universidade de São Paulo, 2014.

Foi realizado o teste exato de Fisher para comparar o gênero dos estudantes.

Os estudantes tiveram melhores notas no rodízio da unidade de pediatria nos itens Compromisso. E na unidade de terapia intensiva: Uso de Material Pessoal, Assiduidade, Postura. As estudantes são melhores no rodízio de pediatria: Uso de Material Pessoal. No rodízio 3: Trabalhos. No rodízio de unidade básica de saúde: Estado Clínico e Educação em Saúde. No estágio de Gestão: Interesse, Materiais Permanentes e Amplia Conhecimento. $\mathrm{Na}$ unidade com estratégia de saúde da família: Interesse e Organiza o Trabalho. Todos os dados podem ser vistos no apêndice 14 . 
Esse dado confirma as hipóteses anteriores, a maioria dos estudantes é do gênero feminino, mais velha e já atua na área da saúde como técnica de enfermagem.

No quadro 10, estão demonstradas a comparação do desempenho dos estudantes com relação à formação na área de enfermagem.

Quadro 10: Comparação da avaliação de desempenho dos estudantes, nas subcategorias, em relação à formação área da enfermagem. São Paulo, 2012

(continua)

\begin{tabular}{|l|c|c|c|}
\hline & \multicolumn{3}{|c|}{ Valor-P } \\
\hline & $\begin{array}{c}\text { Auxiliar X } \\
\text { Técnico }\end{array}$ & $\begin{array}{c}\text { Auxiliar X } \\
\text { Outro }\end{array}$ & $\begin{array}{c}\text { Técnico X } \\
\text { Outro }\end{array}$ \\
\hline Comunicação - Rodízio 1 & 0,961 & 0,169 & 0,015 \\
\hline Medicamentos - Rodízio 1 & 0,671 & 0,424 & 0,015 \\
\hline Técnica - Rodízio 1 & 0,200 & 0,245 & 0,000 \\
\hline Cuidados Especializados - Rodízio 1 & 0,262 & 0,067 & 0,000 \\
\hline Ações de Enfermagem - Rodízio 1 & 0,484 & 0,726 & 0,031 \\
\hline Efetividade das Ações - Rodízio 1 & 0,028 & 0,439 & 0,148 \\
\hline Passagem de Plantão - Rodízio 1 & 0,342 & 0,960 & 0,066 \\
\hline Comunicação - Rodízio 2 & 0,961 & 0,169 & 0,015 \\
\hline Anatomia e Fisiologia - Rodízio 2 & 0,174 & 0,062 & 0,000 \\
\hline Fisiopatologia - Rodízio 2 & 0,404 & 0,020 & 0,000 \\
\hline Medicamentos - Rodízio 2 & 0,769 & 0,002 & 0,000 \\
\hline Exames - Rodízio 2 & 0,993 & 0,001 & 0,000 \\
\hline Visitas- Rodízio 2 & 0,505 & 0,080 & 0,000 \\
\hline Reconhece a Clientela - Rodízio 2 & 0,586 & 0,155 & 0,001 \\
\hline Técnica - Rodízio 2 & 0,488 & 0,037 & 0,000 \\
\hline SAE- Rodízio 2 & 0,602 & 0,075 & 0,000 \\
\hline Documenta - Rodízio 2 & 0,550 & 0,085 & 0,000 \\
\hline Cuidados Especializados - Rodízio 2 & 0,554 & 0,020 & 0,000 \\
\hline Cumpre Prazos - Rodízio 2 & 0,684 & 0,068 & 0,000 \\
\hline Ações de Enfermagem - Rodízio 2 & 0,513 & 0,153 & 0,000 \\
\hline Orientações - Rodízio 2 & 0,780 & 0,060 & 0,000 \\
\hline Efetividade das Ações - Rodízio 2 & 0,507 & 0,146 & 0,000 \\
\hline Passagem de Plantão - Rodízio 2 & 0,682 & 0,337 & 0,009 \\
\hline Reunião - Rodízio 2 & 0,038 & 0,179 & 0,612 \\
\hline Fisiopatologia - Rodízio 3 & 0,902 & 0,224 & 0,015 \\
\hline Unidade - Rodízio 3 & 0,481 & 0,360 & 0,941 \\
\hline Documenta - Rodízio 3 & 0,026 & 0,484 & 0,111 \\
\hline Ações de Enfermagem - Rodízio 3 & 0,013 & 0,211 & 0,233 \\
\hline Domínio do Conteúdo - Rodízio 3 & 0,105 & 0,886 & 0,003 \\
\hline Amplia Conhecimento - Rodízio 3 & 0,039 & 0,135 & 0,748 \\
\hline
\end{tabular}


(continuação)

\begin{tabular}{|c|c|c|c|}
\hline & \multicolumn{3}{|c|}{ Valor-P } \\
\hline & $\begin{array}{l}\text { Auxiliar X } \\
\text { Técnico }\end{array}$ & $\begin{array}{l}\text { Auxiliar X } \\
\text { Outro }\end{array}$ & $\begin{array}{l}\text { Técnico X } \\
\text { Outro }\end{array}$ \\
\hline Interesse - Rodízio 4 & 0,285 & 0,038 & 0,327 \\
\hline Medicamentos - Rodízio 4 & 0,533 & 0,295 & 0,003 \\
\hline Documenta as Ações - Rodízio 4 & 0,427 & 0,010 & 0,038 \\
\hline Organiza o Trabalho - Rodízio 4 & 0,225 & 0,545 & 0,001 \\
\hline Passagem de Plantão - Rodízio 4 & 0,759 & 0,489 & 0,037 \\
\hline Avalia Funcionários - Rodízio 5 & 0,997 & 0,682 & 0,426 \\
\hline Promove Integração - Rodízio 5 & 0,712 & 0,129 & 0,001 \\
\hline $\begin{array}{l}\text { Gestão De Cuidados Nota Final - } \\
\text { Rodízio } 5\end{array}$ & 0,280 & 1,000 & 0,096 \\
\hline Indicadores - Rodízio 5 & 0,270 & 0,515 & 0,002 \\
\hline Problemas - Rodízio 5 & 0,367 & 0,757 & 0,018 \\
\hline Liderança - Rodízio 5 & 0,940 & 0,276 & 0,032 \\
\hline $\begin{array}{l}\text { Gestão Administrativa } 1 \text { Nota Final - } \\
\text { Rodízio } 5\end{array}$ & 0,680 & 0,370 & 0,011 \\
\hline Impressos - Rodízio 5 & 0,990 & 0,189 & 0,029 \\
\hline $\begin{array}{l}\text { Gestão Administrativa } 2 \text { Nota Final - } \\
\text { Rodízio } 5\end{array}$ & 0,879 & 0,346 & 0,033 \\
\hline Busca Relevante - Rodízio 5 & 0,603 & 0,034 & 0,069 \\
\hline Orientação - Rodízio 6 & 0,041 & 0,087 & 0,918 \\
\hline Interesse - Rodízio 6 & 0,127 & 0,251 & 0,889 \\
\hline Anatomia E Fisiologia - Rodízio 6 & 0,238 & 0,941 & 0,027 \\
\hline Média Final & 0,131 & 0,672 & 0,001 \\
\hline
\end{tabular}

Fonte: Paranhos, WY. Análise do desempenho dos estudantes de enfermagem no ensino por competências e no ensino para compreensão. [tese]. São Paulo: Escola de Enfermagem, Universidade de São Paulo, 2014.

$\mathrm{Na}$ maioria dos itens o técnico de enfermagem tem desempenho melhor que os demais. O teste de Fisher tem significância em dez itens do rodízio de gestão. Provavelmente isso acontece porque o técnico, segundo a legislação vigente tem uma carga horária de 1200 horas $^{29}$

A Indicação CEE nº 08/2000 ${ }^{30}$ - Como é de sua competência, o Conselho Estadual de Educação de São Paulo fixou que, para ocupações regulamentadas por Lei, como é o caso da Enfermagem, a duração mínima a ser exigida para estágios supervisionados não poderá ser inferior a $50 \%$ da carga horária mínima da respectiva habilitação profissional, ou seja, 600 horas. Isto quer dizer que o curso de Técnico em Enfermagem deve ser estruturado com a carga horária mínima de 1800 horas. Incluindo as disciplinas que atendem 
ao ciclo vital na teoria e na prática, saúde da criança, mulher, adulto, idoso, além de terapia intensiva e estágio de gestão em enfermagem.

Quadro 11: Comparação das subcategorias e o turno de trabalho dos estudantes. São Paulo, 2012

\begin{tabular}{|l|c|c|c|}
\hline & \multicolumn{3}{|c|}{ Valor -P } \\
\hline & $\begin{array}{c}\text { Não } \\
\text { Trabalha } \\
\text { X } \\
\text { Tarde }\end{array}$ & $\begin{array}{c}\text { Não } \\
\text { Trabalha } \\
\text { Noite }\end{array}$ & $\begin{array}{c}\text { Tarde } \\
\text { Noite }\end{array}$ \\
\hline Medicamentos Rodízio 1 & 1,000 & 0,025 & 0,006 \\
\hline Unidade Rodízio 1 & 0,993 & 0,090 & 0,024 \\
\hline Técnica Rodízio 1 & 0,590 & 0,004 & 0,013 \\
\hline SAE Rodízio 1 & 0,873 & 0,011 & 0,009 \\
\hline Documenta Rodízio1 & 0,976 & 0,020 & 0,002 \\
\hline Cuidados Especializados Rodízio & 0,754 & 0,009 & 0,000 \\
\hline Ações de Enfermagem Rodízio 1 & 0,703 & 0,186 & 0,010 \\
\hline Anatomia e Fisiologia Rodízio 2 & 0,765 & 0,059 & 0,002 \\
\hline Fisiopatologia Rodízio 2 & 0,571 & 0,028 & 0,000 \\
\hline Medicamentos Rodízio 2 & 0,948 & 0,000 & 0,000 \\
\hline Exames Rodízio 2 & 0,945 & 0,001 & 0,000 \\
\hline Visitas Rodízio 2 & 0,942 & 0,006 & 0,002 \\
\hline Reconhece a Clientela Rodízio 2 & 0,583 & 0,033 & 0,123 \\
\hline Técnica Rodízio 2 & 0,981 & 0,030 & 0,013 \\
\hline SAE Rodízio 2 & 0,481 & 0,044 & 0,000 \\
\hline Documenta Rodízio 2 & 0,957 & 0,009 & 0,003 \\
\hline Cuidados Especializados Rodízio2 & 0,938 & 0,027 & 0,018 \\
\hline Cumpre Prazos Rodízio 2 & 0,957 & 0,059 & 0,040 \\
\hline Ações de Enfermagem Rodízio 2 & 0,239 & 0,063 & 0,000 \\
\hline Orientações Rodízio 2 & 0,976 & 0,056 & 0,009 \\
\hline Efetividade das Ações Rodízio 2 & 0,965 & 0,007 & 0,003 \\
\hline Passagem de Plantão Rodízio 2 & 0,752 & 0,014 & 0,023 \\
\hline Trabalhos Rodízio 2 & 0,864 & 0,037 & 0,043 \\
\hline Assiduidade Rodízio 3 & 0,245 & 0,741 & 0,024 \\
\hline Passagem de Plantão Rodízio 3 & 0,956 & 0,158 & 0,034 \\
\hline Domínio do Conteúdo Rodízio 3 & 0,466 & 0,173 & 0,003 \\
\hline Documenta as Ações Rodízio 4 & 0,780 & 0,074 & 0,003 \\
\hline Anatomia e Fisiologia Rodízio 6 & 0,910 & 0,018 & 0,013 \\
\hline Medicamentos Rodízio 6 & 0,980 & 0,009 & 0,003 \\
\hline Indicadores Epidemiológicos Rodízio 6 & 0,820 & 0,022 & 0,029 \\
\hline Domínio Rodízio 6 & 0,042 & 1,000 & 0,019 \\
\hline Média Final & 0,979 & 0,106 & 0,024 \\
\hline
\end{tabular}

Fonte: Paranhos, WY. Análise do desempenho dos estudantes de enfermagem no ensino por competências e no ensino para compreensão. [tese]. São Paulo: Escola de Enfermagem, Universidade de São Paulo, 2014.

Em comparação com o desempenho e o turno de trabalho, na maioria dos itens, o estudante que trabalha no turno da tarde tem melhor desempenho que o que não trabalha e o que trabalha no turno noturno. Este dado colabora com o dado anterior que mostra que o técnico já tem formação na área da saúde e, portanto ele é um 
trabalhador que vai melhor que o estudante que não trabalha. $\mathrm{O}$ estudante que trabalha à noite apresenta alterações no seu organismo, pois a espécie humana é diurna, essa alterações são hormonais, psicológicas, comportamento e desempenho. ${ }^{31,32,33}$ 
5.CONCLUSÕES 


\section{CONCLUSÕES}

A análise dos dados nos permite concluir que os estudantes do estágio curricular que cursaram ambos os currículos são em sua maioria mulheres, entre 26 e 35 anos de idade, solteiras, técnicos de enfermagem que trabalham no turno da tarde.

Em relação à comparação da avaliação do desempenho dos estudantes do currículo $A$, não teve diferença estatística em relação à média geral dos estudantes do currículo $\mathrm{B}$.

A hipótese de que o desempenho dos estudantes do currículo modular baseado no marco conceitual do ensino para compreensão era melhor que dos estudantes do currículo por competência, não se confirmou.

Na comparação dos desempenhos dos estudantes do estágio curricular supervisionado do currículo baseado em competências e os do currículo modular baseado no ensino para compreensão, os primeiros mostraram melhor desempenho apenas na unidade de terapia intensiva.

Em relação à variável idade o estudante mais velho tem melhor desempenho que o mais novo.

Quando se compara o gênero, as mulheres têm desempenho melhor que os homens.

Quanto à formação na área da saúde, os estudantes que são técnicos de enfermagem têm desempenho melhor que os que são auxiliares de enfermagem e dos que não têm formação na área da saúde.

Com relação ao turno de trabalho, os alunos que trabalham à tarde têm melhores notas na avaliação de desempenho no estágio curricular supervisionado do que aqueles que trabalham à noite e os que não trabalham. Mais pesquisas devem ser realizadas para 
desmitificar o estudante do turno vespertino, pois, existem diversos estudos sobre o estudante e o trabalhador do turno noturno.

Concluímos também que, como a maioria das variáveis eram as mesmas, campo de estágio, professores e os instrumentos, o currículo passou a ser uma variável de pouca expressão para o resultado final dos alunos.

Reconhecemos que há limites da pesquisa documental, uma vez que utilizamos dados previamente coletados e verificamos que diversos itens no instrumento de avaliação de desempenho dos estudantes no estágio curricular supervisionado precisam de revisão. Portanto, sugerimos que, baseado nessa pesquisa, criemos um grupo de estudos dos professores, da universidade campo do estudo, para que o instrumento seja modificado à luz do referencial teórico sobre avaliação.

Outro limite desse estudo foi que elegemos a avaliação do desempenho do estudante no último ano para analisar e somente uma turma de cada currículo, para analisarmos a influencia dos currículos no aprendizado será preciso novos estudos que analisem o desempenho do estudante também ao longo das disciplinas teórico-práticas.

Sugerimos que novas pesquisas sejam feitas para uma melhor interpretação e análise da avaliação de desempenho dos estudantes durante o estágio supervisionado, pois, acreditamos ser esse o ponto chave da formação do estudante de enfermagem, onde ele aprende fazendo.

É preciso uma autoavaliação dos professores, pautado no projeto pedagógico do curso, especialmente em relação às competências e habilidades propostas para o perfil do egresso. 
Concluímos também que esses dados contribuem para um adensamento da linha de pesquisa: Formação e gerenciamento de recursos humanos em enfermagem e em saúde

Este estudo evidencia alguns pontos: a avaliação de desempenho do estudante no estágio curricular supervisionado deve ser melhor estruturada, deve existir uma capacitação dos professores para a execução dessa tarefa. 
6. REFERÊNCLAS BIBLIOGR ÁFICAS 


\section{REFERÊNCIAS BIBLIOGRÁFICAS:}

1. Campos DA (Coord.). Docência no cenário do Ensino para a Compreensão. São Paulo: UNICID, 2009.

2. Wiske, MS. et al. Ensino para a compreensão: a pesquisa na prática. Porto Alegre: Artmed, 2007.

3. De Domenico, EBL, Ide CA C. Referências para o ensino de competências na enfermagem. Rev Bras Enferm 2005 jul-ago; 58(4):453-7.

4. Ricardo, EC Discussão acerca do ensino por competências: problemas e alternativas. Cadernos de Pesquisa, v.40, n.140, p. 605-628, maio/ago. 2010.

5. Brasil Conselho Nacional de Educação. Câmara de Educação Superior. Resolução CNE/CES N. 3, de 07 de novembro de 2001. Institui as Diretrizes Curriculares Nacionais do curso de graduação em enfermagem. Diário Oficial da República Federativa da União. Brasília, 09 nov. 2001. Seção 1, p. 37.

6. Zabalza, MA. O ensino universitário - seu cenário e seus protagonistas. Porto Alegre: Artmed, 2004

7. Braccialli, LAD; Oliveira, MA C de. Concepções de avaliação de desempenho em um currículo orientado por competência. Rev. esc. enferm. USP, São Paulo, v. 45, n. 5, Oct. 2011. Available from <http://www.scielo.br/scielo.php?script=sci_arttext\&pid=S0080$62342011000500027 \&$ Ing $=$ en\&nrm $=$ iso $>$. access on 16 June 2014. http://dx.doi.org/10.1590/S0080-62342011000500027.

8. Weiszflog, W Dicionário Michaellis. São Paulo: Editora Melhoramentos, 2012. 
9. Leite, MMJ; Peres, HHC; Gonçalves, VLM Educação continuada: recrutamento e seleção, treinamento e desenvolvimento, e avaliação de desempenho profissional. In: KURCGANT, P (coord) Gerenciamento em enfermagem. Rio de Janeiro: Guanabara Koogan, 2005

10. Pierantoni, $\mathrm{CR}$ et al. Performance evaluation: discussing technology for planning and managing health worforce. Rev. esc. enferm. USP, São Paulo, v. 45, n. spe, Dec. 2011. Available from $<$ http://www.scielo.br/scielo.php?script=sci_arttext\&pid=S0080$62342011000700014 \& \operatorname{lng}=$ en\&nrm=iso $>$. access on 10 June 2014. http://dx.doi.org/10.1590/S0080-62342011000700014.

11. Brasil, Lei Federal $n 7,498$ de 25 de junho de 1986. Dispõe sobre a regulamentação do exercício da enfermagem. Diário Oficial da União. Brasília, 26 de junho de 1986.

12. Silva, GM da. Instrumentos e práticas avaliativas dos Estágios de Enfermagem em Instituições hospitalares: perspectivas de Coordenadores e Docentes. São Paulo, 2011 Tese (doutorado)Programa de pós-graduação em Educação. Área de concentração: didática, teorias do ensino e práticas escolares) Faculdade de Educação da Universidade de São Paulo.

13. PRADO, Rosane Aparecida do; PRADO, Marta Lenise do; REIBNITZ, Kenya Schimdt. Desvelando o significado da avaliação no ensino por competência para enfermeiros educadores. Revista Eletrônica de Enfermagem, [S.I.], v. 14, n. 1, p. 112-21, mar. 2012. ISSN 1518-1944. Disponível em: $<$ http://h200137217135.ufg.br/index.php/fen/article/view/12705/1556 3ㄱ. Acesso em: 25 Jun. 2014. doi:10.5216/ree.v14i1.12705

14. Friedländer, M R. Como Supervisionar um estágio em enfermagem. São Paulo: Editora Green Forest do Brasil, 2005.

15. Flening R S. Currículo moderno: um planejamento dinâmico das mais avançadas técnicas de ensino. Tradução de Marina Couto e $\mathrm{M}$. Eleonora Brant. 2ª ed. Rio de Janeiro: Brasília Lidador INL, 1974. 
16. Sacristán JG, Goméz, AIP Compreender e transformar o ensino. 4ed. Porto Alegre: Artmed, 1998.

17. Perrenoud P. Avaliação: da excelência à regulação das aprendizagens entre duas lógicas. Porto Alegre: Artmed, 1999. Reimpressão 2007. 184p.

18. Luckesi CC. Avaliação da Aprendizagem escolar: estudos e proposições. 22 ed. São Paulo: Cortez, 2011

19. Projeto pedagógico do Curso de enfermagem, 2008

20. Esteban, MT (org) Escola, currículo e avaliação. 3 ed. São Paulo: Cortez, 2008

21. Shute, VJ.; KIM, YJ Formative and Stealth Assessment. Handbook of research on Education and Technology. 2014, p. 311321. http://link. springer.com/chapter. Acesso em 20/05/2014 as 23h

22. Projeto pedagógico do curso de enfermagem, 2009

23.. Gil AC. Métodos e técnicas de pesquisa social. 5ed. São Paulo: Atlas, 1999.

24. Lattin J; Carroll, JD; Green, PE. Análise de dados multivariados. Cengage Learning: São Paulo, 2011

25. Brito AMR de; Brito MJM; Silva PAB. Perfil Sociodemográfico de Discentes de Enfermagem de Instituições de Ensino Superior de Belo Horizonte. Esc Anna Nery Rev Enferm 2009 abr-jun; 13 (2): 328-33

26. Spíndola T, Martins ER da C, Francisco, MTR Enfermagem como opção: perfil de graduandos de duas instituições de ensino. Rev Bras Enferm, Brasília 2008 mar-abr; 61(2): 164-9.

27. Santos C E; Leite MMJ O perfil do aluno ingressante em uma universidade particular da cidade de São Paulo. Rev Bras Enferm 2006 mar-abr; 59(2): 154-6.

28. Costa, M L A de S; Merighi, MAB; Jesus, MCP e. Ser enfermeiro tendo sido estudante-trabalhador de enfermagem: um enfoque da fenomenologia social. Acta paul. enferm., São Paulo, v. 21, n. 1, mar. $2008 \quad$ Disponível em <http://www.scielo.br/scielo.php?script=sci_arttext\&pid=S0103-

21002008000100003\&lng=pt\&nrm=iso>. acessos em 10 jun. 2014. http://dx.doi.org/10.1590/S0103-21002008000100003.

29. Sherman T; Kurshan B Teaching for Understanding. Learning \& Leading whith Tecnology. December/January, 2004-5. 32 (4):6-11 
30. Brasil Conselho Nacional de Educação, Resolução CNE/CEB no 04/99 - institui as Diretrizes Curriculares Nacionais para a Educação Profissional de Nível Técnico (1.200h)

31. São Paulo, Conselho Estadual de Educação Indicação no 8/2000 - Institui a duração mínima dos estágios para as profissões regulamentadas por lei.

32. Lisboa MTL, Oliveira M M, Reis L D O Trabalho Noturno e a prática da enfermagem: uma percepção dos estudantes de enfermagem. Esc Anna Nery R enfermagem, 2006 dez; 10 (3): 393-8

33. Maynardes D de CD, Sarquis LMM, Kirchhof A L C. Trabalho noturno e morbidades de trabalhadores de enfermagem. Cogitare enferm. [periódico na Internet]. 2009 Dic [citado 2014 Jun 25] ; 14 (4): 703-708. Disponible en: http://www.revenf.bvs.br/scielo.php?script=sci arttext\&pid=S1414$85362009000400014 \& \operatorname{lng}=\mathrm{es}$.

34. Lima, MCMR. A influência do trabalho no rendimento escolar dos estudantes trabalhadores de graduação em enfermagem: uma revisão integrativa. Dissertação (Mestrado). Universidade de Guarulhos, 2010 


\section{APÊNDICES}




\section{APÊNDICE 1 - MÉDIAS DOS ALUNOS DO CURRÍCULO A, POR} RODÍZIO.

\begin{tabular}{|l|r|r|r|r|r|r|r|}
\hline & Rod. 1 & Rod. 2 & Rod. 3 & Rod. 4 & Rod. 5 & Rod. 6 & Média \\
\hline Aluno 1 & 7,50 & 7,28 & 7,00 & 8,08 & 7,50 & 7,15 & 7,42 \\
\hline Aluno 2 & 7,50 & 7,00 & 7,80 & 6,5 & 8,00 & 8,00 & 7,47 \\
\hline Aluno 3 & 7,70 & 7,66 & 7,59 & 8 & 6,70 & 7,99 & 7,61 \\
\hline Aluno 4 & 5,60 & 6,23 & 4,70 & 6 & 5,00 & 6,92 & 5,74 \\
\hline Aluno 5 & 6,00 & 7,33 & 6,90 & 6,88 & 4,50 & 7,74 & 6,56 \\
\hline Aluno 6 & 6,30 & 6,89 & 6,00 & 7 & 7,00 & 7,13 & 6,72 \\
\hline Aluno 7 & 7,50 & 6,79 & 8,60 & 8,15 & 6,00 & 8,09 & 7,52 \\
\hline Aluno 8 & 7,30 & 5,94 & 7,52 & 7,2 & 5,00 & 6,23 & 6,53 \\
\hline Aluno 9 & 6,73 & 5,86 & 6,48 & 7,5 & 5,80 & 6,24 & 6,44 \\
\hline Aluno 10 & 6,40 & 6,10 & 7,50 & 6,72 & 4,50 & 6,04 & 6,21 \\
\hline Aluno 11 & 7,00 & 6,23 & 5,46 & 6,5 & 5,00 & 7,81 & 6,33 \\
\hline Aluno 12 & 6,69 & 7,00 & 5,60 & 6,36 & 7,00 & 7,28 & 6,66 \\
\hline Aluno 13 & 8,10 & 6,80 & 8,60 & 8,15 & 8,00 & 8,15 & 7,97 \\
\hline Aluno 14 & 6,69 & 6,50 & 6,88 & 6,5 & 7,00 & 7,19 & 6,79 \\
\hline Aluno 15 & 7,30 & 7,89 & 7,60 & 6,9 & 7,50 & 6,11 & 7,22 \\
\hline Aluno 16 & 8,10 & 7,18 & 6,80 & 7,44 & 7,00 & 7,33 & 7,31 \\
\hline Aluno 17 & 8,40 & 7,69 & 7,39 & 7 & 7,60 & 7,22 & 7,55 \\
\hline Aluno 18 & 6,70 & 6,62 & 6,08 & 6,75 & 6,00 & 8,28 & 6,74 \\
\hline Aluno 19 & 6,94 & 7,81 & 6,20 & 7 & 6,70 & 7,60 & 7,04 \\
\hline Aluno 20 & 7,65 & 7,42 & 7,35 & 7,7 & 6,50 & 6,32 & 7,16 \\
\hline Aluno 21 & 8,50 & 8,26 & 8,90 & 8 & 8,50 & 8,87 & 8,51 \\
\hline Aluno 22 & 7,60 & 7,36 & 7,58 & 8 & 7,40 & 6,10 & 7,34 \\
\hline Aluno 23 & 5,00 & 7,51 & 7,50 & 7,5 & 8,00 & 7,44 & 7,16 \\
\hline Aluno 24 & 8,00 & 7,40 & 7,20 & 7,17 & 6,50 & 8,08 & 7,39 \\
\hline Aluno 25 & 8,00 & 7,00 & 7,80 & 7 & 7,00 & 6,61 & 7,24 \\
\hline Aluno 26 & 7,77 & 7,33 & 6,45 & 8,5 & 7,90 & 9,02 & 7,83 \\
\hline Aluno 27 & 6,40 & 7,00 & 5,85 & 6,5 & 5,20 & 6,68 & 6,27 \\
\hline Aluno 28 & 8,00 & 6,78 & 7,73 & 7 & 7,25 & 7,37 & 7,36 \\
\hline Aluno 29 & 8,00 & 7,81 & 8,23 & 8,00 & 8,25 & 8,48 & 8,13 \\
\hline Aluno 30 & 4,90 & 5,80 & 3,07 & 5,70 & 5,20 & 6,62 & 5,22 \\
\hline Aluno 31 & 6,50 & 7,67 & 7,61 & 8,50 & 8,40 & 6,68 & 7,56 \\
\hline Aluno 32 & 7,80 & 6,83 & 7,80 & 6,23 & 5,00 & 6,76 & 6,74 \\
\hline Aluno 33 & 7,80 & 8,35 & 7,49 & 8,00 & 7,90 & 9,06 & 8,10 \\
\hline
\end{tabular}


APÊNDICE 2 - MÉDIAS DOS ALUNOS DO CURRÍCULO B, POR RODÍZIO:

\begin{tabular}{|l|r|r|r|r|r|r|r|}
\hline & Rod. 1 & Rod. 2 & Rod. 3 & Rod. 4 & Rod. 5 & Rod. 6 & Média \\
\hline Aluno 1 & 7,60 & 8,39 & 6,75 & 7,76 & 7 & 7,52 & 7,50 \\
\hline Aluno 2 & 5,84 & 7,2 & 4,91 & 6,2 & 7 & 6,37 & 6,25 \\
\hline Aluno 3 & 6,90 & 6,4 & 4,8 & 7,1 & 7,75 & 7,36 & 6,72 \\
\hline Aluno 4 & 7,50 & 7,55 & 8,52 & 8,16 & 8 & 6,87 & 7,77 \\
\hline Aluno 5 & 6,13 & 7,2 & 6,94 & 7,05 & 6,5 & 8,28 & 7,02 \\
\hline Aluno 6 & 5,87 & 6,36 & 4,96 & 6,93 & 7 & 6,17 & 6,22 \\
\hline Aluno 7 & 8,10 & 8,82 & 7,5 & 7,7 & 7 & 8,59 & 7,95 \\
\hline Aluno 8 & 8,50 & 8,24 & 8,09 & 7,5 & 8,5 & 6,89 & 7,95 \\
\hline Aluno 9 & 7,60 & 7,33 & 5,68 & 7,98 & 7 & 7,52 & 7,19 \\
\hline Aluno 10 & 8,10 & 7,34 & 6,49 & 7,45 & 8 & 7,67 & 7,51 \\
\hline Aluno 11 & 6,96 & 7,35 & 6,26 & 7,2 & 6,5 & 7,29 & 6,93 \\
\hline Aluno 12 & 7,00 & 7,1 & 6,6 & 7,65 & 7 & 7,49 & 7,14 \\
\hline Aluno 13 & 7,30 & 6,92 & 6,33 & 7,3 & 7,25 & 7,46 & 7,09 \\
\hline Aluno 14 & 7,75 & 7,58 & 7,27 & 7,6 & 6,7 & 8,94 & 7,64 \\
\hline Aluno 15 & 7,20 & 6,65 & 4,69 & 7,1 & 6,75 & 6,9 & 6,55 \\
\hline Aluno 16 & 8,90 & 8,88 & 8,56 & 7,58 & 6,75 & 6,51 & 7,86 \\
\hline Aluno 17 & 6,00 & 6,95 & 5,16 & 5,75 & 5,75 & 6,39 & 6,00 \\
\hline Aluno 18 & 7,22 & 7,22 & 6 & 7,96 & 7 & 6,63 & 7,01 \\
\hline
\end{tabular}


APÊNDICE 3 : Comparação das notas dos alunos dos currículos a e b, por rodízio, por subcategoria do instrumento de avaliação.

\begin{tabular}{|c|c|c|c|c|c|}
\hline & \multicolumn{2}{|c|}{$\mathrm{A}(\mathrm{N}=33)$} & \multicolumn{2}{|c|}{$\mathrm{B}(\mathrm{N}=18)$} & \multirow[b]{2}{*}{ Valor-p } \\
\hline & Média & DP & Média & DP & \\
\hline $\begin{array}{l}\text { Bases Comportamentais } \\
\text { Nota Final - Rodízio } 1\end{array}$ & 1,763 & 0,105 & 3,181 & 0,271 & 0,000 \\
\hline $\begin{array}{l}\text { Conhecimentos } \\
\text { Nota Final - Rodízio } 1\end{array}$ & 1,882 & 0,426 & 1,925 & 0,300 & 0,678 \\
\hline Pratica Assistencial Nota Final - Rodízio 1 & 2,186 & 0,281 & 2,214 & 0,275 & 0,739 \\
\hline Trabalhos Nota Final - Rodízio 1 & 1,675 & 0,195 & 1,631 & 0,219 & 0,467 \\
\hline $\begin{array}{l}\text { Bases Comportamentais } \\
\text { Nota Final - Rodízio } 2\end{array}$ & 1,797 & 0,090 & 1,781 & 0,095 & 0,563 \\
\hline Conhecimentos Nota Final - Rodízio 2 & 1,767 & 0,418 & 1,876 & 0,376 & 0,361 \\
\hline Pratica Assistencial Nota Final - Rodízio 2 & 1,869 & 0,288 & 2,002 & 0,253 & 0,106 \\
\hline Trabalhos Nota Final - Rodízio 2 & 1,832 & 0,171 & 1,746 & 0,184 & 0,101 \\
\hline Bases Comportamentais Nota Final - Rodízio 3 & 1,741 & 0,217 & 1,597 & 0,306 & 0,089 \\
\hline Conhecimentos Nota Final - Rodízio 3 & 1,762 & 0,499 & 1,603 & 0,407 & 0,251 \\
\hline Pratica Assistencial Nota Final - Rodízio 3 & 2,306 & 0,238 & 2,075 & 0,386 & 0,030 \\
\hline Trabalhos Nota Final - Rodízio 3 & 1,397 & 0,339 & 1,438 & 0,376 & 0,689 \\
\hline Bases Comportamentais Nota Final - Rodízio 4 & 1,674 & 0,141 & 1,656 & 0,099 & 0,621 \\
\hline Conhecimentos Científicos Nota Final - Rodízio 4 & 1,883 & 0,301 & 1,904 & 0,194 & 0,762 \\
\hline Pratica Assistencial Nota Final - Rodízio 4 & 1,994 & 0,431 & 1,894 & 0,300 & 0,389 \\
\hline $\begin{array}{l}\text { Ações Educativas } \\
\text { Nota Final - Rodízio } 4\end{array}$ & 1,841 & 0,298 & 777 & ,289 & 0,459 \\
\hline Atitudinal Nota Final - Rodízio 5 & 0,849 & 0,114 & 0,865 & 0,066 & 0,520 \\
\hline Gestão de Pessoas Nota Final - Rodízio 5 & 0,685 & 0,168 & 0,729 & 0,109 & 0,322 \\
\hline Gestão de Cuidados Nota Final - Rodízio 5 & 2,418 & 0,441 & 2,339 & 0,248 & 0,419 \\
\hline Gestão Administrativa 1 Nota Final - Rodízio 5 & 2,523 & 0,471 & 2,460 & 0,179 & 0,494 \\
\hline Gestão Administrativa 2 Nota Final - Rodízio 5 & 0,826 & 0,092 & 0,837 & 0,119 & 0,728 \\
\hline $\begin{array}{l}\text { Desenvolvimento Pessoal } \\
\text { Nota Final - Rodízio } 5\end{array}$ & 0,733 & 0,173 & 0,867 & 0,301 & 0,048 \\
\hline $\begin{array}{l}\text { Bases Comportamentais } \\
\text { Nota Final - Rodízio } 6\end{array}$ & 1,721 & 0,219 & 1,798 & 0,100 & 0,094 \\
\hline $\begin{array}{l}\text { Conhecimentos Científicos } \\
\text { Nota Final - Rodízio } 6\end{array}$ & 2,010 & 0,328 & 1,928 & 0,287 & 0,382 \\
\hline Pratica Assistencial Nota Final - Rodízio 6 & 2,066 & 0,381 & 2,030 & 0,321 & 0,733 \\
\hline $\begin{array}{l}\text { Ações Educativas } \\
\text { Nota Final - Rodízio } 6\end{array}$ & 1,600 & 0,201 & 1,536 & 0,166 & 0,257 \\
\hline Média Final & 7,086 & 0,705 & 7,128 & 0,608 & 0,833 \\
\hline
\end{tabular}


APÊNDICE 4: Distribuição das notas de avaliação de acordo com o currículo cursado. São Paulo, 2012

\begin{tabular}{|c|c|c|c|c|c|}
\hline & \multicolumn{2}{|c|}{$A(N=33)$} & \multicolumn{2}{|c|}{$\mathrm{B}(\mathrm{N}=18)$} & \\
\hline & Média & DP & Média & DP & Valor-p \\
\hline Apresentação Pessoal & 0,182 & 0,000 & 1,650 & 0,157 & 0,000 \\
\hline Assiduidade & 0,140 & 0,034 & 0,127 & 0,035 & 0,210 \\
\hline Pontualidade & 0,135 & 0,038 & 0,127 & 0,036 & 0,449 \\
\hline Postura ética & 0,181 & 0,006 & 0,176 & 0,014 & 0,156 \\
\hline Interesse & 0,164 & 0,027 & 0,161 & 0,033 & 0,717 \\
\hline Comunicação & 0,131 & 0,025 & 0,134 & 0,013 & 0,656 \\
\hline Orientação & 0,167 & 0,023 & 0,173 & 0,017 & 0,297 \\
\hline Compromisso & 0,174 & 0,018 & 0,164 & 0,030 & 0,195 \\
\hline Uso de material pessoal & 0,169 & 0,023 & 0,169 & 0,022 & 0,990 \\
\hline Organização e liderança & 0,155 & 0,117 & 0,140 & 0,023 & 0,595 \\
\hline Relacionamento & 0,164 & 0,024 & 0,160 & 0,022 & 0,600 \\
\hline $\begin{array}{l}\text { Bases comportamentais } \\
\text { nota final }\end{array}$ & 1,763 & 0,105 & 3,181 & 0,271 & 0,000 \\
\hline Anatomia e fisiologia & 0,374 & 0,093 & 0,382 & 0,070 & 0,768 \\
\hline Fisiopatologia & 0,395 & 0,099 & 0,374 & 0,070 & 0,410 \\
\hline Medicamentos & 0,332 & 0,114 & 0,363 & 0,075 & 0,253 \\
\hline Exames & 0,362 & 0,112 & 0,385 & 0,065 & 0,367 \\
\hline Visitas & 0,418 & 0,090 & 0,422 & 0,073 & 0,871 \\
\hline $\begin{array}{l}\text { Conhecimentos } \\
\text { Nota final }\end{array}$ & 1,882 & 0,426 & 1,925 & 0,300 & 0,678 \\
\hline Reconhece a clientela & 0,238 & 0,042 & 0,218 & 0,050 & 0,138 \\
\hline Unidade & 0,188 & 0,025 & 0,191 & 0,035 & 0,801 \\
\hline Técnica & 0,201 & 0,039 & 0,216 & 0,045 & 0,228 \\
\hline SAE & 0,174 & 0,033 & 0,174 & 0,036 & 0,971 \\
\hline Documenta & 0,192 & 0,034 & 0,199 & 0,035 & 0,476 \\
\hline Cuidados especializados & 0,200 & 0,045 & 0,224 & 0,046 & 0,072 \\
\hline Cumpre prazos & 0,242 & 0,046 & 0,245 & 0,041 & 0,867 \\
\hline Ações de enfermagem & 0,183 & 0,031 & 0,184 & 0,022 & 0,944 \\
\hline Orientações & 0,188 & 0,026 & 0,187 & 0,023 & 0,877 \\
\hline Efetividade das ações & 0,181 & 0,031 & 0,172 & 0,025 & 0,286 \\
\hline Passagem de plantão & 0,199 & 0,042 & 0,205 & 0,035 & 0,578 \\
\hline Pratica assistencial nota final & 2,186 & 0,281 & 2,214 & 0,275 & 0,739 \\
\hline Estudo de caso & 0,264 & 0,046 & 0,258 & 0,039 & 0,648 \\
\hline Trabalhos & 0,251 & 0,057 & 0,227 & 0,055 & 0,152 \\
\hline Domínio do conteúdo & 0,232 & 0,053 & 0,229 & 0,054 & 0,856 \\
\hline Reunião & 0,198 & 0,050 & 0,201 & 0,040 & 0,819 \\
\hline Entrega & 0,286 & 0,000 & 0,280 & 0,026 & 0,331 \\
\hline Amplia a busca & 0,205 & 0,039 & 0,195 & 0,040 & 0,384 \\
\hline Amplia conhecimento & 0,240 & 0,047 & 0,243 & 0,049 & 0,875 \\
\hline Trabalhos nota final & 1,675 & 0,195 & 1,631 & 0,219 & 0,467 \\
\hline
\end{tabular}


APÊNDICE 5: Notas de avaliação do rodízio 2 de acordo com o currículo cursado.

\begin{tabular}{|c|c|c|c|c|c|}
\hline \multirow[b]{2}{*}{ Subcategorias } & \multicolumn{2}{|c|}{$A(N=33)$} & \multicolumn{2}{|c|}{$B(N=18)$} & \multirow[b]{2}{*}{ Valor $=P$} \\
\hline & Média & DP & Media & DP & \\
\hline Apresentação Pessoal & 0,182 & 0,000 & 0,176 & 0,018 & 0,163 \\
\hline Assiduidade & 0,140 & 0,034 & 0,127 & 0,035 & 0,210 \\
\hline Pontualidade & 0,135 & 0,038 & 0,127 & 0,036 & 0,449 \\
\hline Postura Ética & 0,181 & 0,006 & 0,176 & 0,014 & 0,156 \\
\hline Interesse & 0,164 & 0,027 & 0,161 & 0,033 & 0,717 \\
\hline Comunicação & 0,131 & 0,025 & 0,134 & 0,013 & 0,656 \\
\hline Orientação & 0,180 & 0,010 & 0,182 & 0,000 & 0,466 \\
\hline Compromisso & 0,182 & 0,000 & 0,180 & 0,008 & 0,331 \\
\hline Uso de Material Pessoal & 0,169 & 0,024 & 0,180 & 0,008 & 0,014 \\
\hline Organização e Liderança & 0,150 & 0,028 & 0,156 & 0,026 & 0,481 \\
\hline Relacionamento & 0,182 & 0,000 & 0,182 & 0,000 & 1,000 \\
\hline $\begin{array}{l}\text { Bases Comportamentais Nota } \\
\text { Final }\end{array}$ & 1,797 & 0,090 & 1,781 & 0,095 & 0,563 \\
\hline Anatomia e Fisiologia & 0,372 & 0,092 & 0,387 & 0,079 & 0,543 \\
\hline Fisiopatologia & 0,362 & 0,090 & 0,371 & 0,076 & 0,729 \\
\hline Medicamentos & 0,338 & 0,079 & 0,371 & 0,076 & 0,156 \\
\hline Exames & 0,344 & 0,097 & 0,371 & 0,078 & 0,319 \\
\hline Visitas & 0,352 & 0,092 & 0,376 & 0,080 & 0,340 \\
\hline Conhecimentos Nota Final & 1,767 & 0,418 & 1,876 & 0,376 & 0,361 \\
\hline Reconhece a Clientela & 0,173 & 0,030 & 0,173 & 0,020 & 0,934 \\
\hline Unidade & 0,182 & 0,035 & 0,174 & 0,021 & 0,406 \\
\hline Técnica & 0,176 & 0,042 & 0,199 & 0,033 & 0,051 \\
\hline SAE & 0,158 & 0,030 & 0,180 & 0,032 & 0,017 \\
\hline Documenta & 0,162 & 0,038 & 0,177 & 0,029 & 0,154 \\
\hline Cuidados Especializados & 0,173 & 0,042 & 0,202 & 0,036 & 0,021 \\
\hline Cumpre Prazos & 0,175 & 0,031 & 0,178 & 0,027 & 0,725 \\
\hline Ações e Enfermagem & 0,169 & 0,032 & 0,177 & 0,029 & 0,370 \\
\hline Orientações & 0,162 & 0,029 & 0,177 & 0,031 & 0,088 \\
\hline Efetividade $\mathrm{d}$ & 0,165 & 0,028 & 0,181 & 0,033 & 0,070 \\
\hline Passagem de Plantão & 0,173 & 0,036 & 0,184 & 0,025 & 0,271 \\
\hline Pratica Assistencial Nota Final & 1,869 & 0,288 & 2,002 & 0,253 & 0,106 \\
\hline Estudo de Caso & 0,280 & 0,024 & 0,281 & 0,014 & 0,848 \\
\hline Trabalhos & 0,246 & 0,054 & 0,260 & 0,043 & 0,313 \\
\hline Domínio do Conteúdo & 0,257 & 0,048 & 0,255 & 0,044 & 0,889 \\
\hline Reunião & 0,259 & 0,048 & 0,233 & 0,048 & 0,073 \\
\hline Entrega & 0,276 & 0,032 & 0,258 & 0,047 & 0,154 \\
\hline Amplia a Busca & 0,258 & 0,047 & 0,234 & 0,053 & 0,095 \\
\hline Amplia Conhecin & 0,256 & 0,046 & 0,225 & 0,053 & 0,036 \\
\hline Trabalhos Nota Final & 1,832 & 0,171 & 1,746 & 0,184 & 0,101 \\
\hline
\end{tabular}


APÊNDICE 6 - Distribuição das notas de avaliação do rodízio três de acordo com o currículo cursado.

\begin{tabular}{|c|c|c|c|c|c|}
\hline & \multicolumn{2}{|c|}{$A(N=33)$} & \multicolumn{2}{|c|}{$\mathrm{B}(\mathrm{N}=18)$} & \multirow[b]{2}{*}{ VALOR $=P$} \\
\hline & MÉDIA & DP & MÉDIA & DP & \\
\hline Apresentação Pessoal & 0,168 & 0,024 & 0,160 & 0,045 & 0,446 \\
\hline Assiduidade & 0,132 & 0,054 & 0,141 & 0,040 & 0,527 \\
\hline Pontualidade & 0,132 & 0,041 & 0,132 & 0,045 & 0,994 \\
\hline Postura Ética & 0,172 & 0,022 & 0,168 & 0,035 & 0,627 \\
\hline Interesse & 0,167 & 0,034 & 0,139 & 0,058 & 0,072 \\
\hline Comunicação & 0,140 & 0,036 & 0,120 & 0,034 & 0,059 \\
\hline Orientação & 0,167 & 0,032 & 0,137 & 0,039 & 0,005 \\
\hline Compromisso & 0,169 & 0,033 & 0,151 & 0,054 & 0,218 \\
\hline Uso de Material Pessoal & 0,171 & 0,024 & 0,169 & 0,027 & 0,802 \\
\hline Organização e Liderança & 0,144 & 0,043 & 0,114 & 0,045 & 0,023 \\
\hline Relacionamento & 0,178 & 0,014 & 0,164 & 0,034 & 0,130 \\
\hline Bases Comportamentais Nota Final & 1,741 & 0,217 & 1,597 & 0,306 & 0,089 \\
\hline Anatomia e Fisiologia & 0,373 & 0,088 & 0,333 & 0,123 & 0,236 \\
\hline Fisiopatologia & 0,288 & 0,158 & 0,283 & 0,113 & 0,906 \\
\hline Medicamentos & 0,323 & 0,131 & 0,367 & 0,104 & 0,225 \\
\hline Exames & 0,355 & 0,146 & 0,292 & 0,101 & 0,111 \\
\hline Visitas & 0,424 & 0,128 & 0,328 & 0,101 & 0,008 \\
\hline Conhecimentos Nota Final & 1,762 & 0,499 & 1,603 & 0,407 & 0,251 \\
\hline Reconhece a Clientela & 0,245 & 0,111 & 0,250 & 0,142 & 0,889 \\
\hline Unidade & 0,242 & 0,051 & 0,224 & 0,047 & 0,219 \\
\hline Técnica & 0,201 & 0,053 & 0,200 & 0,068 & 0,934 \\
\hline SAE & 0,170 & 0,036 & 0,152 & 0,064 & 0,279 \\
\hline Documenta & 0,190 & 0,051 & 0,175 & 0,059 & 0,334 \\
\hline Cuidados Especializados & 0,233 & 0,113 & 0,215 & 0,153 & 0,629 \\
\hline Cumpre Prazos & 0,223 & 0,057 & 0,184 & 0,065 & 0,034 \\
\hline Ações de Enfermagem & 0,204 & 0,061 & 0,174 & 0,066 & 0,115 \\
\hline Orientações & 0,179 & 0,035 & 0,162 & 0,055 & 0,234 \\
\hline Efetividade das Ações & 0,191 & 0,055 & 0,156 & 0,053 & 0,032 \\
\hline Passagem de Plantão & 0,229 & 0,057 & 0,184 & 0,071 & 0,019 \\
\hline Prática Assistencial Nota Final & 2,306 & 0,238 & 2,075 & 0,386 & 0,030 \\
\hline Estudo de Caso & 0,195 & 0,071 & 0,224 & 0,074 & 0,180 \\
\hline Trabalhos & 0,192 & 0,057 & 0,181 & 0,075 & 0,559 \\
\hline Domínio do Conteúdo & 0,157 & 0,064 & 0,177 & 0,072 & 0,328 \\
\hline Reunião & 0,188 & 0,079 & 0,188 & 0,069 & 0,992 \\
\hline Entrega & 0,252 & 0,059 & 0,266 & 0,053 & 0,403 \\
\hline Amplia a Busca & 0,198 & 0,078 & 0,204 & 0,069 & 0,800 \\
\hline Amplia Conhecimento & 0,215 & 0,061 & 0,200 & 0,068 & 0,401 \\
\hline Trabalhos Nota Final & 1,397 & 0,339 & 1,438 & 0,376 & 0,689 \\
\hline
\end{tabular}


APÊNDICE 7: Distribuição das notas de avaliação do rodízio quatro de acordo com o currículo cursado.

\begin{tabular}{|c|c|c|c|c|c|}
\hline & \multicolumn{2}{|c|}{$\mathrm{A}(\mathrm{N}=33)$} & \multicolumn{2}{|c|}{$\mathrm{B}(\mathrm{N}=18)$} & \\
\hline & Média & $\mathrm{Dp}$ & Média & $\mathrm{Dp}$ & Valor-p \\
\hline Apresentação Pessoal & 0,200 & 0,000 & 0,200 & 0,000 & 0,018 \\
\hline Assiduidade & 0,167 & 0,053 & 0,163 & 0,034 & 0,749 \\
\hline Pontualidade & 0,144 & 0,053 & 0,147 & 0,050 & 0,829 \\
\hline Orientação & 0,191 & 0,029 & 0,197 & 0,012 & 0,385 \\
\hline Material de Uso Pessoal & 0,188 & 0,033 & 0,194 & 0,024 & 0,461 \\
\hline Postura & 0,176 & 0,044 & 0,139 & 0,050 & 0,009 \\
\hline Construção de Relacionamentos & 0,182 & 0,039 & 0,175 & 0,043 & 0,568 \\
\hline Interesse & 0,142 & 0,050 & 0,159 & 0,042 & 0,202 \\
\hline Organização e Liderança & 0,106 & 0,024 & 0,108 & 0,026 & 0,755 \\
\hline Responsabilidade e Compromisso & 0,179 & 0,042 & 0,172 & 0,039 & 0,585 \\
\hline Bases Comportamentais Nota Final & 1,674 & 0,141 & 1,656 & 0,099 & 0,621 \\
\hline Anatomia e Fisiologia & 0,191 & 0,068 & 0,181 & 0,060 & 0,591 \\
\hline Medicamentos & 0,167 & 0,076 & 0,145 & 0,029 & 0,142 \\
\hline Relaciona Exames & 0,152 & 0,030 & 0,149 & 0,026 & 0,751 \\
\hline Dinâmica da Unidade & 0,218 & 0,076 & 0,232 & 0,073 & 0,538 \\
\hline Programas de Saúde & 0,150 & 0,000 & 0,150 & 0,000 & 1,000 \\
\hline Planeja e Organiza & 0,245 & 0,073 & 0,248 & 0,058 & 0,879 \\
\hline Prioridades & 0,255 & 0,070 & 0,263 & 0,053 & 0,640 \\
\hline Indicadores Epidemiológicos & 0,150 & 0,000 & 0,150 & 0,000 & 1,000 \\
\hline Analisa dados & 0,152 & 0,030 & 0,158 & 0,023 & 0,488 \\
\hline Preenche Relatórios & 0,202 & 0,076 & 0,228 & 0,070 & 0,235 \\
\hline Conhecimentos Científicos Nota Final & 1,883 & 0,301 & 1,904 & 0,194 & 0,762 \\
\hline Técnicas Básicas & 0,285 & 0,113 & 0,248 & 0,077 & 0,179 \\
\hline Estado Clinico & 0,315 & 0,114 & 0,340 & 0,086 & 0,379 \\
\hline Documenta as Ações & 0,245 & 0,091 & 0,281 & 0,089 & 0,181 \\
\hline Consulta & 0,212 & 0,045 & 0,213 & 0,029 & 0,914 \\
\hline Analisa as Ações & 0,262 & 0,097 & 0,210 & 0,001 & 0,004 \\
\hline Organiza o Trabalho & 0,335 & 0,113 & 0,302 & 0,093 & 0,274 \\
\hline Passagem de Plantão & 0,342 & 0,112 & 0,301 & 0,104 & 0,206 \\
\hline Pratica Assistencial Nota Final & 1,994 & 0,431 & 1,894 & 0,300 & 0,389 \\
\hline Educação em Saúde & 0,320 & 0,070 & 0,287 & 0,066 & 0,115 \\
\hline Busca Extra Estágio & 0,264 & 0,094 & 0,300 & 0,071 & 0,133 \\
\hline Raciocínio Crítico & 0,264 & 0,090 & 0,300 & 0,071 & 0,119 \\
\hline Apresentação do Trabalho & 0,331 & 0,057 & 0,299 & 0,061 & 0,066 \\
\hline Domínio & 0,320 & 0,070 & 0,310 & 0,053 & 0,592 \\
\hline s Tarefas & 0,343 & 0,045 & 0,281 & 0,070 & 0,002 \\
\hline Ações Educativas Nota Final & 1,841 & 0,298 & 1,777 & 0,289 & 0,459 \\
\hline
\end{tabular}


APÊNDICE 8: Distribuição das notas de avaliação do rodízio 5 de acordo com o currículo cursado.

\begin{tabular}{|c|c|c|c|c|c|}
\hline & \multicolumn{2}{|c|}{$A(N=33)$} & \multicolumn{2}{|c|}{$\mathrm{B}(\mathrm{N}=18)$} & \multirow[b]{2}{*}{ VALOR $=p$} \\
\hline & MÉDIA & DP & MÉDIA & DP & \\
\hline Apresentação Pessoal & 0,098 & 0,014 & 0,099 & 0,004 & 0,674 \\
\hline Assiduidade & 0,079 & 0,025 & 0,079 & 0,015 & 0,966 \\
\hline Pontualidade & 0,072 & 0,032 & 0,077 & 0,024 & 0,569 \\
\hline Postura Ética & 0,099 & 0,006 & 0,100 & 0,000 & 0,466 \\
\hline Interesse & 0,085 & 0,023 & 0,083 & 0,016 & 0,795 \\
\hline Comunicação & 0,083 & 0,021 & 0,087 & 0,016 & 0,378 \\
\hline Orientação & 0,092 & 0,021 & 0,093 & 0,012 & 0,837 \\
\hline Compromissos & 0,088 & 0,020 & 0,082 & 0,025 & 0,317 \\
\hline Organização & 0,066 & 0,024 & 0,073 & 0,012 & 0,256 \\
\hline Relacionamento & 0,088 & 0,022 & 0,092 & 0,020 & 0,535 \\
\hline Atitudinal Nota Final & 0,849 & 0,114 & 0,865 & 0,066 & 0,520 \\
\hline Distribuição & 0,132 & 0,021 & 0,129 & 0,029 & 0,620 \\
\hline Avalia Funcionários & 0,100 & 0,051 & 0,106 & 0,039 & 0,650 \\
\hline Promove Integração & 0,102 & 0,038 & 0,108 & 0,017 & 0,419 \\
\hline Realiza Orientações & 0,100 & 0,040 & 0,100 & 0,017 & 0,955 \\
\hline Escala Mensal & 0,086 & 0,053 & 0,121 & 0,030 & 0,005 \\
\hline Interage com as Equipes & 0,103 & 0,032 & 0,111 & 0,021 & 0,320 \\
\hline Dimensionamento & 0,062 & 0,043 & 0,055 & 0,025 & 0,471 \\
\hline Gestão de Pessoas Nota Final & 0,685 & 0,168 & 0,729 & 0,109 & 0,322 \\
\hline Diagnóstico Médico & 0,258 & 0,092 & 0,280 & 0,062 & 0,390 \\
\hline Processos Fisiopatológicos & 0,276 & 0,096 & 0,261 & 0,046 & 0,461 \\
\hline SAE & 0,286 & 0,082 & 0,284 & 0,056 & 0,926 \\
\hline Evolução de Enfermagem & 0,291 & 0,074 & 0,269 & 0,046 & 0,213 \\
\hline Avalia Anotações & 0,282 & 0,081 & 0,284 & 0,092 & 0,948 \\
\hline Visita Diária & 0,359 & 0,043 & 0,320 & 0,051 & 0,006 \\
\hline Passagem de Plantão & 0,351 & 0,051 & 0,350 & 0,051 & 0,913 \\
\hline Ações de Enfermagem & 0,315 & 0,077 & 0,291 & 0,049 & 0,195 \\
\hline Gestão de Cuidados Nota Final & 2,418 & 0,441 & 2,339 & 0,248 & 0,419 \\
\hline Taxa de Ocupação & 0,363 & 0,038 & 0,360 & 0,042 & 0,821 \\
\hline Complexidade do Paciente & 0,330 & 0,074 & 0,324 & 0,062 & 0,757 \\
\hline Profissionais Disponíveis & 0,363 & 0,038 & 0,353 & 0,050 & 0,432 \\
\hline Indicadores & 0,271 & 0,101 & 0,223 & 0,050 & 0,027 \\
\hline Problemas & 0,284 & 0,098 & 0,288 & 0,055 & 0,866 \\
\hline Liderança & 0,238 & 0,097 & 0,255 & 0,025 & 0,339 \\
\hline Serviço de Limpeza & 0,351 & 0,051 & 0,364 & 0,025 & 0,234 \\
\hline Elaboração de Projetos & 0,323 & 0,108 & 0,293 & 0,109 & 0,347 \\
\hline Gestão Administrativa 1 Nota Final & 2,523 & 0,471 & 2,460 & 0,179 & 0,494 \\
\hline Impressos & 0,229 & 0,038 & 0,233 & 0,027 & 0,690 \\
\hline Relações Intersetoriais & 0,197 & 0,043 & 0,199 & 0,037 & 0,874 \\
\hline Materiais Permanentes & 0,176 & 0,032 & 0,188 & 0,051 & 0,364 \\
\hline Rotinas Diárias & 0,224 & 0,041 & 0,216 & 0,041 & 0,531 \\
\hline Gestão Administrativa 2 Nota Final & 0,826 & 0,092 & 0,837 & 0,119 & 0,728 \\
\hline Amplia Conhecimento & 0,181 & 0,032 & 0,180 & 0,034 & 0,933 \\
\hline Faz Pesquisa & 0,158 & 0,050 & 0,177 & 0,074 & 0,274 \\
\hline Explica os Dados Levantados & 0,154 & 0,049 & 0,171 & 0,074 & 0,326 \\
\hline Busca Relevante & 0,124 & 0,048 & 0,162 & 0,082 & 0,041 \\
\hline Amplia a Busca & 0,115 & 0,064 & 0,176 & 0,125 & 0,069 \\
\hline Desenvolvimento Pessoal Nota Fina & 0,733 & 0,173 & 0,867 & 0,301 & 0,048 \\
\hline
\end{tabular}


APÊNDICE 9: Distribuição das notas de avaliação do rodízio seis de acordo com o currículo cursado.

\begin{tabular}{|c|c|c|c|c|c|}
\hline & \multicolumn{2}{|c|}{$A(N=33)$} & \multicolumn{2}{|c|}{$\mathrm{B}(\mathrm{N}=18)$} & \\
\hline & MÉDIA & DP & MÉDIA & DP & VALOR $=p$ \\
\hline Apresentação Pessoal & 0,192 & 0,025 & 0,197 & 0,012 & 0,453 \\
\hline Assiduidade & 0,148 & 0,052 & 0,163 & 0,034 & 0,242 \\
\hline Pontualidade & 0,162 & 0,052 & 0,149 & 0,053 & 0,399 \\
\hline Orientação & 0,188 & 0,033 & 0,192 & 0,019 & 0,658 \\
\hline Material de Uso Pessoal & 0,173 & 0,045 & 0,192 & 0,019 & 0,042 \\
\hline Postura & 0,173 & 0,052 & 0,191 & 0,018 & 0,071 \\
\hline Construção de Relacionamentos & 0,191 & 0,029 & 0,196 & 0,013 & 0,527 \\
\hline Interesse & 0,183 & 0,037 & 0,170 & 0,033 & 0,208 \\
\hline Organização e Liderança & 0,132 & 0,046 & 0,160 & 0,023 & 0,006 \\
\hline Responsabilidade e Compromisso & 0,179 & 0,042 & 0,189 & 0,018 & 0,232 \\
\hline Bases Comportamentais & 1,721 & 0,219 & 1,798 & 0,100 & 0,094 \\
\hline Anatomia e Fisiologia & 0,167 & 0,051 & 0,172 & 0,031 & 0,677 \\
\hline Medicamentos & 0,173 & 0,055 & 0,172 & 0,031 & 0,971 \\
\hline Relaciona Exames & 0,168 & 0,050 & 0,191 & 0,046 & 0,113 \\
\hline Dinâmica da Unidade & 0,236 & 0,075 & 0,217 & 0,053 & 0,297 \\
\hline Programas de Saúde & 0,173 & 0,055 & 0,167 & 0,029 & 0,664 \\
\hline Organiza & 0,223 & 0,076 & 0,202 & 0,043 & 0,223 \\
\hline Prioridades & 0,236 & 0,075 & 0,210 & 0,059 & 0,173 \\
\hline Indicadores Epidemiológicos & 0,154 & 0,042 & 0,159 & 0,029 & 0,680 \\
\hline Analisa Dados & 0,205 & 0,073 & 0,196 & 0,048 & 0,624 \\
\hline Preenche Relatórios & 0,275 & 0,055 & 0,242 & 0,051 & 0,039 \\
\hline Conhecimentos Científicos Nota Final & 2,010 & 0,328 & 1,928 & 0,287 & 0,382 \\
\hline s Básicas & 0,339 & 0,109 & 0,302 & 0,079 & 168 \\
\hline Estado Clínico & 0,242 & 0,082 & 0,258 & 0,055 & 0,446 \\
\hline Documenta as Ações & 0,242 & 0,082 & 0,241 & 0,054 & 0,985 \\
\hline Consulta & 0,222 & 0,055 & 0,251 & 0,063 & 0,092 \\
\hline Analisa as Ações & 0,300 & 0,108 & 0,274 & 0,068 & 0,301 \\
\hline Organiza o Trabalho & 0,373 & 0,096 & 0,345 & 0,072 & 0,279 \\
\hline Passagem de Plantão & 0,350 & 0,111 & 0,359 & 0,077 & 0,715 \\
\hline Pratica Assistencial Nota Final & 2,066 & 0,381 & 2,030 & 0,321 & 0,733 \\
\hline Educação em Saúde & 0,185 & 0,068 & 0,185 & 0,040 & 0,993 \\
\hline Busca Extra Estágio & 0,199 & 0,074 & 0,172 & 0,052 & 0,167 \\
\hline Raciocínio Critico & 0,240 & 0,088 & 0,230 & 0,064 & 0,645 \\
\hline Apresentação do Trabalho & 0,321 & 0,054 & 0,318 & 0,030 & 0,824 \\
\hline Domínio & 0,321 & 0,054 & 0,318 & 0,029 & 0,823 \\
\hline Divisão das Tarefas & 0,334 & 0,031 & 0,314 & 0,045 & 0,070 \\
\hline Ações Educativas Nota Fina & 1,600 & 0,201 & 1,536 & 0,166 & 0,257 \\
\hline
\end{tabular}


APÊNDICE 10: Correlação da idade dos alunos e as subcategorias

\begin{tabular}{|c|c|c|}
\hline & Correlação & Valor-P \\
\hline Apresentação Pessoal - Rodízio 1 & $-0,005$ & 0,973 \\
\hline Assiduidade - Rodízio 1 & 0,143 & 0,316 \\
\hline Pontualidade - Rodízio 1 & 0,006 & 0,967 \\
\hline Postura Ética - Rodízio 1 & $-0,002$ & 0,990 \\
\hline Interesse - Rodízio 1 & 0,119 & 0,406 \\
\hline Comunicação - Rodízio 1 & 0,089 & 0,533 \\
\hline Orientação - Rodízio 1 & $-0,036$ & 0,804 \\
\hline Compromisso - Rodízio 1 & $-0,114$ & 0,424 \\
\hline Uso de Material Pessoal - Rodízio 1 & 0,293 & 0,037 \\
\hline Organização e Liderança - Rodízio 1 & $-0,123$ & 0,390 \\
\hline Relacionamento - Rodízio 1 & 0,198 & 0,163 \\
\hline Bases Comportamentais Nota Final - Rodízio 1 & 0,004 & 0,976 \\
\hline Anatomia e Fisiologia - Rodízio 1 & 0,124 & 0,388 \\
\hline Fisiopatologia - Rodízio 1 & 0,089 & 0,536 \\
\hline Medicamentos - Rodízio 1 & 0,064 & 0,657 \\
\hline Exames - Rodízio 1 & $-0,092$ & 0,523 \\
\hline Visitas - Rodízio 1 & 0,010 & 0,945 \\
\hline $\begin{array}{l}\text { Conhecimentos Nota Final - } \\
\text { Rodízio } 1\end{array}$ & 0,044 & 0,761 \\
\hline Reconhece a Clientela - Rodízio 1 & $-0,153$ & 0,284 \\
\hline Unidade - Rodízio 1 & 0,110 & 0,440 \\
\hline Técnica - Rodízio 1 & 0,358 & 0,010 \\
\hline SAE - Rodízio 1 & 0,244 & 0,085 \\
\hline Documenta - Rodízio 1 & 0,230 & 0,104 \\
\hline Cuidados Especializados - Rodízio 1 & 0,353 & 0,011 \\
\hline Cumpre Prazos - Rodízio 1 & $-0,100$ & 0,483 \\
\hline Ações de Enfermagem - Rodízio 1 & 0,119 & 0,404 \\
\hline Orientações - Rodízio 1 & 0,136 & 0,343 \\
\hline Efetividade Das Ações - Rodízio 1 & 0,203 & 0,153 \\
\hline Passagem De Plantão - Rodízio 1 & 0,237 & 0,094 \\
\hline Pratica Assistencial Nota Final - Rodízio 1 & 0,221 & 0,120 \\
\hline Estudo de Caso - Rodízio 1 & 0,106 & 0,459 \\
\hline Trabalhos - Rodízio 1 & 0,057 & 0,693 \\
\hline Domínio do Conteúdo - Rodízio 1 & 0,213 & 0,133 \\
\hline Reunião - Rodízio 1 & 0,090 & 0,529 \\
\hline Entrega - Rodízio 1 & 0,192 & 0,176 \\
\hline Amplia a Busca - Rodízio 1 & $-0,077$ & 0,593 \\
\hline Amplia Conhecimento - Rodízio 1 & 0,064 & 0,656 \\
\hline Trabalhos Nota Final - Rodízio 1 & 0,129 & 0,365 \\
\hline Apresentação Pessoal - Rodízio 2 & $-0,168$ & 0,239 \\
\hline Assiduidade - Rodízio 2 & 0,143 & 0,316 \\
\hline Pontualidade - Rodízio 2 & 0,006 & 0,967 \\
\hline Postura Ética - Rodízio 2 & $-0,002$ & 0,990 \\
\hline Interesse - Rodízio 2 & 0,119 & 0,406 \\
\hline Comunicação - Rodízio 2 & 0,089 & 0,533 \\
\hline Orientação - Rodízio 2 & 0,151 & 0,290 \\
\hline Compromisso - Rodízio 2 & $-0,056$ & 0,699 \\
\hline Uso de Material Pessoal - Rodízio 2 & 0,219 & 0,123 \\
\hline Organização e Liderança - Rodízio 2 & 0,187 & 0,188 \\
\hline Relacionamento - Rodízio 2 & 4 & $\bar{\star}$ \\
\hline Bases Comportamentais Nota Final - Rodízio 2 & 0,209 & 0,140 \\
\hline Anatomia e Fisiologia - Rodízio 2 & 0,177 & 0,214 \\
\hline Fisiopatologia - Rodízio 2 & 0,250 & 0,077 \\
\hline Medicamentos - Rodízio 2 & 0,263 & 0,062 \\
\hline
\end{tabular}




\begin{tabular}{|c|c|c|}
\hline Exames - Rodízio 2 & 0,235 & 0,097 \\
\hline Visitas - Rodízio 2 & 0,197 & 0,167 \\
\hline Conhecimentos Nota Final - Rodízio 2 & 0,238 & 0,093 \\
\hline Reconhece A Clientela- Rodízio 2 & 0,201 & 0,156 \\
\hline Unidade - Rodízio 2 & 0,122 & 0,392 \\
\hline Técnica - Rodízio 2 & 0,200 & 0,160 \\
\hline SAE - Rodízio 2 & 0,208 & 0,142 \\
\hline Documenta - Rodízio 2 & 0,145 & 0,311 \\
\hline Cuidados Especializados - Rodízio 2 & 0,215 & 0,131 \\
\hline Cumpre Prazos - Rodízio 2 & 0,110 & 0,444 \\
\hline Ações de Enfermagem - Rodízio 2 & 0,215 & 0,130 \\
\hline Orientações - Rodízio 2 & 0,242 & 0,087 \\
\hline Efetividade Das Ações - Rodízio 2 & 0,253 & 0,074 \\
\hline Passagem De Plantão - Rodízio 2 & 0,195 & 0,170 \\
\hline Prática Assistencial Nota Final - Rodízio 2 & 0,247 & 0,081 \\
\hline Estudo de Caso - Rodízio 2 & 0,055 & 0,704 \\
\hline Trabalhos - Rodízio 2 & 0,070 & 0,626 \\
\hline Domínio do Conteúdo - Rodízio 2 & $-0,217$ & 0,126 \\
\hline Reunião - Rodízio 2 & 0,112 & 0,434 \\
\hline Entrega - Rodízio 2 & $-0,143$ & 0,318 \\
\hline Amplia a Busca - Rodízio 2 & 0,178 & 0,212 \\
\hline Amplia Conhecimento - Rodízio 2 & 0,332 & 0,017 \\
\hline Trabalhos Nota Final - Rodízio 2 & 0,114 & 0,427 \\
\hline Apresentação Pessoal - Rodízio 3 & 0,256 & 0,070 \\
\hline Assiduidade - Rodízio 3 & 0,168 & 0,237 \\
\hline Pontualidade - Rodízio 3 & 0,072 & 0,618 \\
\hline Postura Ética - Rodízio 3 & 0,081 & 0,574 \\
\hline Interesse - Rodízio 3 & 0,298 & 0,034 \\
\hline Comunicação - Rodízio 3 & $-0,094$ & 0,510 \\
\hline Orientação - Rodízio 3 & 0,114 & 0,425 \\
\hline Compromisso - Rodízio 3 & 0,232 & 0,101 \\
\hline Uso de Material Pessoal - Rodízio 3 & 0,262 & 0,063 \\
\hline Organização e Liderança - Rodízio 3 & 0,223 & 0,116 \\
\hline Relacionamento - Rodízio 3 & 0,171 & 0,231 \\
\hline Bases Comportamentais Nota Final - Rodízio 3 & 0,258 & 0,068 \\
\hline Anatomia e Fisiologia - Rodízio 3 & $-0,095$ & 0,508 \\
\hline Fisiopatologia - Rodízio 3 & 0,100 & 0,483 \\
\hline Medicamentos - Rodízio 3 & 0,040 & 0,778 \\
\hline Exames - Rodízio 3 & 0,143 & 0,316 \\
\hline Visitas - Rodízio 3 & 0,061 & 0,670 \\
\hline Conhecimentos Nota Final - Rodízio 3 & 0,078 & 0,588 \\
\hline Reconhece a Clientela- Rodízio 3 & $-0,140$ & 0,328 \\
\hline Unidade - Rodízio 3 & 0,203 & 0,153 \\
\hline Técnica - Rodízio 3 & 0,270 & 0,055 \\
\hline SAE - Rodízio 3 & 0,194 & 0,173 \\
\hline Documenta - Rodízio 3 & 0,203 & 0,152 \\
\hline Cuidados Especializados - Rodízio 3 & $-0,152$ & 0,288 \\
\hline Cumpre Prazos - Rodízio 3 & 0,282 & 0,045 \\
\hline Ações de Enfermagem - Rodízio 3 & 0,181 & 0,204 \\
\hline Orientações - Rodízio 3 & 0,032 & 0,823 \\
\hline Efetividade das Ações - Rodízio 3 & $-0,099$ & 0,489 \\
\hline Passagem de Plantão - Rodízio 3 & 0,165 & 0,247 \\
\hline Pratica Assistencial Nota Final - Rodízio 3 & 0,144 & 0,313 \\
\hline Estudo de Caso - Rodízio 3 & $-0,018$ & 0,899 \\
\hline Trabalhos - Rodízio 3 & 0,128 & 0,373 \\
\hline Domínio do Conteúdo - Rodízio 3 & 0,134 & 0,347 \\
\hline Reunião - Rodízio 3 & $-0,183$ & 0,198 \\
\hline
\end{tabular}




\begin{tabular}{|c|c|c|}
\hline Entrega - Rodízio 3 & 0,043 & 0,765 \\
\hline Amplia a Busca - Rodízio 3 & $-0,161$ & 0,259 \\
\hline Amplia Conhecimento - Rodízio 3 & 0,048 & 0,738 \\
\hline Trabalhos Nota Final - Rodízio 3 & $-0,013$ & 0,930 \\
\hline Apresentação Pessoal - Rodízio 4 & * & * \\
\hline Assiduidade - Rodízio 4 & 0,081 & 0,570 \\
\hline Pontualidade - Rodízio 4 & 0,016 & 0,913 \\
\hline Orientação - Rodízio 4 & $-0,176$ & 0,217 \\
\hline Material de Uso Pessoal - Rodízio 4 & $-0,023$ & 0,870 \\
\hline Postura - Rodízio 4 & 0,006 & 0,968 \\
\hline $\begin{array}{l}\text { Construção de Relacionamentos - } \\
\text { Rodízio } 4\end{array}$ & $-0,304$ & 0,030 \\
\hline Interesse - Rodízio 4 & 0,363 & 0,009 \\
\hline Organização e Liderança - Rodízio 4 & $-0,101$ & 0,479 \\
\hline Responsabilidade e Compromisso - Rodízio 4 & 0,027 & 0,851 \\
\hline Bases Comportamentais Nota Final - Rodízio 4 & 0,028 & 0,847 \\
\hline Anatomia e Fisiologia - Rodízio 4 & 0,325 & 0,020 \\
\hline Medicamentos - Rodízio 4 & 0,302 & 0,031 \\
\hline Relaciona Exames - Rodízio 4 & 0,014 & 0,920 \\
\hline Dinâmica Da Unidade - Rodízio 4 & 0,100 & 0,487 \\
\hline Programas de Saúde - Rodízio 4 & * & * \\
\hline Planeja e Organiza - Rodízio 4 & 0,126 & 0,379 \\
\hline Prioridades - Rodízio 4 & 0,163 & 0,254 \\
\hline $\begin{array}{l}\text { Indicadores Epidemiológicos - } \\
\text { Rodízio } 4\end{array}$ & * & * \\
\hline Analisa Dados - Rodízio 4 & $-0,148$ & 0,300 \\
\hline Preenche Relatórios - Rodízio 4 & 0,142 & 0,319 \\
\hline Conhecimentos Científicos Nota Final - Rodízio 4 & 0,277 & 0,049 \\
\hline Técnicas Básicas - Rodízio 4 & 0,182 & 0,202 \\
\hline Estado Clinico - Rodízio 4 & 0,040 & 0,781 \\
\hline Documenta As Ações - Rodízio 4 & $-0,001$ & 0,995 \\
\hline Consulta - Rodízio 4 & 0,016 & 0,909 \\
\hline Analisa as Ações - Rodízio 4 & 0,114 & 0,427 \\
\hline Organiza o Trabalho - Rodízio 4 & 0,211 & 0,137 \\
\hline Passagem de Plantão - Rodízio 4 & 0,122 & 0,395 \\
\hline Pratica Assistencial Nota Final - Rodízio 4 & 0,176 & 0,217 \\
\hline Educação em Saúde - Rodízio 4 & 0,138 & 0,334 \\
\hline Busca Extra Estágio - Rodízio 4 & 0,158 & 0,268 \\
\hline Raciocínio Crítico - Rodízio 4 & 0,062 & 0,665 \\
\hline Apresentação do Trabalho - Rodízio 4 & $-0,028$ & 0,846 \\
\hline Domínio - Rodízio 4 & 0,093 & 0,518 \\
\hline Divisão das Tarefas - Rodízio 4 & $-0,262$ & 0,064 \\
\hline $\begin{array}{l}\text { Ações Educativas Nota Final - } \\
\text { Rodízio } 4\end{array}$ & 0,057 & 0,689 \\
\hline Apresentação Pessoal - Rodízio 5 & 0,170 & 0,233 \\
\hline Assiduidade - Rodízio 5 & 0,277 & 0,049 \\
\hline Pontualidade - Rodízio 5 & 0,066 & 0,643 \\
\hline Postura Ética - Rodízio 5 & 0,006 & 0,964 \\
\hline Interesse - Rodízio 5 & $-0,013$ & 0,926 \\
\hline Comunicação - Rodízio 5 & $-0,220$ & 0,121 \\
\hline Orientação - Rodízio 5 & $-0,254$ & 0,072 \\
\hline Compromissos - Rodízio 5 & 0,025 & 0,864 \\
\hline Organização - Rodízio 5 & 0,010 & 0,943 \\
\hline Relaciona Mento - Rodízio 5 & $-0,284$ & 0,044 \\
\hline Atitudinal Nota Final - Rodízio 5 & $-0,045$ & 0,756 \\
\hline Distribuição - Rodízio 5 & 0,094 & 0,510 \\
\hline Avalia Funcionários - Rodízio 5 & $-0,177$ & 0,215 \\
\hline
\end{tabular}




\begin{tabular}{|c|c|c|}
\hline Promove Integração - Rodízio 5 & 0,062 & 0,667 \\
\hline Realiza Orientações - Rodízio 5 & $-0,093$ & 0,514 \\
\hline Escala Mensal - Rodízio 5 & $-0,292$ & 0,037 \\
\hline Interage Com As Equipes - Rodízio 5 & $-0,075$ & 0,603 \\
\hline Dimensiona Mento - Rodízio 5 & $-0,165$ & 0,248 \\
\hline Gestão de Pessoas Nota Final - Rodízio 5 & $-0,198$ & 0,163 \\
\hline Diagnóstico Médico - Rodízio 5 & $-0,027$ & 0,849 \\
\hline $\begin{array}{l}\text { Processos Fisiopatológicos - } \\
\text { Rodízio } 5\end{array}$ & $-0,011$ & 0,938 \\
\hline SAE - Rodízio 5 & $-0,064$ & 0,658 \\
\hline Evolução De Enfermagem - Rodízio 5 & 0,095 & 0,506 \\
\hline Avalia Anotações - Rodízio 5 & $-0,140$ & 0,326 \\
\hline Visita Diária - Rodízio 5 & 0,035 & 0,806 \\
\hline Passagem De Plantão - Rodízio 5 & 0,097 & 0,498 \\
\hline Ações De Enfermagem - Rodízio 5 & $-0,208$ & 0,143 \\
\hline Gestão de Cuidados Nota Final - Rodízio 5 & $-0,055$ & 0,703 \\
\hline Taxa De Ocupação - Rodízio 5 & 0,025 & 0,863 \\
\hline Complexidade do Paciente - Rodízio 5 & 0,045 & 0,754 \\
\hline Profissionais Disponíveis - Rodízio 5 & 0,088 & 0,540 \\
\hline Indicadores - Rodízio 5 & 0,093 & 0,517 \\
\hline Problemas - Rodízio 5 & 0,092 & 0,520 \\
\hline Liderança - Rodízio 5 & $-0,066$ & 0,644 \\
\hline Serviço de Limpeza - Rodízio 5 & 0,248 & 0,079 \\
\hline Elaboração de Projetos - Rodízio 5 & 0,003 & 0,983 \\
\hline Gestão Administrativa 1 Nota Final - Rodízio 5 & 0,076 & 0,594 \\
\hline Impressos - Rodízio 5 & 0,075 & 0,602 \\
\hline Relações Intersetoriais - Rodízio 5 & 0,265 & 0,060 \\
\hline Materiais Permanentes - Rodízio 5 & 0,174 & 0,223 \\
\hline Rotinas Diárias - Rodízio 5 & 0,012 & 0,933 \\
\hline Gestão Administrativa 2 Nota Final & 0,204 & 0,151 \\
\hline Amplia Conhecimento - Rodízio 5 & 0,041 & 0,774 \\
\hline Faz Pesquisa - Rodízio 5 & $-0,047$ & 0,741 \\
\hline Explica os Dados Levantados - Rodízio 5 & $-0,080$ & 0,579 \\
\hline Busca Relevante - Rodízio 5 & $-0,218$ & 0,125 \\
\hline Amplia a Busca - Rodízio 5 & $-0,129$ & 0,368 \\
\hline Desenvolvimento Pessoal Nota Final - Rodízio 5 & $-0,138$ & 0,333 \\
\hline Apresentação Pessoal - Rodízio 6 & $-0,081$ & 0,571 \\
\hline Assiduidade - Rodízio 6 & 0,148 & 0,299 \\
\hline Pontualidade - Rodízio 6 & $-0,174$ & 0,223 \\
\hline Orientação - Rodízio 6 & 0,032 & 0,822 \\
\hline Material de Uso Pessoal - Rodízio 6 & 0,166 & 0,246 \\
\hline Postura - Rodízio 6 & $-0,016$ & 0,909 \\
\hline Construção de Relacionamentos - Rodízio 6 & 0,101 & 0,483 \\
\hline Interesse - Rodízio 6 & 0,341 & 0,014 \\
\hline Organização e Liderança - Rodízio 6 & 0,135 & 0,344 \\
\hline Responsabilidade e Compromisso - Rodízio 6 & 0,050 & 0,727 \\
\hline Bases Comportamentais Nota Final - Rodízio 6 & 0,132 & 0,354 \\
\hline Anatomia e Fisiologia - Rodízio 6 & 0,168 & 0,239 \\
\hline Medicamentos - Rodízio 6 & 0,103 & 0,474 \\
\hline Relaciona Exames - Rodízio 6 & 0,283 & 0,044 \\
\hline Dinâmica da Unidade - Rodízio 6 & 0,118 & 0,408 \\
\hline Programas de Saúde - Rodízio 6 & $-0,020$ & 0,888 \\
\hline Planeja e Organiza - Rodízio 6 & 0,177 & 0,215 \\
\hline Prioridades - Rodízio 6 & $-0,047$ & 0,746 \\
\hline $\begin{array}{l}\text { Indicadores Epidemiológicos - } \\
\text { Rodízio } 6\end{array}$ & 0 & 0,088 \\
\hline Analisa dados - Rodízio 6 & 0,193 & 0,175 \\
\hline
\end{tabular}




\begin{tabular}{|l|c|c|}
\hline Preenche Relatórios - Rodízio 6 & $-0,119$ & 0,405 \\
\hline Conhecimentos Científicos Nota Final - Rodízio 6 & 0,182 & 0,202 \\
\hline Técnicas Básicas - Rodízio 6 & 0,031 & 0,832 \\
\hline Estado Clinico - Rodízio 6 & 0,097 & 0,498 \\
\hline Documenta As Ações - Rodízio 6 & 0,073 & 0,608 \\
\hline Consulta - Rodízio 6 & 0,020 & 0,888 \\
\hline Analisa as Ações - Rodízio 6 & 0,179 & 0,208 \\
\hline Organiza o Trabalho - Rodízio 6 & 0,111 & 0,440 \\
\hline Passagem de Plantão - Rodízio 6 & 0,286 & 0,042 \\
\hline Pratica Assistencial Nota Final - Rodízio 6 & 0,201 & 0,157 \\
\hline Educação Em Saúde - Rodízio 6 & 0,443 & 0,001 \\
\hline Busca Extra Estágio - Rodízio 6 & 0,276 & 0,050 \\
\hline Raciocínio Critico - Rodízio 6 & 0,520 & 0,000 \\
\hline Apresentação do Trabalho - Rodízio 6 & 0,059 & 0,680 \\
\hline Domínio - Rodízio 6 & 0,162 & 0,257 \\
\hline Divisão das Tarefas - Rodízio 6 & 0,042 & 0,771 \\
\hline Ações Educativas Nota Final - & 0,519 & 0,000 \\
\hline Rodízio 6 & 0,224 & 0,114 \\
\hline Média Final & & \\
\hline * Variáveis Com. São Constantes. & & \\
(Todas Notas Iguais). & & \\
\hline
\end{tabular}


APÊNDICE 11- Distribuição da comparação das médias segundo o gênero do estudante

\begin{tabular}{|c|c|c|c|c|c|}
\hline & & & $(\mathrm{N}$ & ino & \\
\hline & Média & DP & Média & DP & Valor $=p$ \\
\hline Apresentação Pessoal - Rodízio 1 & 0,678 & 0,704 & 0,961 & 0,900 & 0,452 \\
\hline $\begin{array}{l}\text { Assiduidade - } \\
\text { Rodízio } 1\end{array}$ & 0,135 & 0,036 & 0,133 & 0,012 & 0,884 \\
\hline Pontualidade - Rodízio 1 & 0,135 & 0,037 & 0,107 & 0,041 & 0,150 \\
\hline Postura Ética - Rodízio 1 & 0,179 & 0,010 & 0,182 & 0,000 & 0,557 \\
\hline Interesse- Rodízio 1 & 0,165 & 0,028 & 0,141 & 0,028 & 0,107 \\
\hline Comunicação - Rodízio 1 & 0,132 & 0,022 & 0,134 & 0,014 & 0,863 \\
\hline $\begin{array}{l}\text { Orientação- } \\
\text { Rodízio } 1\end{array}$ & 0,170 & 0,021 & 0,168 & 0,028 & 0,901 \\
\hline Compromisso - Rodízio 1 & 0,169 & 0,024 & 0,182 & 0,000 & 0,001 \\
\hline Uso de Material Pessoal - Rodízio 1 & 0,171 & 0,021 & 0,147 & 0,026 & 0,032 \\
\hline Organização e Liderança - Rodízio 1 & 0,151 & 0,099 & 0,139 & 0,013 & 0,809 \\
\hline Relacionamento - Rodízio 1 & 0,164 & 0,023 & 0,147 & 0,026 & 0,150 \\
\hline $\begin{array}{l}\text { Bases Comportamentais Nota Final - } \\
\text { Rodízio } 1\end{array}$ & 2,249 & 0,690 & 2,439 & 1,005 & 0,611 \\
\hline Anatomia e Fisiologia - Rodízio 1 & 0,376 & 0,084 & 0,388 & 0,103 & 0,797 \\
\hline Fisiopatologia - Rodízio 1 & 0,388 & 0,090 & 0,388 & 0,103 & 0,996 \\
\hline Medicamentos - Rodízio 1 & 0,340 & 0,097 & 0,375 & 0,166 & 0,514 \\
\hline Exames - Rodízio 1 & 0,366 & 0,094 & 0,413 & 0,144 & 0,372 \\
\hline Visitas - Rodízio 1 & 0,424 & 0,083 & 0,363 & 0,075 & 0,157 \\
\hline Conhecimentos Nota Final - Rodízio 1 & 1,895 & 0,374 & 1,925 & 0,555 & 0,881 \\
\hline Reconhece a Clientela- Rodízio 1 & 0,231 & 0,045 & 0,225 & 0,057 & 0,772 \\
\hline Unidade - Rodízio 1 & 0,188 & 0,029 & 0,200 & 0,028 & 0,460 \\
\hline Técnica - Rodízio 1 & 0,206 & 0,041 & 0,212 & 0,047 & 0,772 \\
\hline SAE - Rodízio 1 & 0,173 & 0,034 & 0,187 & 0,025 & 0,423 \\
\hline $\begin{array}{l}\text { Documenta - } \\
\text { Rodízio } 1\end{array}$ & 0,194 & 0,035 & 0,200 & 0,028 & 0,766 \\
\hline Cuidados Especializados- Rodízio 1 & 0,208 & 0,047 & 0,212 & 0,047 & 0,865 \\
\hline Cumpre Prazos - Rodízio 1 & 0,243 & 0,044 & 0,249 & 0,050 & 0,779 \\
\hline Ações de Enfermagem - Rodízio 1 & 0,183 & 0,028 & 0,187 & 0,025 & 0,769 \\
\hline $\begin{array}{l}\text { Orientações - } \\
\text { Rodízio } 1\end{array}$ & 0,188 & 0,026 & 0,187 & 0,025 & 0,982 \\
\hline Efetividade das Ações - Rodízio 1 & 0,178 & 0,028 & 0,172 & 0,046 & 0,646 \\
\hline Passagem de Plantão - Rodízio 1 & 0,201 & 0,039 & 0,200 & 0,050 & 0,956 \\
\hline Pratica Assistencial Nota Final - Rodízio 1 & 2,193 & 0,273 & 2,230 & 0,359 & 0,802 \\
\hline Estudo de Caso - Rodízio 1 & 0,262 & 0,043 & 0,258 & 0,056 & 0,862 \\
\hline Trabalhos- Rodízio 1 & 0,242 & 0,058 & 0,244 & 0,053 & 0,937 \\
\hline Domínio do Conteúdo- Rodízio 1 & 0,232 & 0,053 & 0,217 & 0,053 & 0,584 \\
\hline Reunião - Rodízio 1 & 0,201 & 0,046 & 0,174 & 0,046 & 0,276 \\
\hline Entrega - Rodízio 1 & 0,284 & 0,016 & 0,286 & 0,000 & 0,774 \\
\hline Amplia a Busca - Rodízio 1 & 0,203 & 0,040 & 0,175 & 0,000 & 0,000 \\
\hline Amplia Conhecimento - Rodízio 1 & 0,245 & 0,046 & 0,203 & 0,056 & 0,089 \\
\hline Trabalhos Nota Final - Rodízio 1 & 1,668 & 0,208 & 1,557 & 0,078 & 0,297 \\
\hline Apresentação Pessoal - Rodízio 2 & 0,180 & 0,011 & 0,182 & 0,000 & 0,681 \\
\hline $\begin{array}{l}\text { Assiduidade - } \\
\text { Rodízio } 2\end{array}$ & 0,135 & 0,036 & 0,133 & 0,012 & 0,884 \\
\hline Pontualidade - Rodízio 2 & 0,135 & 0,037 & 7 & 0,041 & 0,150 \\
\hline Postura Ética - Rodízio 2 & 0,179 & 0,010 & 0,182 & 0,000 & 0,557 \\
\hline Interesse - Rodízio 2 & 0,165 & 0,028 & 0,141 & 0,028 & 0,107 \\
\hline Comunicação - Rodízio 2 & 0,132 & 0,022 & 0,134 & 0,014 & 0,863 \\
\hline $\begin{array}{l}\text { Orientação - } \\
\text { Rodízio } 2\end{array}$ & 0,181 & 0,008 & 0,182 & 0,000 & 0,774 \\
\hline Compromisso - Rodízio 2 & 0,181 & 0,005 & 0,182 & 0,000 & 0,774 \\
\hline Uso de Material Pessoal - 1 & 0,173 & 0,020 & 0,168 & 0,028 & 0,651 \\
\hline Organização e Liderança - Rodízio 2 & 0,152 & 0,027 & 0,155 & 0,032 & 0,867 \\
\hline
\end{tabular}




\begin{tabular}{|c|c|c|c|c|c|}
\hline Relacionamento - Rodízio 2 & 0,182 & 0,000 & 0,182 & 0,000 & 1,000 \\
\hline $\begin{array}{l}\text { Bases Comportamentais Nota Final - } \\
\text { Rodízio } 2\end{array}$ & 1,795 & 0,089 & 1,747 & 0,115 & 0,314 \\
\hline Anatomia e Fisiologia - Rodízio 2 & 0,379 & 0,089 & 0,350 & 0,058 & 0,522 \\
\hline Fisiopatologia - Rodízio 2 & 0,366 & 0,087 & 0,350 & 0,058 & 0,713 \\
\hline Medicamentos - Rodízio 2 & 0,347 & 0,078 & 0,375 & 0,096 & 0,506 \\
\hline Exames - Rodízio 2 & 0,352 & 0,092 & 0,375 & 0,096 & 0,627 \\
\hline Visitas - Rodízio 2 & 0,359 & 0,088 & 0,375 & 0,096 & 0,732 \\
\hline $\begin{array}{l}\text { Conhecimentos } \\
\text { Nota Final - } \\
\text { Rodízio } 2\end{array}$ & 1,804 & 0,408 & 1,825 & 0,395 & 0,921 \\
\hline Reconhece a Clientela- Rodízio 2 & 0,174 & 0,025 & 0,163 & 0,043 & 0,405 \\
\hline Unidade - Rodízio 2 & 0,181 & 0,029 & 0,163 & 0,043 & 0,262 \\
\hline Técnica - Rodízio 2 & 0,186 & 0,040 & 0,163 & 0,048 & 0,277 \\
\hline SAE - Rodízio 2 & 0,167 & 0,032 & 0,150 & 0,035 & 0,326 \\
\hline $\begin{array}{l}\text { Documenta - } \\
\text { Rodízio } 2\end{array}$ & 0,169 & 0,036 & 0,150 & 0,035 & 0,317 \\
\hline Cuidados Especializados- Rodízio 2 & 0,185 & 0,042 & 0,163 & 0,048 & 0,307 \\
\hline Cumpre Prazos - Rodízio 2 & 0,177 & 0,028 & 0,169 & 0,047 & 0,607 \\
\hline Ações de Enfermagem - Rodízio 2 & 0,173 & 0,030 & 0,156 & 0,043 & 0,296 \\
\hline $\begin{array}{l}\text { Orientações - } \\
\text { Rodízio } 2\end{array}$ & 0,168 & 0,029 & 0,163 & 0,043 & 0,736 \\
\hline Efetividade das Ações - Rodízio 2 & 0,173 & 0,029 & 0,150 & 0,041 & 0,156 \\
\hline Passagem de Plantão - Rodízio 2 & 0,178 & 0,032 & 0,163 & 0,043 & 0,352 \\
\hline Pratica Assistencial Nota Final - Rodízio 2 & 1,930 & 0,263 & 1,750 & 0,460 & 0,222 \\
\hline Estudo de Caso - Rodízio 2 & 0,280 & 0,022 & 0,286 & 0,000 & 0,585 \\
\hline Trabalhos- Rodízio 2 & 0,248 & 0,052 & 0,286 & 0,000 & 0,000 \\
\hline Domínio do Conteúdo- Rodízio 2 & 0,256 & 0,047 & 0,265 & 0,043 & 0,724 \\
\hline Reunião - Rodízio 2 & 0,254 & 0,047 & 0,203 & 0,056 & 0,046 \\
\hline Entrega - Rodízio 2 & 0,268 & 0,040 & 0,286 & 0,000 & 0,004 \\
\hline Amplia a Busca - Rodízio 2 & 0,249 & 0,050 & 0,258 & 0,056 & 0,715 \\
\hline Amplia Conhecimento - Rodízio 2 & 0,248 & 0,050 & 0,209 & 0,053 & 0,136 \\
\hline Trabalhos Nota Final - Rodízio 2 & 1,802 & 0,182 & 1,793 & 0,161 & 0,916 \\
\hline Apresentação Pessoal - Rodízio 3 & 0,166 & 0,033 & 0,153 & 0,034 & 0,431 \\
\hline $\begin{array}{l}\text { Assiduidade- } \\
\text { Rodízio } 3\end{array}$ & 0,134 & 0,050 & 0,155 & 0,032 & 0,427 \\
\hline Pontualidade- Rodízio 3 & 0,135 & 0,039 & 0,100 & 0,067 & 0,111 \\
\hline Postura Ética - Rodízio 3 & 0,172 & 0,026 & 0,155 & 0,032 & 0,209 \\
\hline Interesse- Rodízio 3 & 0,158 & 0,046 & 0,153 & 0,034 & 0,838 \\
\hline Comunicação - Rodízio 3 & 0,136 & 0,035 & 0,107 & 0,041 & 0,124 \\
\hline $\begin{array}{l}\text { Orientação - } \\
\text { Rodízio } 3\end{array}$ & 0,157 & 0,037 & 0,148 & 0,041 & 0,627 \\
\hline Compromisso - Rodízio 3 & 0,163 & 0,043 & 0,155 & 0,032 & 0,697 \\
\hline Uso de Material Pessoal - Rodízio 3 & 0,170 & 0,026 & 0,182 & 0,000 & 0,002 \\
\hline Organização e Liderança - Rodízio 3 & 0,135 & 0,045 & 0,122 & 0,054 & 0,586 \\
\hline Relacionamento - Rodízio 3 & 0,173 & 0,024 & 0,174 & 0,016 & 0,933 \\
\hline $\begin{array}{l}\text { Bases Comportamentais Nota Final - } \\
\text { Rodízio } 3\end{array}$ & 1,698 & 0,266 & 1,601 & 0,127 & 0,476 \\
\hline Anatomia e Fisiologia - Rodízio 3 & 0,362 & 0,103 & 0,325 & 0,096 & 0,496 \\
\hline Fisiopatologia - Rodízio 3 & 0,283 & 0,146 & 0,325 & 0,096 & 0,465 \\
\hline Medicamentos - Rodízio 3 & 0,339 & 0,125 & 0,325 & 0,096 & 0,825 \\
\hline Exames - Rodízio 3 & 0,333 & 0,138 & 0,325 & 0,096 & 0,911 \\
\hline Visitas - Rodízio 3 & 0,391 & 0,131 & 0,375 & 0,050 & 0,806 \\
\hline Conhecimentos Nota Final - Rodízio 3 & 1,708 & 0,480 & 1,675 & 0,395 & 0,893 \\
\hline Reconhece a Clientela- Rodízio 3 & 0,235 & 0,096 & 0,381 & 0,283 & 0,381 \\
\hline Unidade - Rodízio 3 & 0,237 & 0,048 & 0,211 & 0,076 & 0,312 \\
\hline Técnica - Rodízio 3 & 0,204 & 0,054 & 0,164 & 0,100 & 0,186 \\
\hline SAE - Rodízio 3 & 0,169 & 0,043 & 0,111 & 0,074 & 0,217 \\
\hline $\begin{array}{l}\text { Documenta - } \\
\text { Rodízio } 3\end{array}$ & 0,187 & 0,050 & 0,155 & 0,095 & 0,251 \\
\hline Cuidados Especializados- Rodízio 3 & 0,215 & 0,101 & 0,356 & 0,300 & 0,418 \\
\hline Cumpre Prazos - Rodízio 3 & 0,210 & 0,059 & 0,196 & 0,102 & 0,662 \\
\hline Ações de Enfermagem - Rodízio 3 & 0,195 & 0,062 & 0,171 & 0,087 & 0,473 \\
\hline
\end{tabular}




\begin{tabular}{|c|c|c|c|c|c|}
\hline $\begin{array}{l}\text { Orientações - } \\
\text { Rodízio } 3\end{array}$ & 0,172 & 0,044 & 0,194 & 0,038 & 0,334 \\
\hline Efetividade das Ações - Rodízio 3 & 0,177 & 0,058 & 0,194 & 0,038 & 0,574 \\
\hline Passagem de Plantão - Rodízio 3 & 0,217 & 0,060 & 0,158 & 0,111 & 0,079 \\
\hline Pratica Assistencial Nota Final - Rodízio 3 & 2,219 & 0,309 & 2,289 & 0,428 & 0,676 \\
\hline Estudo De Caso - Rodízio 3 & 0,206 & 0,071 & 0,196 & 0,111 & 0,792 \\
\hline Trabalhos- Rodízio 3 & 0,193 & 0,061 & 0,123 & 0,061 & 0,031 \\
\hline Domínio do Conteúdo- Rodízio 3 & 0,163 & 0,066 & 0,174 & 0,092 & 0,762 \\
\hline Reunião - Rodízio 3 & 0,192 & 0,071 & 0,142 & 0,107 & 0,199 \\
\hline Entrega - Rodízio 3 & 0,259 & 0,057 & 0,232 & 0,062 & 0,367 \\
\hline Amplia a Busca - Rodízio 3 & 0,205 & 0,071 & 0,145 & 0,108 & 0,127 \\
\hline Amplia Conhecimento - Rodízio 3 & 0,214 & 0,059 & 0,155 & 0,099 & 0,073 \\
\hline Trabalhos Nota Final - Rodízio 3 & 1,432 & 0,339 & 1,166 & 0,429 & 0,146 \\
\hline Apresentação Pessoal - Rodízio 4 & 0,200 & 0,000 & 0,200 & 0,000 & 1,000 \\
\hline $\begin{array}{l}\text { Assiduidade - } \\
\text { Rodízio } 4\end{array}$ & 0,163 & 0,047 & 0,193 & 0,015 & 0,016 \\
\hline Pontualidade - Rodízio 4 & 0,146 & 0,052 & 0,138 & 0,048 & 0,761 \\
\hline $\begin{array}{l}\text { Orientação - } \\
\text { Rodízio } 4\end{array}$ & 0,195 & 0,021 & 0,175 & 0,050 & 0,490 \\
\hline Material de Uso Pessoal - Rodízio 4 & 0,189 & 0,031 & 0,200 & 0,000 & 0,502 \\
\hline Postura - Rodízio 4 & 0,164 & 0,049 & 0,150 & 0,058 & 0,592 \\
\hline $\begin{array}{l}\text { Construção de Relacionamentos- Rodízio } \\
4\end{array}$ & 0,180 & 0,040 & 0,175 & 0,050 & 0,822 \\
\hline Interesse- Rodízio 4 & 0,149 & 0,048 & 0,138 & 0,048 & 0,637 \\
\hline Organização e Liderança- Rodízio 4 & 0,106 & 0,025 & 0,113 &, 025 & 0,637 \\
\hline $\begin{array}{l}\text { Responsabilidade e Compromisso - } \\
\text { Rodízio } 4\end{array}$ & 0,177 & 0,042 & 0,175 & 0,029 & 0,941 \\
\hline $\begin{array}{l}\text { Bases Comportamentais Nota Final - } \\
\text { Rodízio } 4\end{array}$ & 1,669 & 0,129 & 1,655 & 0,114 & 0,839 \\
\hline Anatomia e Fisiologia- Rodízio 4 & 0,188 & 0,064 & 0,178 & 0,084 & 0,758 \\
\hline Medicamentos - Rodízio 4 & 0,159 & 0,062 & 0,168 & 0,096 & 0,796 \\
\hline Relaciona Exames - Rodízio 4 & 0,151 & 0,025 & 0,148 & 0,061 & 0,905 \\
\hline Dinâmica da Unidade - Rodízio 4 & 0,224 & 0,075 & 0,205 & 0,071 & 0,620 \\
\hline Programas de Saúde - Rodízio 4 & 0,150 & 0,000 & 0,150 & 0,000 & 1,000 \\
\hline Planeja e Organiza- Rodízio 4 & 0,244 & 0,069 & 0,280 & 0,040 & 0,169 \\
\hline $\begin{array}{l}\text { Prioridades - } \\
\text { Rodízio } 4\end{array}$ & 0,259 & 0,064 & 0,243 & 0,072 & 0,632 \\
\hline Indicadores Epidemiológicos- Rodízio 4 & 0,150 & 0,000 & 0,150 & 0,000 & 1,000 \\
\hline Analisa Dados - Rodízio 4 & 0,154 & 0,029 & 0,150 & 0,000 & 0,759 \\
\hline Preenche Relatórios- Rodízio 4 & 0,207 & 0,074 & 0,263 & 0,075 & 0,156 \\
\hline $\begin{array}{l}\text { Conhecimentos Científicos Nota Final - } \\
\text { Rodízio } 4\end{array}$ & 1,887 & 0,255 & 1,933 & 0,425 & 0,744 \\
\hline Técnicas Básicas - Rodízio 4 & 276 & 05 & 0,224 & 069 & 0,235 \\
\hline Estado Clinico - Rodízio 4 & 0,331 & 0,105 & 0,238 & 0,055 & 0,030 \\
\hline Documenta As Ações - Rodízio 4 & 0,252 & 0,087 & 0,320 & 0,127 & 0,156 \\
\hline Consulta - Rodízio 4 & 0,213 & 0,040 & 0,196 & 0,028 & 0,413 \\
\hline Analisa as Ações - Rodízio 4 & 0,241 & 0,080 & 0,264 & 0,111 & 0,606 \\
\hline Organiza o Trabalho - Rodízio 4 & 0,321 & 0,108 & 0,348 & 0,105 & 0,641 \\
\hline Passagem de Plantão - Rodízio 4 & 0,328 & 0,110 & 0,320 & 0,127 & 0,895 \\
\hline Pratica Assistencial Nota Final - Rodízio 4 & 1,963 & 0,388 & 1,909 & 0,469 & 0,792 \\
\hline Educação em Saúde - Rodízio 4 & 0,314 & 0,067 & 0,238 & 0,078 & 0,034 \\
\hline Busca Extra Estágio - Rodízio 4 & 0,279 & 0,087 & 0,250 & 0,104 & 0,528 \\
\hline Raciocínio Critico - Rodízio 4 & 0,281 & 0,085 & 0,228 & 0,086 & 0,234 \\
\hline Apresentação do Trabalho - Rodízio 4 & 0,319 & 0,062 & 0,327 & 0,024 & 0,812 \\
\hline Domínio - Rodízio 4 & 0,321 & 0,060 & 0,256 & 0,095 & 0,052 \\
\hline Divisão das Tarefas - Rodízio 4 & 0,322 & 0,063 & 0,311 & 0,054 & 0,748 \\
\hline Ações Educativas Nota Final - Rodízio 4 & 1,836 & 0,282 & 1,609 & 0,395 & 0,139 \\
\hline Apresentação Pessoal - Rodízio 5 & 0,100 & 0,003 & 0,081 & 0,039 & 0,399 \\
\hline $\begin{array}{l}\text { Assiduidade - } \\
\text { Rodízio } 5\end{array}$ & 0,080 & 0,021 & 0,072 & 0,037 & 0,482 \\
\hline Pontualidade- Rodízio 5 & 0,074 & 0,029 & 0,067 & 0,033 & 0,680 \\
\hline Postura Ética - Rodízio 5 & 0,099 & 0,005 & 0,100 & 0,000 & 0,774 \\
\hline Interesse- Rodízio 5 & 0,086 & 0,019 & 0,059 & 0,026 & 0,008 \\
\hline
\end{tabular}




\begin{tabular}{|c|c|c|c|c|c|}
\hline Comunicação - Rodízio 5 & 0,085 & 0,019 & 0,083 & 0,014 & 0,801 \\
\hline Orientação - Rodízio 5 & 0,094 & 0,015 & 0,072 & 0,034 & 0,280 \\
\hline Compromissos - Rodízio 5 & 0,086 & 0,022 & 0,087 & 0,017 & 0,920 \\
\hline Organização - Rodízio 5 & 0,069 & 0,021 & 0,065 & 0,000 & 0,738 \\
\hline Relaciona Mento - Rodízio 5 & 0,089 & 0,022 & 0,096 & 0,009 & 0,538 \\
\hline Atitudinal Nota Final - Rodízio 5 & 0,861 & 0,089 & 0,780 & 0,185 & 0,448 \\
\hline Distribuição - Rodízio 5 & 0,131 & 0,024 & 0,131 & 0,025 & 0,955 \\
\hline Avalia Funcionários- Rodízio 5 & 0,104 & 0,046 & 0,081 & 0,058 & 0,364 \\
\hline Promove Integração - Rodízio 5 & 0,105 & 0,031 & 0,097 & 0,048 & 0,624 \\
\hline Realiza Orientações - Rodízio 5 & 0,102 & 0,033 & 0,076 & 0,037 & 0,144 \\
\hline Escala Mensal - Rodízio 5 & 0,101 & 0,048 & 0,074 & 0,053 & 0,289 \\
\hline Interage com as Equipes - Rodízio 5 & 0,105 & 0,029 & 0,112 & 0,024 & 0,659 \\
\hline Dimensionamento - Rodízio 5 & 0,061 & 0,038 & 0,040 & 0,015 & 0,059 \\
\hline Gestão de Pessoas Nota Final - Rodízio 5 & 0,708 & 0,145 & 0,610 & 0,205 & 0,209 \\
\hline Diagnóstico Médico - Rodízio 5 & 0,267 & 0,083 & 0,257 & 0,088 & 0,819 \\
\hline Processos Fisiopatológicos- Rodízio 5 & 0,275 & 0,083 & 0,224 & 0,040 & 0,232 \\
\hline SAE - Rodízio 5 & 0,286 & 0,075 & 0,277 & 0,066 & 0,813 \\
\hline Evolução De Enfermagem - Rodízio 5 & 0,287 & 0,060 & 0,237 & 0,120 & 0,142 \\
\hline Avalia Anotações - Rodízio 5 & 0,285 & 0,081 & 0,249 & 0,126 & 0,415 \\
\hline Visita Diária - Rodízio 5 & 0,347 & 0,049 & 0,326 & 0,063 & 0,416 \\
\hline Passagem de Plantão - Rodízio 5 & 0,351 & 0,050 & 0,342 & 0,066 & 0,735 \\
\hline Ações de Enfermagem - Rodízio 5 & 0,307 & 0,070 & 0,293 & 0,063 & 0,692 \\
\hline $\begin{array}{l}\text { Gestão de Cuidados Nota Final - Rodízio } \\
5\end{array}$ & 2,406 & 0,372 & 2,204 & 0,531 & 0,317 \\
\hline Taxa de Ocupação - Rodízio 5 & 0,361 & 0,041 & 0,375 & 0,000 & 0,502 \\
\hline Complexidade Do Paciente - Rodízio 5 & 0,330 & 0,069 & 0,310 & 0,076 & 0,579 \\
\hline Profissionais Disponíveis- Rodízio 5 & 0,361 & 0,041 & 0,342 & 0,066 & 0,402 \\
\hline Indicadores - Rodízio 5 & 0,259 & 0,084 & 0,196 & 0,141 & 0,179 \\
\hline Problemas - Rodízio 5 & 0,288 & 0,082 & 0,253 & 0,125 & 0,431 \\
\hline Liderança - Rodízio 5 & 0,247 & 0,079 & 0,204 & 0,081 & 0,298 \\
\hline Serviço de Limpeza - Rodízio 5 & 0,357 & 0,043 & 0,342 & 0,066 & 0,529 \\
\hline Elaboração de Projetos - Rodízio 5 & 0,313 & 0,111 & 0,306 & 0,080 & 0,902 \\
\hline $\begin{array}{l}\text { Gestão Adminstrativa1 Nota Final - } \\
\text { Rodízio } 5\end{array}$ & 2,516 & 0,382 & 2,328 & 0,530 & 0,362 \\
\hline Impressos - Rodízio 5 & 0,232 & 0,032 & 0,207 & 0,050 & 0,147 \\
\hline Relações Intersetoriais - Rodízio 5 & 0,198 & 0,041 & 0,196 & 0,042 & 0,903 \\
\hline Materiais Permanentes - Rodízio 5 & 0,182 & 0,041 & 0,163 & 0,000 & 0,003 \\
\hline Rotinas Diárias - Rodízio 5 & 0,222 & 0,040 & 0,207 & 0,050 & 0,462 \\
\hline $\begin{array}{l}\text { Gestão Administrativa } 2 \text { Nota Final - } \\
\text { Rodízio } 5\end{array}$ & 0,835 & 0,098 & 0,772 & 0,139 & 0,236 \\
\hline Amplia Conhecimento - Rodízio 5 & 0,184 & 0,029 & 0,146 & 0,048 & 0,021 \\
\hline Faz Pesquisa - Rodízio 5 & 0,167 & 0,060 & 0,137 & 0,047 & 0,326 \\
\hline $\begin{array}{l}\text { Explica os Dados Levantados - } \\
\text { Rodízio } 5\end{array}$ & 0,163 & 0,058 & 0,122 & 0,064 & 0,182 \\
\hline Busca Relevante - Rodízio 5 & 0,140 & 0,065 & 0,109 & 0,043 & 0,346 \\
\hline Amplia a Busca - Rodízio 5 & 0,133 & 0,085 & 0,182 & 0,187 & 0,636 \\
\hline $\begin{array}{l}\text { Desenvolvimento Pessoal Nota Final - } \\
\text { Rodízio } 5\end{array}$ & 0,787 & 0,230 & 0,695 & 0,281 & 0,451 \\
\hline Apresentação Pessoal - Rodízio 6 & 0,194 & 0,022 & 0,200 & 0,000 & 0,575 \\
\hline Assiduidade - Rodízio 6 & 0,152 & 0,047 & 0,168 & 0,047 & 0,538 \\
\hline Pontualidade - Rodízio 6 & 0,158 & 0,051 & 0,158 & 0,072 & 0,998 \\
\hline Orientação - Rodízio 6 & 0,188 & 0,030 & 0,200 & 0,000 & 0,441 \\
\hline Material de Uso Pessoal - Rodízio 6 & 0,179 & 0,040 & 0,188 & 0,025 & 0,670 \\
\hline Postura - Rodízio 6 & 0,177 & 0,045 & 0,200 & 0,000 & 0,001 \\
\hline $\begin{array}{l}\text { Construção de Relacionamentos- Rodízio } \\
6\end{array}$ & 0,192 & 0,026 & 0,200 & 0,000 & 0,536 \\
\hline Interesse - Rodízio 6 & 0,182 & 0,033 & 0,143 & 0,051 & 0,035 \\
\hline Organização e Liderança- Rodízio 6 & 0,142 & 0,042 & 0,133 & 0,047 & 0,651 \\
\hline $\begin{array}{l}\text { Responsabilidade e Compromisso - } \\
\text { Rodízio } 6\end{array}$ & 0,183 & 0,034 & 0,175 & 0,050 & 0,667 \\
\hline $\begin{array}{l}\text { Bases Comportamentais Nota Final - } \\
\text { Rodízio } 6\end{array}$ & 1,747 & 0 , & 1,763 & 0,230 & 0,877 \\
\hline Anatomia e Fisiologia- Rodízio 6 & 0,166 & 0,042 & 0,198 & 0,071 & 0,182 \\
\hline
\end{tabular}




\begin{tabular}{|l|l|l|l|l|l|}
\hline Medicamentos - Rodízio 6 & 0,170 & 0,045 & 0,198 & 0,071 & 0,277 \\
\hline Relaciona Exames - Rodízio 6 & 0,173 & 0,046 & 0,215 & 0,077 & 0,102 \\
\hline Dinâmica da Unidade - Rodízio 6 & 0,227 & 0,069 & 0,263 & 0,052 & 0,270 \\
\hline Programas de Saúde - Rodízio 6 & 0,168 & 0,044 & 0,205 & 0,071 & 0,128 \\
\hline Planeja e Organiza- Rodízio 6 & 0,217 & 0,067 & 0,198 & 0,071 & 0,578 \\
\hline Prioridades - Rodízio 6 & 0,230 & 0,071 & 0,195 & 0,054 & 0,300 \\
\hline Indicadores Epidemiológicos - Rodízio 6 & 0,153 & 0,033 & 0,188 & 0,075 & 0,429 \\
\hline Analisa Dados - Rodízio 6 & 0,200 & 0,065 & 0,215 & 0,077 & 0,672 \\
\hline Preenche Relatórios- Rodízio 6 & 0,263 & 0,056 & 0,273 & 0,055 & 0,735 \\
\hline Conhecimentos Científicos Nota Final - & 1,967 & 0,292 & 2,145 & 0,541 & \\
Rodízio 6 & 0,331 & 0,099 & 0,275 & 0,107 & 0,290 \\
\hline Técnicas Básicas - Rodízio 6 & 0,246 & 0,071 & 0,264 & 0,111 & 0,646 \\
\hline Estado Clinico - Rodízio 6 & 0,243 & 0,075 & 0,223 & 0,025 & 0,592 \\
\hline Documenta as Ações - Rodízio 6 & 0,233 & 0,061 & 0,223 & 0,025 & 0,746 \\
\hline Consulta - Rodízio 6 & 0,292 & 0,096 & 0,278 & 0,104 & 0,779 \\
\hline Analisa as Ações - Rodízio 6 & 0,372 & 0,085 & 0,263 & 0,075 & 0,016 \\
\hline Organiza o Trabalho - Rodízio 6 & 0,356 & 0,098 & 0,319 & 0,126 & 0,478 \\
\hline Passagem de Plantão - Rodízio 6 & 2,071 & 0,351 & 1,843 & 0,429 & 0,223 \\
\hline Pratica Assistencial Nota Final - Rodízio 6 & 0,183 & 0,057 & 0,205 & 0,090 & 0,485 \\
\hline Educação Em Saúde - Rodízio 6 & 0,193 & 0,070 & 0,150 & 0,020 & 0,229 \\
\hline Busca Extra Estágio - Rodízio 6 & 0,237 & 0,081 & 0,228 & 0,086 & 0,818 \\
\hline Raciocínio Critico - Rodízio 6 & 0,320 & 0,047 & 0,315 & 0,047 & 0,844 \\
\hline Apresentação do Trabalho - Rodízio 6 & 0,324 & 0,041 & 0,270 & 0,085 & 0,298 \\
\hline Domínio - Rodízio 6 & 0,326 & 0,039 & 0,336 & 0,005 & 0,621 \\
\hline Divisão Das Tarefas - Rodízio 6 & 1,584 & 0,187 & 1,504 & 0,243 & 0,426 \\
\hline Ações Educativas Nota Final - Rodízio 6 & 7,120 & 0,646 & 6,875 & 0,967 & 0,486 \\
\hline Média Final & & & & & \\
\hline
\end{tabular}


APÊNDICE 12 - Comparação do desempenho dos alunos de acordo com a formação na área da enfermagem

\begin{tabular}{|c|c|c|c|}
\hline & $\begin{array}{c}\text { Auxiliar } x \\
\text { técnico }\end{array}$ & $\begin{array}{c}\text { Auxiliar } x \\
\text { outro }\end{array}$ & $\begin{array}{c}\text { Técnico } x \\
\text { outro }\end{array}$ \\
\hline Apresentação Pessoal - Rodízio 1 & 0,604 & 0,287 & 0,697 \\
\hline Assiduidade - Rodízio 1 & 0,780 & 0,934 & 0,906 \\
\hline Pontualidade - Rodízio 1 & 0,914 & 0,958 & 0,620 \\
\hline Postura Ética - Rodízio 1 & 0,849 & 0,957 & 0,499 \\
\hline Interesse - Rodízio 1 & 0,839 & 0,802 & 0,993 \\
\hline Comunicação - Rodízio 1 & 0,961 & 0,169 & 0,015 \\
\hline Orientação - Rodízio 1 & 0,885 & 0,850 & 0,352 \\
\hline Compromisso - Rodízio 1 & 0,488 & 0,567 & 0,988 \\
\hline Uso de Material Pessoal - Rodízio 1 & 0,976 & 0,988 & 0,996 \\
\hline Organização e Liderança - Rodízio 1 & 0,992 & 0,671 & 0,567 \\
\hline Relacionamento - Rodízio 1 & 0,960 & 0,972 & 0,774 \\
\hline Bases Comportamentais Nota Final - Rodízio 1 & 0,668 & 0,355 & 0,730 \\
\hline Anatomia e Fisiologia - Rodízio 1 & 0,472 & 0,957 & 0,455 \\
\hline Fisiopatologia - Rodízio 1 & 0,252 & 0,670 & 0,581 \\
\hline Medicamentos - Rodízio 1 & 0,671 & 0,424 & 0,015 \\
\hline Exames - Rodízio 1 & 0,812 & 0,872 & 0,287 \\
\hline Visitas - Rodízio 1 & 0,163 & 0,575 & 0,502 \\
\hline Conhecimentos Nota Final - Rodízio 1 & 0,339 & 0,998 & 0,166 \\
\hline Reconhece a Clientela- Rodízio 1 & 0,817 & 0,932 & 0,942 \\
\hline Unidade - Rodízio 1 & 0,982 & 0,718 & 0,389 \\
\hline Técnica - Rodízio 1 & 0,200 & 0,245 & 0,000 \\
\hline SAE - Rodízio 1 & 0,846 & 0,623 & 0,114 \\
\hline Documenta - Rodízio 1 & 0,960 & 0,397 & 0,084 \\
\hline Cuidados Especializados - Rodízio 1 & 0,262 & 0,067 & 0,000 \\
\hline Cumpre Prazos - Rodízio 1 & 0,956 & 0,965 & 0,999 \\
\hline Ações de Enfermagem - Rodízio 1 & 0,484 & 0,726 & 0,031 \\
\hline Orientações - Rodízio 1 & 0,859 & 0,828 & 0,288 \\
\hline Efetividade das Ações - Rodízio 1 & 0,028 & 0,439 & 0,148 \\
\hline Passagem de Plantão - Rodízio 1 & 0,342 & 0,960 & 0,066 \\
\hline Pratica Assistencial Nota Final - Rodízio 1 & 0,337 & 0,668 & 0,009 \\
\hline Estudo de Caso - Rodízio 1 & 0,889 & 0,966 & 0,596 \\
\hline Trabalhos - Rodízio 1 & 0,956 & 0,889 & 0,965 \\
\hline Domínio do Conteúdo - Rodízio 1 & 0,629 & 0,974 & 0,611 \\
\hline Reunião - Rodízio 1 & 0,504 & 0,348 & 0,909 \\
\hline Entrega - Rodízio 1 & 1,000 & 0,680 & 0,479 \\
\hline Amplia a Busca - Rodízio 1 & 0,458 & 0,989 & 0,332 \\
\hline Amplia Conhecimento - Rodízio 1 & 0,926 & 0,996 & 0,810 \\
\hline Trabalhos Nota Final - Rodízio 1 & 0,993 & 0,916 & 0,761 \\
\hline Apresentação Pessoal - Rodízio 2 & 0,541 & 0,272 & 0,751 \\
\hline Assiduidade - Rodízio 2 & 0,780 & 0,934 & 0,906 \\
\hline Pontualidade - Rodízio 2 & 0,914 & 0,958 & 0,620 \\
\hline Postura Ética - Rodízio 2 & 0,849 & 0,957 & 0,499 \\
\hline Interesse - Rodízio 2 & 0,839 & 0,802 & 0,993 \\
\hline Comunicação - Rodízio 2 & 0,961 & 0,169 & 0,015 \\
\hline Orientação - Rodízio 2 & 1,000 & 0,680 & 0,479 \\
\hline Compromisso - Rodízio 2 & 1,000 & 1,000 & 1,000 \\
\hline Uso de Material Pessoal - Rodízio 2 & 0,977 & 0,939 & 0,981 \\
\hline Organização e Liderança - Rodízio 2 & 0,139 & 0,840 & 0,164 \\
\hline Relacionamento - Rodízio 2 & 1,000 & 1,000 & 1,000 \\
\hline Bases Comportamentais Nota Final - Rodízio 2 & 0,477 & 0,923 & 0,543 \\
\hline Anatomia e Fisiologia - Rodízio 2 & 0,174 & 0,062 & 0,000 \\
\hline Fisiopatologia - Rodízio 2 & 0,404 & 0,020 & 0,000 \\
\hline Medicamentos - Rodízio 2 & 0,769 & 0,002 & 0,000 \\
\hline Exames - Rodízio 2 & 0,993 & 0,001 & 0,000 \\
\hline Visitas - Rodízio 2 & 0,505 & 0,080 & 0,000 \\
\hline Conhecimentos Nota Final - Rodízio 2 & 0,503 & 0,005 & 0,000 \\
\hline
\end{tabular}




\begin{tabular}{|c|c|c|c|}
\hline Reconhece a Clientela- Rodízio 2 & 0,586 & 0,155 & 0,001 \\
\hline Unidade - Rodízio 2 & 0,574 & 0,991 & 0,460 \\
\hline Técnica - Rodízio 2 & 0,488 & 0,037 & 0,000 \\
\hline SAE - Rodízio 2 & 0,602 & 0,075 & 0,000 \\
\hline Documenta - Rodízio 2 & 0,550 & 0,085 & 0,000 \\
\hline Cuidados Especializados - Rodízio 2 & 0,554 & 0,020 & 0,000 \\
\hline Cumpre Prazos - Rodízio 2 & 0,684 & 0,068 & 0,000 \\
\hline Ações de Enfermagem - Rodízio 2 & 0,513 & 0,153 & 0,000 \\
\hline Orientações - Rodízio 2 & 0,780 & 0,060 & 0,000 \\
\hline Efetividade das Ações - Rodízio 2 & 0,507 & 0,146 & 0,000 \\
\hline Passagem de Plantão - Rodízio 2 & 0,682 & 0,337 & 0,009 \\
\hline Pratica Assistencial Nota Final - Rodízio 2 & 0,336 & 0,019 & 0,000 \\
\hline Estudo de Caso - Rodízio 2 & 0,996 & 0,994 & 0,963 \\
\hline Trabalhos - Rodízio 2 & 0,788 & 0,267 & 0,409 \\
\hline Domínio do Conteúdo - Rodízio 2 & 0,768 & 0,832 & 0,200 \\
\hline Reunião - Rodízio 2 & 0,038 & 0,179 & 0,612 \\
\hline Entrega - Rodízio 2 & 0,939 & 0,993 & 0,813 \\
\hline Amplia a Busca - Rodízio 2 & 0,403 & 0,800 & 0,656 \\
\hline Amplia Conhecimento - Rodízio 2 & 0,100 & 0,396 & 0,553 \\
\hline Trabalhos Nota Final - Rodízio 2 & 0,289 & 0,907 & 0,306 \\
\hline Apresentação Pessoal - Rodízio 3 & 0,380 & 0,986 & 0,254 \\
\hline Assiduidade - Rodízio 3 & 0,729 & 0,566 & 0,057 \\
\hline Pontualidade - Rodízio 3 & 0,967 & 0,716 & 0,735 \\
\hline Postura Ética - Rodízio 3 & 0,647 & 0,913 & 0,792 \\
\hline Interesse - Rodízio 3 & 0,508 & 0,994 & 0,363 \\
\hline Comunicação - Rodízio 3 & 0,751 & 0,990 & 0,707 \\
\hline Orientação - Rodízio 3 & 0,181 & 0,831 & 0,238 \\
\hline Compromisso - Rodízio 3 & 0,982 & 0,692 & 0,358 \\
\hline Uso de Material Pessoal - Rodízio 3 & 0,912 & 0,372 & 0,388 \\
\hline Organização e Liderança - Rodízio 3 & 0,890 & 0,872 & 0,393 \\
\hline Relacionamento - Rodízio 3 & 0,159 & 0,427 & 0,704 \\
\hline Bases Comportamentais Nota Final - Rodízio 3 & 0,474 & 0,929 & 0,101 \\
\hline Anatomia e Fisiologia - Rodízio 3 & 0,232 & 0,334 & 0,960 \\
\hline Fisiopatologia - Rodízio 3 & 0,902 & 0,224 & 0,015 \\
\hline Medicamentos - Rodízio 3 & 0,997 & 0,289 & 0,119 \\
\hline Exames - Rodízio 3 & 0,625 & 0,945 & 0,215 \\
\hline Visitas - Rodízio 3 & 0,949 & 0,818 & 0,427 \\
\hline Conhecimentos Nota Final - Rodízio 3 & 0,691 & 0,680 & 0,069 \\
\hline Reconhece a Clientela- Rodízio 3 & 0,363 & 0,902 & 0,420 \\
\hline Unidade - Rodízio 3 & 0,481 & 0,360 & 0,941 \\
\hline Técnica - Rodízio 3 & 0,277 & 0,999 & 0,112 \\
\hline SAE - Rodízio 3 & 0,445 & 0,780 & 0,746 \\
\hline Documenta - Rodízio 3 & 0,026 & 0,484 & 0,111 \\
\hline Cuidados Especializados - Rodízio 3 & 0,249 & 0,258 & 1,000 \\
\hline Cumpre Prazos - Rodízio 3 & 0,291 & 0,913 & 0,300 \\
\hline Ações de Enfermagem - Rodízio 3 & 0,013 & 0,211 & 0,233 \\
\hline Orientações - Rodízio 3 & 0,485 & 0,529 & 0,997 \\
\hline Efetividade das Ações - Rodízio 3 & 0,926 & 0,949 & 0,996 \\
\hline Passagem de Plantão - Rodízio 3 & 0,631 & 0,994 & 0,351 \\
\hline Pratica assistencial nota final - Rodízio 3 & 0,568 & 0,986 & 0,481 \\
\hline Estudo de caso - Rodízio 3 & 0,948 & 0,790 & 0,878 \\
\hline Trabalhos - Rodízio 3 & 0,256 & 0,259 & 0,999 \\
\hline Domínio do conteúdo - Rodízio 3 & 0,105 & 0,886 & 0,003 \\
\hline Reunião - Rodízio 3 & 0,980 & 0,709 & 0,680 \\
\hline Entrega - Rodízio 3 & 0,967 & 0,543 & 0,497 \\
\hline Amplia a Busca - Rodízio 3 & 0,143 & 0,262 & 0,909 \\
\hline Amplia Conhecimento - Rodízio 3 & 0,039 & 0,135 & 0,748 \\
\hline Trabalhos Nota Final - Rodízio 3 & 0,259 & 0,557 & 0,750 \\
\hline Apresentação Pessoal - Rodízio 4 & 1,000 & 1,000 & 1,000 \\
\hline Assiduidade - Rodízio 4 & 0,903 & 0,226 & 0,203 \\
\hline Pontualidade - Rodízio 4 & 0,597 & 0,609 & 1,000 \\
\hline Orientação - Rodízio 4 & 0,797 & 0,804 & 0,200 \\
\hline Material de Uso Pessoal - Rodízio 4 & 0,134 & 0,163 & 0,996 \\
\hline
\end{tabular}




\begin{tabular}{|c|c|c|c|}
\hline Postura - Rodízio 4 & 0,897 & 0,901 & 1,000 \\
\hline Construção de Relacionamentos - Rodízio 4 & 0,959 & 0,953 & 0,999 \\
\hline Interesse - Rodízio 4 & 0,285 & 0,038 & 0,327 \\
\hline Organização e Liderança - Rodízio 4 & 0,797 & 0,804 & 0,200 \\
\hline Responsabilidade e Compromisso - Rodízio 4 & 0,847 & 0,895 & 0,991 \\
\hline Bases Comportamentais Nota Final - Rodízio 4 & 0,999 & 0,737 & 0,523 \\
\hline Anatomia e Fisiologia - Rodízio 4 & 0,058 & 0,496 & 0,245 \\
\hline Medicamentos - Rodízio 4 & 0,533 & 0,295 & 0,003 \\
\hline Relaciona Exames - Rodízio 4 & 0,791 & 0,972 & 0,459 \\
\hline Dinâmica da Unidade - Rodízio 4 & 0,776 & 0,995 & 0,711 \\
\hline Programas de Saúde - Rodízio 4 & 1,000 & 1,000 & 1,000 \\
\hline Planeja e Organiza - Rodízio 4 & 0,926 & 1,000 & 0,852 \\
\hline Prioridades - Rodízio 4 & 0,529 & 0,503 & 0,996 \\
\hline Indicadores Epidemiológicos - Rodízio 4 & 1,000 & 1,000 & 1,000 \\
\hline Analisa dados - Rodízio 4 & 0,863 & 0,953 & 0,954 \\
\hline Preenche Relatórios - Rodízio 4 & 0,929 & 0,189 & 0,132 \\
\hline Conhecimentos Científicos Nota Final - Rodízio 4 & 0,368 & 0,965 & 0,081 \\
\hline Técnicas Básicas - Rodízio 4 & 0,957 & 0,601 & 0,208 \\
\hline Estado Clinico - Rodízio 4 & 0,544 & 0,994 & 0,266 \\
\hline Documenta as Ações - Rodízio 4 & 0,427 & 0,010 & 0,038 \\
\hline Consulta - Rodízio 4 & 0,395 & 0,996 & 0,149 \\
\hline Analisa as Ações - Rodízio 4 & 0,833 & 0,966 & 0,501 \\
\hline Organiza o Trabalho - Rodízio 4 & 0,225 & 0,545 & 0,001 \\
\hline Passagem de Plantão - Rodízio 4 & 0,759 & 0,489 & 0,037 \\
\hline Pratica Assistencial Nota Final - Rodízio 4 & 0,508 & 0,182 & 0,001 \\
\hline Educação em Saúde - Rodízio 4 & 0,952 & 0,390 & 0,335 \\
\hline Busca Extra Estágio - Rodízio 4 & 0,973 & 0,637 & 0,606 \\
\hline Raciocínio Critico - Rodízio 4 & 0,634 & 0,359 & 0,780 \\
\hline Apresentação do Trabalho - Rodízio 4 & 0,972 & 0,726 & 0,733 \\
\hline Domínio - Rodízio 4 & 0,996 & 0,961 & 0,964 \\
\hline Divisão das Tarefas - Rodízio 4 & 0,698 & 0,309 & 0,611 \\
\hline Ações Educativas Nota Final - Rodízio 4 & 0,872 & 0,604 & 0,790 \\
\hline Apresentação Pessoal - Rodízio 5 & 1,000 & 0,570 & 0,344 \\
\hline Assiduidade - Rodízio 5 & 0,890 & 0,885 & 0,414 \\
\hline Pontualidade - Rodízio 5 & 0,892 & 0,988 & 0,911 \\
\hline Postura Ética - Rodízio 5 & 1,000 & 0,680 & 0,479 \\
\hline Interesse - Rodízio 5 & 0,992 & 0,909 & 0,741 \\
\hline Comunicação - Rodízio 5 & 0,563 & 1,000 & 0,351 \\
\hline Orientação - Rodízio 5 & 0,817 & 0,923 & 0,375 \\
\hline Compromissos - Rodízio 5 & 0,944 & 0,425 & 0,399 \\
\hline Organização - Rodízio 5 & 0,790 & 0,526 & 0,053 \\
\hline Relacionamento - Rodízio 5 & 0,622 & 0,619 & 0,999 \\
\hline Atitudinal Nota Final - Rodízio 5 & 0,985 & 0,481 & 0,169 \\
\hline Distribuição - Rodízio 5 & 0,969 & 0,267 & 0,162 \\
\hline Avalia Funcionários - Rodízio 5 & 0,997 & 0,682 & 0,426 \\
\hline Promove Integração - Rodízio 5 & 0,712 & 0,129 & 0,001 \\
\hline Realiza Orientações - Rodízio 5 & 1,000 & 0,223 & 0,058 \\
\hline Escala Mensal - Rodízio 5 & 0,576 & 0,944 & 0,175 \\
\hline Interage com as Equipes - Rodízio 5 & 0,964 & 0,534 & 0,168 \\
\hline Dimensionamento - Rodízio 5 & 0,493 & 0,645 & 0,949 \\
\hline Gestão de Pessoas Nota Final - Rodízio 5 & 0,893 & 0,236 & 0,228 \\
\hline Diagnóstico Médico - Rodízio 5 & 0,777 & 0,732 & 0,132 \\
\hline Processos Fisiopatológicos - Rodízio 5 & 0,351 & 0,999 & 0,138 \\
\hline SAE - Rodízio 5 & 0,215 & 0,477 & 0,769 \\
\hline Evolução de Enfermagem -Rodízio 5 & 0,125 & 0,529 & 0,453 \\
\hline Avalia Anotações - Rodízio 5 & 0,816 & 0,857 & 0,274 \\
\hline Visita Diária - Rodízio 5 & 1,000 & 0,568 & 0,341 \\
\hline Passagem de Plantão - Rodízio 5 & 0,759 & 0,927 & 0,311 \\
\hline Ações de Enfermagem - Rodízio 5 & 0,491 & 0,996 & 0,327 \\
\hline Gestão de Cuidados Nota Final - Rodízio 5 & 0,280 & 1,000 & 0,096 \\
\hline Taxa de Ocupação - Rodízio 5 & 0,732 & 0,666 & 0,984 \\
\hline Complexidade do Paciente - Rodízio 5 & 0,673 & 0,775 & 0,101 \\
\hline Profissionais Disponíveis - Rodízio 5 & 0,933 & 0,247 & 0,192 \\
\hline
\end{tabular}




\begin{tabular}{|c|c|c|c|}
\hline Indicadores - Rodízio 5 & 0,270 & 0,515 & 0,002 \\
\hline Problemas - Rodízio 5 & 0,367 & 0,757 & 0,018 \\
\hline Liderança - Rodízio 5 & 0,940 & 0,276 & 0,032 \\
\hline Serviço de Limpeza - Rodízio 5 & 0,862 & 0,129 & 0,114 \\
\hline Elaboração de Projetos - Rodízio 5 & 0,838 & 0,984 & 0,573 \\
\hline Gestão Administrativa 1 Nota Final - Rodízio 5 & 0,680 & 0,370 & 0,011 \\
\hline Impressos - Rodízio 5 & 0,990 & 0,189 & 0,029 \\
\hline Relações Intersetoriais - Rodízio 5 & 0,534 & 0,999 & 0,299 \\
\hline Materiais Permanentes - Rodízio 5 & 0,530 & 0,102 & 0,329 \\
\hline Rotinas Diárias - Rodízio 5 & 0,619 & 0,981 & 0,572 \\
\hline Gestão Administrativa 2 Nota Final - Rodízio 5 & 0,879 & 0,346 & 0,033 \\
\hline Amplia Conhecimento - Rodízio 5 & 0,151 & 0,721 & 0,297 \\
\hline Faz Pesquisa - Rodízio 5 & 0,863 & 0,165 & 0,161 \\
\hline Explica os Dados Levantados - Rodízio 5 & 0,452 & 0,217 & 0,759 \\
\hline Busca Relevante - Rodízio 5 & 0,603 & 0,034 & 0,069 \\
\hline Amplia a Busca - Rodízio 5 & 0,739 & 0,999 & 0,532 \\
\hline Desenvolvimento Pessoal Nota Final - Rodízio 5 & 0,776 & 0,205 & 0,312 \\
\hline Apresentação Pessoal - Rodízio 6 & 0,610 & 0,671 & 0,994 \\
\hline Assiduidade - Rodízio 6 & 0,999 & 0,985 & 0,985 \\
\hline Pontualidade - Rodízio 6 & 0,997 & 0,823 & 0,748 \\
\hline Orientação - Rodízio 6 & 0,041 & 0,087 & 0,918 \\
\hline Material de Uso Pessoal - Rodízio 6 & 0,510 & 0,623 & 0,973 \\
\hline Postura - Rodízio 6 & 0,989 & 0,787 & 0,752 \\
\hline Construção de Relacionamentos - Rodízio 6 & 0,672 & 0,810 & 0,952 \\
\hline Interesse - Rodízio 6 & 0,127 & 0,251 & 0,889 \\
\hline Organização e Liderança - Rodízio 6 & 0,854 & 0,988 & 0,859 \\
\hline Responsabilidade e Compromisso - Rodízio 6 & 0,375 & 0,517 & 0,950 \\
\hline Bases Comportamentais Nota Final - Rodízio 6 & 0,279 & 0,457 & 0,902 \\
\hline Anatomia e Fisiologia - Rodízio 6 & 0,238 & 0,941 & 0,027 \\
\hline Medicamentos - Rodízio 6 & 0,896 & 0,456 & 0,070 \\
\hline Relaciona Exames - Rodízio 6 & 0,910 & 0,797 & 0,323 \\
\hline Dinâmica da Unidade - Rodízio 6 & 0,482 & 0,811 & 0,753 \\
\hline Programas de Saúde - Rodízio 6 & 0,809 & 0,830 & 0,999 \\
\hline Planeja e Organiza - Rodízio 6 & 0,228 & 0,253 & 0,999 \\
\hline Prioridades - Rodízio 6 & 0,854 & 0,531 & 0,722 \\
\hline Indicadores Epidemiológicos - Rodízio 6 & 0,591 & 0,917 & 0,154 \\
\hline Analisa Dados - Rodízio 6 & 0,397 & 0,469 & 0,989 \\
\hline Preenche Relatórios - Rodízio 6 & 0,120 & 0,125 & 1,000 \\
\hline Conhecimentos Científicos Nota Final - Rodízio 6 & 0,144 & 0,562 & 0,468 \\
\hline Técnicas Básicas - Rodízio 6 & 0,550 & 0,982 & 0,474 \\
\hline Estado Clinico - Rodízio 6 & 0,784 & 0,252 & 0,388 \\
\hline Documenta as Ações - Rodízio 6 & 0,974 & 0,763 & 0,420 \\
\hline Consulta - Rodízio 6 & 0,755 & 0,995 & 0,515 \\
\hline Analisa as Ações - Rodízio 6 & 0,303 & 0,995 & 0,149 \\
\hline Organiza o Trabalho - Rodízio 6 & 0,409 & 0,679 & 0,830 \\
\hline Passagem De Plantão - Rodízio 6 & 0,812 & 0,542 & 0,065 \\
\hline Pratica Assistencial Nota Final - Rodízio 6 & 0,438 & 0,867 & 0,055 \\
\hline Educação em Saúde - Rodízio 6 & 0,638 & 0,833 & 0,902 \\
\hline Busca Extra Estágio - Rodízio 6 & 0,893 & 0,741 & 0,239 \\
\hline Raciocínio Critico - Rodízio 6 & 0,956 & 0,720 & 0,318 \\
\hline Apresentação do Trabalho - Rodízio 6 & 0,934 & 0,597 & 0,660 \\
\hline Domínio - Rodízio 6 & 0,698 & 0,985 & 0,384 \\
\hline Divisão das Tarefas - Rodízio 6 & 0,552 & 0,523 & 0,995 \\
\hline Ações Educativas Nota Final - Rodízio 6 & 0,517 & 1,000 & 0,304 \\
\hline Média Final & 0,131 & 0,672 & 0,001 \\
\hline
\end{tabular}




\section{APÊNDICE 13 - Comparação do desempenho dos estudantes de} acordo com o turno de trabalho.

\begin{tabular}{|c|c|c|c|}
\hline & $\begin{array}{c}\text { Não } \\
\text { trabalha } x \\
\text { tarde }\end{array}$ & $\begin{array}{c}\text { Não } \\
\text { trabalha x } \\
\text { noite }\end{array}$ & $\begin{array}{l}\text { Tarde } x \\
\text { noite }\end{array}$ \\
\hline Apresentação Pessoal - Rodízio1 & 0,997 & 0,847 & 0,828 \\
\hline Assiduidade - Rodízio1 & 0,909 & 0,990 & 0,800 \\
\hline Pontualidade - Rodízio1 & 0,999 & 0,730 & 0,663 \\
\hline Postura Ética - Rodízio 1 & 0,287 & 0,241 & 0,969 \\
\hline Interesse - Rodízio 1 & 1,000 & 0,785 & 0,708 \\
\hline Comunicação - Rodízio 1 & 0,452 & 0,808 & 0,095 \\
\hline Orientação - Rodízio 1 & 0,876 & 0,726 & 0,310 \\
\hline Compromisso - Rodízio 1 & 0,784 & 0,855 & 0,348 \\
\hline Uso de Material Pessoal - Rodízio 1 & 0,964 & 0,495 & 0,229 \\
\hline Organização e Liderança - Rodízio 1 & 0,625 & 0,924 & 0,822 \\
\hline Relacionamento - Rodízio 1 & 0,968 & 0,715 & 0,783 \\
\hline $\begin{array}{l}\text { Bases Comportamentais Nota Final - } \\
\text { Rodízio } 1\end{array}$ & 0,994 & 0,773 & 0,758 \\
\hline Anatomia e Fisiologia - Rodízio 1 & 0,921 & 0,402 & 0,122 \\
\hline Fisiopatologia - Rodízio 1 & 0,999 & 0,433 & 0,321 \\
\hline Medicamentos - Rodízio 1 & 1,000 & 0,025 & 0,006 \\
\hline Exames - Rodízio 1 & 0,860 & 0,131 & 0,186 \\
\hline Visitas - Rodízio 1 & 0,579 & 0,509 & 0,976 \\
\hline Conhecimentos Nota Final - Rodízio 1 & 0,956 & 0,131 & 0,111 \\
\hline Reconhece a Clientela - Rodízio 1 & 0,999 & 0,174 & 0,092 \\
\hline Unidade - Rodízio 1 & 0,993 & 0,090 & 0,024 \\
\hline Técnica - Rodízio 1 & 0,590 & 0,004 & 0,013 \\
\hline SAE - Rodízio 1 & 0,873 & 0,011 & 0,009 \\
\hline Documenta - Rodízio 1 & 0,976 & 0,020 & 0,002 \\
\hline Cuidados Especializados - Rodízio 1 & 0,754 & 0,009 & 0,000 \\
\hline Cumpre Prazos - Rodízio 1 & 0,986 & 0,412 & 0,366 \\
\hline Ações de Enfermagem - Rodízio 1 & 0,703 & 0,186 & 0,010 \\
\hline Orientações - Rodízio 1 & 0,505 & 1,000 & 0,420 \\
\hline Efetividade das Ações - Rodízio 1 & 0,627 & 0,701 & 0,118 \\
\hline Passagem de Plantão - Rodízio 1 & 0,207 & 0,073 & 0,728 \\
\hline Pratica Assistencial Nota Final - Rodízio1 & 0,998 & 0,008 & 0,001 \\
\hline Estudo de Caso - Rodízio 1 & 0,996 & 0,953 & 0,894 \\
\hline Trabalhos - Rodízio 1 & 0,758 & 0,751 & 0,223 \\
\hline Domínio do Conteúdo - Rodízio 1 & 0,951 & 0,287 & 0,084 \\
\hline Reunião - Rodízio 1 & 0,931 & 0,589 & 0,716 \\
\hline Entrega - Rodízio 1 & 0,182 & 0,219 & 1,000 \\
\hline Amplia a Busca - Rodízio 1 & 0,958 & 0,970 & 0,819 \\
\hline Amplia Conhecimento - Rodízio 1 & 0,986 & 0,667 & 0,448 \\
\hline Trabalhos Nota Final - Rodízio 1 & 0,986 & 0,410 & 0,202 \\
\hline Apresentação Pessoal - - Rodízio 2 & 0,825 & 0,717 & 0,961 \\
\hline Assiduidade - Rodízio 2 & 0,909 & 0,990 & 0,800 \\
\hline Pontualidade - Rodízio 2 & 0,999 & 0,730 & 0,663 \\
\hline Postura Ética - Rodízio 2 & 0,287 & 0,241 & 0,969 \\
\hline Interesse - Rodízio 2 & 1,000 & 0,785 & 0,708 \\
\hline Comunicação - Rodízio 2 & 0,452 & 0,808 & 0,095 \\
\hline Orientação - Rodízio 2 & 0,685 & 1,000 & 0,614 \\
\hline Compromisso - Rodízio 2 & 1,000 & 1,000 & 1,000 \\
\hline Uso De Material Pessoal - Rodízio 2 & 0,845 & 0,308 & 0,481 \\
\hline Organização E Liderança - Rodízio 2 & 0,949 & 0,218 & 0,216 \\
\hline Relacionamento - Rodízio 2 & 1,000 & 1,000 & 1,000 \\
\hline $\begin{array}{l}\text { Bases Comportamentais Nota Final - } \\
\text { Rodízio } 2\end{array}$ & 0,957 & 0,539 & 0,253 \\
\hline
\end{tabular}




\begin{tabular}{|c|c|c|c|}
\hline Anatomia E Fisiologia - Rodízio 2 & 0,765 & 0,059 & 0,002 \\
\hline Fisiopatologia - Rodízio 2 & 0,571 & 0,028 & 0,000 \\
\hline Medicamentos - Rodízio 2 & 0,948 & 0,000 & 0,000 \\
\hline Exames - Rodízio 2 & 0,945 & 0,001 & 0,000 \\
\hline Visitas - Rodízio 2 & 0,942 & 0,006 & 0,002 \\
\hline Conhecimentos Nota Final - Rodízio 2 & 0,949 & 0,003 & 0,000 \\
\hline Reconhece a Clientela - Rodízio 2 & 0,583 & 0,033 & 0,123 \\
\hline Unidade - Rodízio 2 & 0,959 & 0,111 & 0,088 \\
\hline Técnica - Rodízio 2 & 0,981 & 0,030 & 0,013 \\
\hline SAE - Rodízio 2 & 0,481 & 0,044 & 0,000 \\
\hline Documenta - Rodízio 2 & 0,957 & 0,009 & 0,003 \\
\hline Cuidados Especializados - Rodízio 2 & 0,938 & 0,027 & 0,018 \\
\hline Cumpre Prazos - Rodízio 2 & 0,957 & 0,059 & 0,040 \\
\hline Ações de Enfermagem - Rodízio 2 & 0,239 & 0,063 & 0,000 \\
\hline Orientações - Rodízio 2 & 0,976 & 0,056 & 0,009 \\
\hline Efetividade das Ações - Rodízio 2 & 0,965 & 0,007 & 0,003 \\
\hline Passagem de Plantão - Rodízio 2 & 0,752 & 0,014 & 0,023 \\
\hline Pratica Assistencial Nota Final - Rodízio2 & 0,997 & 0,002 & 0,000 \\
\hline Estudo de Caso- Rodízio 2 & 0,674 & 0,880 & 0,279 \\
\hline Trabalhos - Rodízio 2 & 0,864 & 0,037 & 0,043 \\
\hline Domínio do Conteúdo - Rodízio 2 & 0,858 & 0,981 & 0,690 \\
\hline Reunião - Rodízio 2 & 0,413 & 0,792 & 0,783 \\
\hline Entrega - Rodízio 2 & 0,155 & 0,887 & 0,265 \\
\hline Amplia a Busca - Rodízio 2 & 0,906 & 0,496 & 0,649 \\
\hline Amplia Conhecimento - Rodízio 2 & 0,994 & 0,689 & 0,656 \\
\hline Trabalhos Nota Final - Rodízio 2 & 0,780 & 0,538 & 0,111 \\
\hline Apresentação Pessoal - Rodízio 3 & 0,985 & 0,297 & 0,121 \\
\hline Assiduidade - Rodízio 3 & 0,245 & 0,741 & 0,024 \\
\hline Pontualidade - Rodízio 3 & 0,957 & 0,806 & 0,901 \\
\hline Postura Ética - Rodízio 3 & 0,859 & 0,978 & 0,679 \\
\hline Interesse - Rodízio 3 & 0,853 & 0,227 & 0,345 \\
\hline Comunicação - Rodízio 3 & 0,643 & 0,458 & 0,904 \\
\hline Orientação - Rodízio 3 & 0,996 & 0,396 & 0,309 \\
\hline Compromisso - Rodízio 3 & 0,977 & 0,608 & 0,356 \\
\hline Uso de Material Pessoal - Rodízio 3 & 0,971 & 0,644 & 0,692 \\
\hline Organização e Liderança - Rodízio 3 & 0,960 & 0,355 & 0,127 \\
\hline Relacionamento- Rodízio 3 & 0,399 & 0,922 & 0,137 \\
\hline $\begin{array}{l}\text { Bases Comportamentais Nota Final - } \\
\text { Rodízio } 3\end{array}$ & 0,936 & 0,338 & 0,099 \\
\hline Anatomia e Fisiologia - Rodízio 3 & 0,348 & 0,981 & 0,365 \\
\hline Fisiopatologia - Rodízio 3 & 0,949 & 0,638 & 0,326 \\
\hline Medicamentos - Rodízio 3 & 0,994 & 0,884 & 0,769 \\
\hline Exames - Rodízio 3 & 0,991 & 0,841 & 0,693 \\
\hline Visitas - Rodízio 3 & 0,905 & 0,791 & 0,416 \\
\hline Conhecimentos Nota Final - Rodízio 3 & 0,841 & 0,765 & 0,308 \\
\hline Reconhece a Clientela - Rodízio 3 & 0,257 & 0,998 & 0,199 \\
\hline Unidade - Rodízio 3 & 0,378 & 0,420 & 1,000 \\
\hline Técnica - Rodízio 3 & 0,874 & 0,239 & 0,340 \\
\hline SAE - Rodízio 3 & 0,855 & 0,770 & 0,972 \\
\hline Documenta - Rodízio 3 & 0,462 & 0,199 & 0,734 \\
\hline Cuidados Especializados - Rodízio 3 & 0,351 & 0,712 & 0,801 \\
\hline Cumpre Prazos - Rodízio 3 & 0,862 & 0,176 & 0,255 \\
\hline Ações de Enfermagem - Rodízio 3 & 0,943 & 0,889 & 0,623 \\
\hline Orientações - Rodízio 3 & 0,415 & 0,852 & 0,706 \\
\hline Efetividade das Ações - Rodízio 3 & 0,978 & 0,840 & 0,893 \\
\hline Passagem de Plantão - Rodízio 3 & 0,956 & 0,158 & 0,034 \\
\hline $\begin{array}{l}\text { Pratica Assistencial Nota Final - Rodízio } \\
3\end{array}$ & 0,119 & 0,090 & 0,950 \\
\hline Estudo de Caso- Rodízio 3 & 0,353 & 0,910 & 0,529 \\
\hline Trabalhos - Rodízio 3 & 0,673 & 0,914 & 0,882 \\
\hline Domínio do Conteúdo - Rodízio 3 & 0,466 & 0,173 & 0,003 \\
\hline Reunião - Rodízio 3 & 0,442 & 0,149 & 0,641 \\
\hline Entrega - Rodízio 3 & 1,000 & 0,919 & 0,888 \\
\hline
\end{tabular}




\begin{tabular}{|c|c|c|c|}
\hline Amplia a Busca - Rodízio 3 & 0,981 & 0,944 & 0,819 \\
\hline Amplia Conhecimento - Rodízio 3 & 0,601 & 0,542 & 0,981 \\
\hline Trabalhos Nota Final - Rodízio 3 & 0,970 & 0,958 & 0,997 \\
\hline Apresentação Pessoal - Rodízio 4 & 1,000 & 1,000 & 1,000 \\
\hline Assiduidade - Rodízio 4 & 0,935 & 0,677 & 0,341 \\
\hline Pontualidade - Rodízio 4 & 0,918 & 0,497 & 0,628 \\
\hline Orientação - Rodízio 4 & 0,966 & 0,130 & 0,101 \\
\hline Material de Uso Pessoal - Rodízio 4 & 0,885 & 0,957 & 0,657 \\
\hline Postura - Rodízio 4 & 0,988 & 0,787 & 0,599 \\
\hline $\begin{array}{l}\text { Construção de Relacionamentos- } \\
\text { Rodízio } 4\end{array}$ & 0,976 & 0,916 & 0,751 \\
\hline Interesse - Rodízio 4 & 0,863 & 0,969 & 0,658 \\
\hline Organização e Liderança - Rodízio 4 & 0,878 & 0,255 & 0,358 \\
\hline $\begin{array}{l}\text { Responsabilidade e Compromisso - } \\
\text { Rodízio } 4\end{array}$ & 0,449 & 0,619 & 0,966 \\
\hline $\begin{array}{l}\text { Bases Comportamentais Nota Final } \\
\text { Rodízio } 4\end{array}$ & 0,997 & 0,977 & 0,985 \\
\hline Anatomia e Fisiologia - Rodízio 4 & 0,898 & 1,000 & 0,856 \\
\hline Medicamentos - Rodízio 4 & 0,983 & 0,214 & 0,162 \\
\hline Relaciona Exames - Rodízio 4 & 0,999 & 0,925 & 0,872 \\
\hline Dinâmica da Unidade - Rodízio 4 & 0,989 & 0,988 & 0,938 \\
\hline Programas de Saúde - Rodízio 4 & 1,000 & 1,000 & 1,000 \\
\hline Planeja e Organiza - Rodízio 4 & 0,965 & 0,841 & 0,921 \\
\hline Prioridades - Rodízio 4 & 0,060 & 0,129 & 0,959 \\
\hline Indicadores Epidemiológicos- Rodízio 4 & 1,000 & 1,000 & 1,000 \\
\hline Analisa Dados - Rodízio 4 & 0,947 & 0,549 & 0,245 \\
\hline Preenche Relatórios - Rodízio 4 & 0,835 & 0,350 & 0,557 \\
\hline $\begin{array}{l}\text { Conhecimentos Científicos Nota Final - } \\
\text { Rodízio } 4\end{array}$ & 0,996 & 0,933 & 0,860 \\
\hline Técnicas Básicas - Rodízio 4 & 0,997 & 0,650 & 0,485 \\
\hline Estado Clinico - Rodízio 4 & 0,897 & 0,916 & 1,000 \\
\hline Documenta as Ações - Rodízio 4 & 0,780 & 0,074 & 0,003 \\
\hline Consulta - Rodízio 4 & 0,766 & 0,388 & 0,054 \\
\hline Analisa as Ações - Rodízio 4 & 0,987 & 0,911 & 0,945 \\
\hline Organiza o Trabalho - Rodízio 4 & 0,803 & 0,488 & 0,781 \\
\hline Passagem de Plantão - Rodízio 4 & 0,765 & 0,198 & 0,391 \\
\hline $\begin{array}{l}\text { Pratica Assistencial Nota Final - Rodízio } \\
4\end{array}$ & 0,971 & 0,203 & 0,171 \\
\hline Educação em Saúde - Rodízio 4 & 0,982 & 0,969 & 0,996 \\
\hline Busca Extra Estágio - Rodízio 4 & 0,650 & 0,999 & 0,539 \\
\hline Raciocínio Critico - Rodízio 4 & 1,000 & 0,985 & 0,972 \\
\hline Apresentação do Trabalho- Rodízio 4 & 0,739 & 0,958 & 0,869 \\
\hline Domínio - Rodízio 4 & 0,589 & 0,986 & 0,393 \\
\hline Divisão das Tarefas - Rodízio 4 & 0,996 & 0,884 & 0,883 \\
\hline Ações Educativas Nota Final - Rodízio 4 & 0,953 & 0,993 & 0,887 \\
\hline Apresentação Pessoal - Rodízio 5 & 0,577 & 1,000 & 0,493 \\
\hline Assiduidade- Rodízio 5 & 0,784 & 0,887 & 0,980 \\
\hline Pontualidade- Rodízio 5 & 0,633 & 0,115 & 0,339 \\
\hline Postura Ética - Rodízio 5 & 0,685 & 1,000 & 0,614 \\
\hline Interesse- Rodízio 5 & 0,926 & 0,972 & 0,987 \\
\hline Comunicação - Rodízio 5 & 0,922 & 0,572 & 0,713 \\
\hline Orientação - Rodízio 5 & 0,493 & 1,000 & 0,404 \\
\hline Compromissos - Rodízio 5 & 0,869 & 0,939 & 0,985 \\
\hline Organização- Rodízio 5 & 0,960 & 0,721 & 0,434 \\
\hline Relacionamento- Rodízio 5 & 0,358 & 0,481 & 0,985 \\
\hline Atitudinal Nota Final- Rodízio 5 & 0,457 & 0,766 & 0,859 \\
\hline Distribuição - Rodízio 5 & 0,792 & 0,255 & 0,462 \\
\hline Avalia Funcionários- Rodízio 5 & 0,647 & 0,974 & 0,413 \\
\hline Promove Integração - Rodízio 5 & 0,974 & 0,946 & 0,802 \\
\hline Realiza Orientações - Rodízio 5 & 0,647 & 0,766 & 0,163 \\
\hline Escala Mensal - Rodízio 5 & 0,935 & 0,996 & 0,952 \\
\hline Interage com as Equipes - Rodízio 5 & 0,882 & 0,308 & 0,430 \\
\hline Dimensionamento - Rodízio 5 & 0,974 & 0,901 & 0,722 \\
\hline
\end{tabular}




\begin{tabular}{|c|c|c|c|}
\hline $\begin{array}{l}\text { Gestão de Pessoas Nota Final - Rodízio } \\
5\end{array}$ & 0,958 & 0,579 & 0,287 \\
\hline Diagnóstico Médico - Rodízio 5 & 0,999 & 0,977 & 0,979 \\
\hline Processos Fisiopatológicos- Rodízio 5 & 1,000 & 0,948 & 0,925 \\
\hline SAE - Rodízio 5 & 0,782 & 0,973 & 0,875 \\
\hline Evolução de Enfermagem - Rodízio 5 & 0,963 & 0,604 & 0,664 \\
\hline Avalia Anotações-Rodízio 5 & 0,512 & 0,938 & 0,227 \\
\hline Visita Diária - Rodízio 5 & 0,965 & 0,843 & 0,922 \\
\hline Passagem de Plantão - Rodízio 5 & 0,526 & 0,976 & 0,592 \\
\hline Ações de Enfermagem - Rodízio 5 & 0,785 & 0,816 & 1,000 \\
\hline $\begin{array}{l}\text { Gestão de Cuidados Nota Final - Rodízio } \\
5\end{array}$ & 0,999 & 0,859 & 0,778 \\
\hline Taxa de Ocupação - Rodízio 5 & 0,402 & 0,836 & 0,711 \\
\hline Complexidade do Paciente - Rodízio 5 & 0,695 & 0,806 & 0,222 \\
\hline Profissionais Disponíveis- Rodízio 5 & 0,935 & 0,965 & 0,762 \\
\hline Indicadores - Rodízio 5 & 0,964 & 0,264 & 0,249 \\
\hline Problemas - Rodízio 5 & 0,873 & 0,665 & 0,881 \\
\hline Liderança - Rodízio 5 & 0,981 & 0,688 & 0,451 \\
\hline Serviço de Limpeza - Rodízio 5 & 0,963 & 0,588 & 0,647 \\
\hline Elaboração de Projetos - Rodízio 5 & 0,813 & 0,794 & 0,996 \\
\hline $\begin{array}{l}\text { Gestão Adminstrativa1 Nota Final - } \\
\text { Rodízio } 5\end{array}$ & 0,950 & 0,759 & 0,458 \\
\hline Impressos - Rodízio 5 & 0,546 & 0,994 & 0,537 \\
\hline Relações Intersetoriais - Rodízio 5 & 0,513 & 0,985 & 0,543 \\
\hline Materiais Permanentes - Rodízio 5 & 0,925 & 0,487 & 0,602 \\
\hline Rotinas Diárias - Rodízio 5 & 0,950 & 0,708 & 0,398 \\
\hline $\begin{array}{l}\text { Gestão Administrativa } 2 \text { Nota Final - } \\
\text { Rodízio } 5\end{array}$ & 0,993 & 0,706 & 0,686 \\
\hline Amplia Conhecimento - Rodízio 5 & 0,996 & 0,936 & 0,866 \\
\hline Faz Pesquisa - Rodízio 5 & 0,700 & 0,060 & 0,146 \\
\hline Explica os Dados Levantados - Rodízio 5 & 0,318 & 0,336 & 0,998 \\
\hline Busca Relevante-Rodízio 5 & 0,374 & 0,167 & 0,771 \\
\hline Amplia a Busca - Rodízio 5 & 0,890 & 0,997 & 0,904 \\
\hline $\begin{array}{l}\text { Desenvolvimento Pessoal Nota Final - } \\
\text { Rodízio } 5\end{array}$ & 0,505 & 0,349 & 0,909 \\
\hline Apresentação Pessoal - Rodízio 6 & 0,951 & 0,641 & 0,333 \\
\hline Assiduidade- Rodízio 6 & 1,000 & 0,521 & 0,394 \\
\hline Pontualidade- Rodízio 6 & 0,982 & 0,693 & 0,716 \\
\hline Orientação - Rodízio 6 & 0,782 & 0,990 & 0,629 \\
\hline Material de Uso Pessoal - Rodízio 6 & 0,995 & 1,000 & 0,994 \\
\hline Postura - Rodízio 6 & 0,229 & 0,386 & 0,955 \\
\hline $\begin{array}{l}\text { Construção de Relacionamentos- } \\
\text { Rodízio } 6\end{array}$ & 0,696 & 0,958 & 0,827 \\
\hline Interesse- Rodízio 6 & 0,999 & 0,489 & 0,332 \\
\hline Organização e Liderança- Rodízio 6 & 0,963 & 0,858 & 0,938 \\
\hline $\begin{array}{l}\text { Responsabilidade e Compromisso - } \\
\text { Rodízio } 6\end{array}$ & 0,998 & 0,902 & 0,895 \\
\hline $\begin{array}{l}\text { Bases Comportamentais Nota Final - } \\
\text { Rodízio } 6\end{array}$ & 0,807 & 0,785 & 0,995 \\
\hline Anatomia e Fisiologia- Rodízio 6 & 0,910 & 0,018 & 0,013 \\
\hline Medicamentos - Rodízio 6 & 0,980 & 0,009 & 0,003 \\
\hline Relaciona exames - Rodízio 6 & 0,968 & 0,638 & 0,694 \\
\hline Dinâmica da Unidade - Rodízio 6 & 0,712 & 0,930 & 0,891 \\
\hline Programas de Saúde - Rodízio 6 & 0,949 & 0,962 & 0,782 \\
\hline Planeja e Organiza- Rodízio 6 & 0,983 & 0,998 & 0,991 \\
\hline Prioridades- Rodízio 6 & 0,465 & 0,710 & 0,917 \\
\hline Indicadores Epidemiológicos- Rodízio 6 & 0,820 & 0,022 & 0,029 \\
\hline Analisa Dados - Rodízio 6 & 0,758 & 0,957 & 0,886 \\
\hline Preenche Relatórios- Rodízio 6 & 0,933 & 0,967 & 0,994 \\
\hline $\begin{array}{l}\text { Conhecimentos Científicos nota Final - } \\
\text { Rodízio } 6\end{array}$ & 0,997 & 0,480 & 0,302 \\
\hline Técnicas básicas - Rodízio 6 & 0,852 & 0,855 & 0,426 \\
\hline Estado Clinico - Rodízio 6 & 0,765 & 0,109 & 0,216 \\
\hline
\end{tabular}




\begin{tabular}{|l|l|l|l|}
\hline Documenta as Ações - Rodízio 6 & 0,880 & 0,767 & 0,356 \\
\hline Consulta - Rodízio 6 & 0,259 & 0,998 & 0,157 \\
\hline $\begin{array}{l}\text { Analisa as Ações- } \\
\text { Rodízio 6 }\end{array}$ & 0,901 & 0,997 & 0,914 \\
\hline Organiza o Trabalho - Rodízio 6 & 0,705 & 0,968 & 0,813 \\
\hline Passagem de Plantão - Rodízio 6 & 0,940 & 0,374 & 0,121 \\
\hline $\begin{array}{l}\text { Pratica Assistencial Nota Final - Rodízio } \\
\text { 6 }\end{array}$ & 0,711 & 0,567 & 0,095 \\
\hline Educação em Saúde - Rodízio 6 & 0,998 & 0,996 & 0,984 \\
\hline Busca Extra Estágio - Rodízio 6 & 0,422 & 0,152 & 0,674 \\
\hline Raciocínio crítico - Rodízio 6 & 0,974 & 0,605 & 0,637 \\
\hline Apresentação do Trabalho - Rodízio 6 & 0,477 & 0,901 & 0,702 \\
\hline Domínio - Rodízio 6 & 0,042 & 1,000 & 0,019 \\
\hline Divisão das Tarefas - Rodízio 6 & 0,260 & 1,000 & 0,178 \\
\hline Ações Educativas Nota Final - Rodízio 6 & 0,779 & 0,596 & 0,138 \\
\hline Média Final & 0,979 & 0,106 & 0,024 \\
\hline
\end{tabular}


ANEXO 1- Currículo baseado em competências

\begin{tabular}{|c|c|c|c|c|}
\hline \multicolumn{5}{|c|}{ Carga horária total: $\mathbf{3 6 8 0}$ horas } \\
\hline \multicolumn{5}{|c|}{ MóDULO: 20 Semanas } \\
\hline \multicolumn{2}{|c|}{ Tempo de Integralização: } & \multicolumn{2}{|c|}{ Mínimo: 8 semestres } & $\begin{array}{c}\text { Máximo: } 15 \\
\text { semestres }\end{array}$ \\
\hline \multicolumn{2}{|c|}{ 10 PERÍODO } & TEORIA & ESTÁGIO & PRÁTICA \\
\hline 1 & $\begin{array}{l}\text { Bases Bioquímicas do } \\
\text { Organismo Humano I }\end{array}$ & $80 \mathrm{~h} / \mathrm{a}$ & & \\
\hline 2 & $\begin{array}{l}\text { Bases Morfofisiológicas } \\
\text { Organismo Humano I }\end{array}$ & $160 \mathrm{~h} / \mathrm{a}$ & & \\
\hline 3 & $\begin{array}{l}\text { Construção Do Conhec } \\
\text { na Área da Saúde }\end{array}$ & $40 \mathrm{~h} / \mathrm{a}$ & & \\
\hline \multirow[t]{3}{*}{4} & Contexto Epidemiológi & $120 \mathrm{~h} / \mathrm{a}$ & & \\
\hline & & $400 \mathrm{~h} / \mathrm{a}$ & & \\
\hline & TOTAL & $400 \mathrm{~h} / \mathrm{a}$ & & \\
\hline \multicolumn{2}{|c|}{ 20 PERÍODO } & TEORIA & ESTÁGIO & PRATICA \\
\hline 1 & Antropologia Cultural & $80 \mathrm{~h} / \mathrm{a}$ & & \\
\hline 2 & $\begin{array}{l}\text { Bases Bioquímicas do Organismo } \\
\text { Humano II }\end{array}$ & $80 \mathrm{~h} / \mathrm{a}$ & & \\
\hline 3 & $\begin{array}{l}\text { Bases Morfofisiológicas do } \\
\text { Organismo Humano II }\end{array}$ & $160 \mathrm{~h} / \mathrm{a}$ & & \\
\hline 4 & Instrumentos de Enfermagem I & $80 \mathrm{~h} / \mathrm{a}$ & & \\
\hline & SUBTOTAL & $400 \mathrm{~h} / \mathrm{a}$ & & \\
\hline & TOTAL PARCIAL & $800 \mathrm{~h} / \mathrm{a}$ & & \\
\hline \multicolumn{2}{|c|}{ 3 PERÍODO } & TEORIA & ESTÁGIO & PRATICA \\
\hline 1 & $\begin{array}{l}\text { Bases Fisiopatológicas do } \\
\text { Organismo Humano I }\end{array}$ & $160 \mathrm{~h} / \mathrm{a}$ & & \\
\hline 2 & Instrumentos de Enfermagem II & $160 \mathrm{~h} / \mathrm{a}$ & & \\
\hline 3 & $\begin{array}{l}\text { Metodologias de Pesquisa em } \\
\text { Enfermagem }\end{array}$ & $80 \mathrm{~h} / \mathrm{a}$ & & \\
\hline & SUBTOTAL & $400 \mathrm{~h} / \mathrm{a}$ & & \\
\hline & TOTAL PARCIAL & $1200 \mathrm{~h} / \mathrm{a}$ & & \\
\hline \multicolumn{2}{|c|}{ 4ㅇ PERÍODO } & TEORIA & ESTÁGIO & PRATICA \\
\hline 1 & $\begin{array}{l}\text { Bases Fisiopatológicas do } \\
\text { Organismo Humano II }\end{array}$ & $120 \mathrm{~h} / \mathrm{a}$ & & \\
\hline 2 & Enfermagem no Ciclo Vital & $240 \mathrm{~h} / \mathrm{a}$ & & \\
\hline 3 & Instrumentos de Enfermagem III & $80 \mathrm{~h} / \mathrm{a}$ & & \\
\hline & SUBTOTAL & $440 \mathrm{~h} / \mathrm{a}$ & & \\
\hline & TOTAL PARCIAL & $1640 \mathrm{~h} / \mathrm{a}$ & & \\
\hline \multicolumn{2}{|c|}{ 5o PERÍODO } & TEORIA & ESTÁGIO & PRATICA \\
\hline 1 & Educação em Saúde & $80 \mathrm{~h} / \mathrm{a}$ & & \\
\hline 2 & $\begin{array}{l}\text { Enfermagem no Ciclo V } \\
\text { (Situações Prevalentes) }\end{array}$ & $240 \mathrm{~h} / \mathrm{a}$ & & \\
\hline 3 & Instrumentos de Enferr & $80 \mathrm{~h} / \mathrm{a}$ & & \\
\hline & & $400 \mathrm{~h} / \mathrm{a}$ & & \\
\hline & TOTA & $2040 \mathrm{~h} / \mathrm{a}$ & & \\
\hline & ERÍODO & TEORIA & ESTÁGIO & PRATICA \\
\hline 1 & Enfermagem no Ciclo V & $320 \mathrm{~h} / \mathrm{a}$ & & \\
\hline
\end{tabular}




\begin{tabular}{|c|c|c|c|c|}
\hline & (Situações Especiais) & & & \\
\hline \multirow[t]{3}{*}{2} & Gestão em Saúde & $120 \mathrm{~h} / \mathrm{a}$ & & \\
\hline & SUBTOTAL & $440 \mathrm{~h} / \mathrm{a}$ & & \\
\hline & TOTAL PARCIAL & $2480 \mathrm{~h} / \mathrm{a}$ & & \\
\hline \multicolumn{2}{|c|}{ 70 PERÍODO } & TEORIA & ESTÁGIO & PRATICA \\
\hline \multirow[t]{3}{*}{1} & $\begin{array}{l}\text { Estágio Curricular } \\
\text { Supervisionado }\end{array}$ & & $340 \mathrm{~h}$ & \\
\hline & SUBTOTAL & $0 \mathrm{~h} / \mathrm{a}$ & $340 \mathrm{~h}$ & \\
\hline & TOTAL PARCIAL & $2480 \mathrm{~h} / \mathrm{a}$ & $340 \mathrm{~h}$ & \\
\hline \multicolumn{2}{|c|}{ 8 PERÍODO } & TEORIA & ESTÁGIO & PRATICA \\
\hline \multirow[t]{3}{*}{1} & $\begin{array}{l}\text { Estágio Curricular } \\
\text { Supervisionado }\end{array}$ & & $340 \mathrm{~h}$ & \\
\hline & SUBTOTAL & $0 \mathrm{~h} / \mathrm{a}$ & $340 \mathrm{~h}$ & \\
\hline & TOTAL PARCIAL & $2480 \mathrm{~h} / \mathrm{a}$ & $680 \mathrm{~h}$ & \\
\hline & Atividades Complementares & $240 \mathrm{~h}$ & & \\
\hline & TOTAL GERAL & $3400 \mathrm{~h} / \mathrm{a}$ & & \\
\hline
\end{tabular}


ANEXO 2 - Currículo baseado no ensino para compreensão

\begin{tabular}{|c|c|c|c|c|}
\hline \multicolumn{5}{|c|}{ Carga horária total: 3200 horas } \\
\hline \multicolumn{5}{|c|}{ Quantidade de ciclos: 01} \\
\hline \multicolumn{2}{|c|}{ Tempo de Integralização: } & Mínimo: 8 semestres & \multicolumn{2}{|c|}{$\begin{array}{l}\text { Máximo: } 15 \\
\text { semestres }\end{array}$} \\
\hline \multicolumn{3}{|c|}{ Módulo: $\quad$ APROXIMAÇÃO EM SAÚDE } & \multicolumn{2}{|c|}{$\mathrm{CH}$} \\
\hline Tipo & Descrição & & $\begin{array}{l}\text { Prática } \\
\text { (h) }\end{array}$ & $\begin{array}{l}\text { Teórica } \\
\text { (h/a) }\end{array}$ \\
\hline $\begin{array}{l}\text { Projeto } \\
\text { Integrado }\end{array}$ & Aproximação & Prática em Enfermagem & 160 & \\
\hline UCG & Saúde Coletiv & & & 160 \\
\hline UCG & Ser Humano $e$ & Relação & & 160 \\
\hline \multicolumn{3}{|c|}{$\begin{array}{l}\text { Módulo: CONHECIMENTOS E HABILIDADES NA } \\
\text { DIMENSÃO BIOLÓGICA }\end{array}$} & \multicolumn{2}{|c|}{$\mathrm{CH}$} \\
\hline Tipo & Descrição & & $\begin{array}{l}\text { Prática } \\
\text { (h) }\end{array}$ & $\begin{array}{l}\text { Teórica } \\
\text { (h/a) }\end{array}$ \\
\hline $\begin{array}{l}\text { Projeto } \\
\text { Integrado }\end{array}$ & $\begin{array}{l}\text { Conheciment } \\
\text { Dimensão Bic }\end{array}$ & $\begin{array}{l}\text { e Habilidades na } \\
\text { gica }\end{array}$ & 100 & \\
\hline UCG & $\begin{array}{l}\text { Constituição } \\
\text { Humano }\end{array}$ & Desenvolvimento & & 160 \\
\hline UCG & Metabolismo, & ontrole e Homeostase & & 160 \\
\hline \multicolumn{3}{|c|}{$\begin{array}{l}\text { Módulo: AGRESSÃO, DEFESA E } \\
\text { BIOSSEGURANÇA }\end{array}$} & $\mathrm{CH}$ & \\
\hline Tipo & Descrição & & $\begin{array}{l}\text { Prática } \\
\text { (h) }\end{array}$ & $\begin{array}{l}\text { Teórica } \\
\text { (h/a) }\end{array}$ \\
\hline UCG & Avaliação de & aúde do Indivíduo & & 160 \\
\hline UCG & Mecanismo d & Agressão e Defesa & & 160 \\
\hline $\begin{array}{l}\text { Projeto } \\
\text { Integrado }\end{array}$ & Vigilância Sa & ária & 100 & \\
\hline \multicolumn{3}{|c|}{$\begin{array}{l}\text { Módulo: SEMIOLOGIA, SEMIOTÉCNICA E } \\
\text { FARMACOLOGIA }\end{array}$} & $\mathrm{CH}$ & \\
\hline Tipo & Descrição & & $\begin{array}{l}\text { Prática } \\
\text { (h) }\end{array}$ & $\begin{array}{l}\text { Teórica } \\
\text { (h/a) }\end{array}$ \\
\hline UCG & Farmacologia & Semiotécnica & & 160 \\
\hline $\begin{array}{l}\text { Pratica } \\
\text { Profissional }\end{array}$ & $\begin{array}{l}\text { Práticas Profi } \\
\text { Semiotécnica }\end{array}$ & sionais em Semiologia e & 160 & \\
\hline UCG & Processos M & fofuncionais & & 160 \\
\hline \multicolumn{3}{|c|}{$\begin{array}{l}\text { Módulo: } \quad \text { ATENÇÃO PRIMÁRIA E SECUNDÁRIA À } \\
\text { SAUDE DO INDIVÍDUO }\end{array}$} & $\mathrm{CH}$ & \\
\hline Tipo & Descrição & & $\begin{array}{l}\text { Prática } \\
\text { (h) }\end{array}$ & $\begin{array}{l}\text { Teórica } \\
\text { (h/a) }\end{array}$ \\
\hline $\begin{array}{l}\text { Prática } \\
\text { Profissional }\end{array}$ & $\begin{array}{l}\text { Assistência } n \\
\text { Enfermagem }\end{array}$ & Atenção Secundária em & 160 & \\
\hline UCG & $\begin{array}{l}\text { Atenção Prim } \\
\text { do Individuo, }\end{array}$ & $\begin{array}{l}\text { ia e Secundaria a Saúde } \\
\text { amília e Comunidade }\end{array}$ & & 160 \\
\hline UCG & Processo de & abalho do Enfermeiro & & 160 \\
\hline \multicolumn{3}{|c|}{$\begin{array}{l}\text { Módulo: } \\
\text { INDIVIDUO }\end{array}$} & $\mathrm{CH}$ & \\
\hline Tipo & Descrição & & $\begin{array}{l}\text { Prática } \\
\text { (h) }\end{array}$ & $\begin{array}{l}\text { Teórica } \\
\text { (h/a) }\end{array}$ \\
\hline UCG & $\begin{array}{l}\text { Atenção Terc } \\
\text { Família e Cor }\end{array}$ & $\begin{array}{l}\text { ria à Saúde Do Individuo, } \\
\text { unidade. }\end{array}$ & & 160 \\
\hline UCG & Gestão em S & viços de Enfermagem & & 160 \\
\hline $\begin{array}{l}\text { Projeto } \\
\text { Integrado }\end{array}$ & Trabalho de & nclusão de Curso & 150 & \\
\hline \multicolumn{3}{|c|}{$\begin{array}{l}\text { Módulo: ESTÁGIO CURRICULAR } \\
\text { SUPERVISIONADO NAS ATENÇÕES PRIMÁRIA E } \\
\text { SECUNDÁRIA }\end{array}$} & $\mathrm{CH}$ & \\
\hline Tipo & Descrição & & $\begin{array}{l}\text { Prática } \\
\text { (h) }\end{array}$ & $\begin{array}{l}\text { Teórica } \\
\text { (h/a) }\end{array}$ \\
\hline $\begin{array}{l}\text { UCG- } \\
\text { ESTÁGIO }\end{array}$ & $\begin{array}{l}\text { Estágio Curri } \\
\text { Atenções Prir }\end{array}$ & $\begin{array}{l}\text { lar Supervisionado nas } \\
\text { ária e Secundária }\end{array}$ & 160 & \\
\hline ESTÁGIO & $\begin{array}{l}\text { Estágio Curri } \\
\text { Atenção Terc }\end{array}$ & $\begin{array}{l}\text { lar Supervisionado na } \\
\text { ria }\end{array}$ & 160 & \\
\hline
\end{tabular}




\begin{tabular}{|c|c|c|c|c|}
\hline \multicolumn{2}{|c|}{$\begin{array}{l}\text { Módulo: } \quad \text { ESTÁGIO CURRICULAR } \\
\text { SUPERVISIONADO NA GESTÃO DAS ATENÇÕES } \\
\text { PRIMÁRIA, SECUNDÁRIA E TERCIÁRIA }\end{array}$} & \multicolumn{2}{|c|}{$\mathrm{CH}$} & \multirow[b]{2}{*}{$\begin{array}{l}\text { Teórica } \\
\text { (h/a) }\end{array}$} \\
\hline Tipo & Descrição & & tica & \\
\hline $\begin{array}{l}\text { UCG- } \\
\text { ESTÁGIO }\end{array}$ & $\begin{array}{l}\text { Estágio Curricular em Gestão dos } \\
\text { Serviços de Atenção Primária e } \\
\text { Secundária }\end{array}$ & & 160 & \\
\hline $\begin{array}{l}\text { UCG- } \\
\text { ESTÁGIO }\end{array}$ & $\begin{array}{l}\text { Estágio Curricular em Gestão dos } \\
\text { Serviços de Atenção Terciária }\end{array}$ & & 160 & \\
\hline \multicolumn{5}{|c|}{ RESUMO DOS COMPONENTES CURRICULARES } \\
\hline \multicolumn{2}{|c|}{ CARGA HORÁRIA TOTAL = } & \multicolumn{3}{|c|}{1334} \\
\hline \multicolumn{2}{|c|}{ CORE CURRICULUM = } & \multicolumn{3}{|c|}{150} \\
\hline \multicolumn{2}{|c|}{ PRÁTICAS DE ENSINO = } & \multicolumn{3}{|c|}{0} \\
\hline \multicolumn{2}{|c|}{ PRÁTICA PROFISSIONAL = } & \multicolumn{3}{|c|}{320} \\
\hline \multicolumn{2}{|c|}{ PROJETO INTEGRADO = } & \multicolumn{3}{|c|}{510} \\
\hline \multicolumn{2}{|c|}{ ATIVIDADES COMPLEMENTARES $=$} & \multicolumn{3}{|c|}{246} \\
\hline \multicolumn{3}{|c|}{ UCG - ESTÁGIO/ESTÁGIO/ESTÁGIO SUPERVISIONADO = } & \multicolumn{2}{|c|}{640} \\
\hline \multicolumn{2}{|c|}{ TRABALHO DE CONCLUSÃO = } & \multicolumn{3}{|c|}{0} \\
\hline \multicolumn{2}{|c|}{ TOTAL DA CARGA HORÁRIA EM HORAS = } & \multicolumn{3}{|c|}{3200} \\
\hline
\end{tabular}


ANEXO 3 - Indicadores de avaliação UBS

\begin{tabular}{|c|c|}
\hline $\begin{array}{l}\text { PROFESSOR: } \\
\text { NOME: }\end{array}$ & MESTRE \\
\hline $\begin{array}{l}\text { BASES COMPORTAMENTAIS E ATITUDINAIS } \\
\begin{array}{lll}\mathrm{APL}=0,20 & \mathrm{AP}=0,10 \quad \mathrm{NA}=0,05\end{array}\end{array}$ & (0-2 PONTOS) \\
\hline $\begin{array}{l}\text { Apresentação pessoal (vestimenta, adornos, padronização do } \\
\text { visual, higiene) }\end{array}$ & \\
\hline $\begin{array}{l}\text { Responsabilidade e compromissos são cumpridos com } \\
\text { comportamento ético/profissional (prazos, comprometimento, } \\
\text { etc.) }\end{array}$ & \\
\hline Pontualidade & \\
\hline Assiduidade & \\
\hline Organização e liderança & \\
\hline $\begin{array}{l}\text { Postura pessoal / atitudes sociais (equilíbrio emocional, } \\
\text { cordialidade, comunicação verbal e não verbal, maneira de } \\
\text { sentar, agir, etc.) }\end{array}$ & \\
\hline $\begin{array}{l}\text { Construção de relacionamentos } \\
\text { multiprofissional, grupo e professor) }\end{array}$ & \\
\hline $\begin{array}{l}\text { Aceitação de orientação, críticas construtivas e capacidade de } \\
\text { assumi-las }\end{array}$ & \\
\hline $\begin{array}{l}\text { Identifica oportunidades de ampliar seus conhecimentos, } \\
\text { demonstrando interesse, empenho e dedicação pelo estágio, } \\
\text { iniciativa e pró-atividade }\end{array}$ & \\
\hline Utilização de material pessoal & \\
\hline OBSERVAÇÕES: & \\
\hline NOTA: & \\
\hline $\begin{array}{l}\text { CONHECIMENTOS CIENTÍFICOS } \\
\text { APL }=0,30 \quad A P=0,15 \quad \text { NA }=0,07\end{array}$ & (0-3 PONTOS) \\
\hline $\begin{array}{l}\text { Demonstra conhecimento sobre anatomia/fisiologia humana e o } \\
\text { processo fisiopatológico, correlacionando com a assistência } \\
\text { prestada }\end{array}$ & \\
\hline $\begin{array}{l}\text { Reconhece os medicamentos, ação, apresentação, efeitos } \\
\text { colaterais, via e forma de administração }\end{array}$ & \\
\hline $\begin{array}{l}\text { Correlaciona os resultados de exames com a evolução clínica } \\
\text { do paciente (identifica os resultados de exames) }\end{array}$ & \\
\hline $\begin{array}{l}\text { Apresenta iniciativa para reconhecer a dinâmica, fluxos e a } \\
\text { estrutura da unidade }\end{array}$ & \\
\hline $\begin{array}{l}\text { Reconhece os Programas de Saúde oferecidos pela Unidade e } \\
\text { pelo SUS. }\end{array}$ & \\
\hline $\begin{array}{l}\text { Iniciativa para planejar e organizar a unidade (previsão, } \\
\text { solicitação, armazenamento, controle, manutenção de } \\
\text { mat./med. e equipamentos). }\end{array}$ & \\
\hline $\begin{array}{l}\text { Consegue estabelecer prioridade para atender a demanda da } \\
\text { unidade e as ações propostas/responsabilidades }\end{array}$ & \\
\hline $\begin{array}{l}\text { Reconhece e sabe identificar os indicadores epidemiológicos, } \\
\text { sanitários e ambientais e realizar a notificação compulsória }\end{array}$ & \\
\hline $\begin{array}{l}\text { Levanta e analisa dados e informações completas após visitas } \\
\text { domiciliares e/ou em redes de apoio social, propondo "Ações de } \\
\text { Saúde" }\end{array}$ & \\
\hline $\begin{array}{l}\text { Preenche relatórios, livros, fichas específicas de registro e } \\
\text { prontuário do paciente de acordo com a rotina da UBS. }\end{array}$ & \\
\hline OBSERVAÇÕES: & \\
\hline NOTA: & \\
\hline \begin{tabular}{ccc}
\multicolumn{3}{c}{ PRATICA ASSISTENCIAL } \\
$\mathrm{APL}=0,43 \quad \mathrm{AP}=0,21 \quad \mathrm{NA}=0,10$ \\
\end{tabular} & (0-3 PONTOS) \\
\hline $\begin{array}{l}\text { Desenvolve técnicas básicas e específicas com conhecimento } \\
\text { técnico-científico }\end{array}$ & \\
\hline $\begin{array}{l}\text { Informa o estado clínico e reconhece minimamente a } \\
\text { complexidade do paciente a fim de criteriar e tomar decisão } \\
\text { (acolhimento) }\end{array}$ & \\
\hline $\begin{array}{l}\text { Documenta as ações de forma sistematizada e organizada, com } \\
\text { uso de vocabulários e nomenclatura específica as práticas de } \\
\text { enfermagem. }\end{array}$ & \\
\hline
\end{tabular}




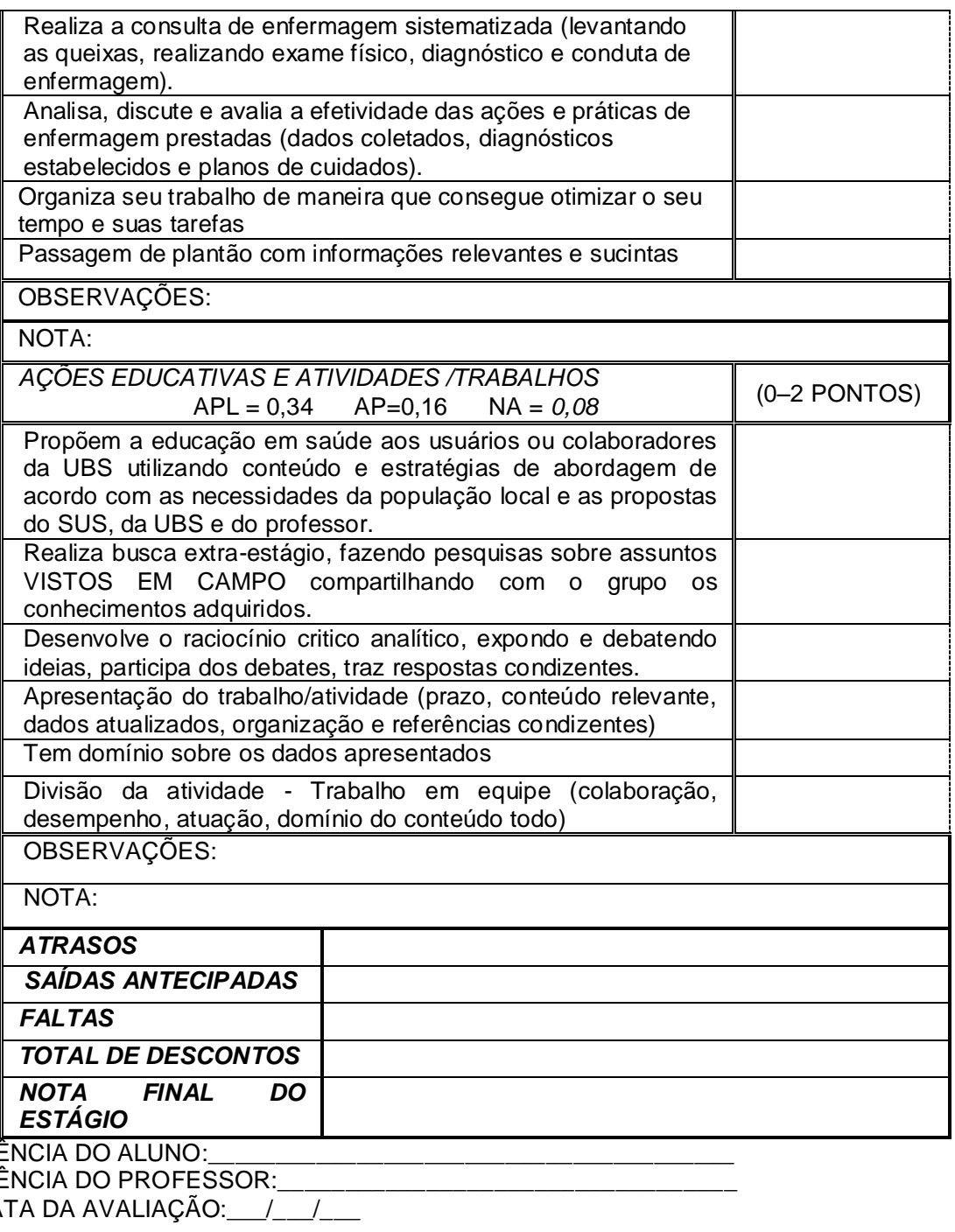


ANEXO 4- Indicadores de Avaliação Unidade de internação/ UTI

Local do Estágio:

Período:

a

Nome do Aluno:

Grupo:

\begin{tabular}{|c|c|c|c|}
\hline $\begin{array}{l}\text { ATITUDE E COMPORT AMENTO } \\
\text { (2,0 Pontos) }\end{array}$ & $\begin{array}{c}\text { Atende } \\
\text { Plenamente } \\
(0,182)\end{array}$ & $\begin{array}{c}\text { Atende } \\
\text { Parcialmente } \\
(0,127)\end{array}$ & $\begin{array}{c}\text { Não Atende } \\
(0,045)\end{array}$ \\
\hline \multicolumn{4}{|l|}{ Apresentação Pessoal } \\
\hline \multicolumn{4}{|l|}{ Assiduidade } \\
\hline \multicolumn{4}{|l|}{ Pontualidade } \\
\hline \multicolumn{4}{|l|}{ Postura Ética } \\
\hline \multicolumn{4}{|l|}{ Interesse, Envolvimento e Iniciativa } \\
\hline \multicolumn{4}{|l|}{$\begin{array}{l}\text { Comunicação verbal, não verbal e } \\
\text { escrita }\end{array}$} \\
\hline \multicolumn{4}{|l|}{$\begin{array}{l}\text { Aceitação de orientações } \\
\text { capacidade de assimilá-las }\end{array}$} \\
\hline \multicolumn{4}{|l|}{$\begin{array}{l}\text { Compromissos } \quad \text { assumidos } \\
\text { cumpridos no prazo estipulado }\end{array}$} \\
\hline \multicolumn{4}{|l|}{$\begin{array}{l}\text { Utilização de materiais de uso } \\
\text { pessoal }\end{array}$} \\
\hline \multicolumn{4}{|l|}{ Organização e liderança } \\
\hline \multicolumn{4}{|l|}{$\begin{array}{l}\text { Capacidade de relacionar-se com o } \\
\text { professor, grupo de estágio, } \\
\text { profissionais e pacientes }\end{array}$} \\
\hline $\begin{array}{l}\text { CONHECIMENTO CIENTíFICO }(3,0 \\
\text { Pontos) }\end{array}$ & $\begin{array}{c}\text { Atende } \\
\text { Plenamente } \\
(0,6) \\
\end{array}$ & $\begin{array}{c}\text { Atende } \\
\text { Parcialmente } \\
(0,4) \\
\end{array}$ & $\begin{array}{c}\text { Não Atende } \\
(0,1)\end{array}$ \\
\hline \multicolumn{4}{|l|}{$\begin{array}{lcc}\text { Demonstra } & \text { conhecimento } & \text { sobre } \\
\text { anatomia e } & \text { fisiologia do } & \text { corpo } \\
\text { humano } & & \\
\end{array}$} \\
\hline \multicolumn{4}{|l|}{$\begin{array}{lcc}\text { Reconhece } & 0 & \text { processo } \\
\text { fisiopatológico } & \text { relacionando-os aos } \\
\text { sinais clínicos } & & \end{array}$} \\
\hline \multicolumn{4}{|l|}{$\begin{array}{l}\text { Reconhece os medicamentos em } \\
\text { uso quanto à: indicação, efeitos } \\
\text { colaterais, dosagem e cuidados de } \\
\text { enfermagem }\end{array}$} \\
\hline \multicolumn{4}{|l|}{$\begin{array}{lr}\text { Realiza a leitura dos exames } \\
\text { diagnósticos } & \text { correlacionando-os } \\
\text { com os processos de saúde-doença }\end{array}$} \\
\hline \multicolumn{4}{|l|}{$\begin{array}{l}\text { Participa das visitas clínicas } \\
\text { realizadas em cada leito } \\
\text { argumentando de } \\
\text { adequada a terapêutica instituída de } \\
\text { acordo com os processos } \\
\text { fisiopatológicos encontrados }\end{array}$} \\
\hline $\begin{array}{c}\text { PRÁTICA ASSISTENCIAL }(3,0 \\
\text { Pontos) }\end{array}$ & $\begin{array}{c}\text { Atende } \\
\text { Plenamente } \\
(0,274)\end{array}$ & $\begin{array}{c}\text { Atende } \\
\text { Parcialmente } \\
(0,175)\end{array}$ & $\begin{array}{l}\text { Não Atende } \\
(0,05)\end{array}$ \\
\hline \multicolumn{4}{|l|}{ Reconhece a clientela assistida } \\
\hline \multicolumn{4}{|l|}{$\begin{array}{l}\text { Reconhece a Unidade quanto: } \\
\text { aspectos físicos, materiais e } \\
\text { humanos }\end{array}$} \\
\hline $\begin{array}{l}\text { Demonstra } \text { habilidade rér no } \\
\text { desenvolvimento de técnicas } \\
\text { básicas e específicas, com } \\
\text { segurança aos pacientes, de acordo } \\
\text { com a especificidade da Unidade }\end{array}$ & & & \\
\hline $\begin{array}{l}\text { Pratica a sistematização da } \\
\text { assistência de enfermagem, propõe } \\
\text { soluções adequadas para cada } \\
\text { situação }\end{array}$ & & & \\
\hline $\begin{array}{l}\text { Documenta as ações de forma } \\
\text { sistematizada e organizada, } \\
\text { utilizando } \text { terminologia } \\
\text { nomenclatura específica às práticas } \\
\text { de enfermagem }\end{array}$ & & & \\
\hline $\begin{array}{llr}\text { Demonstra } & \text { conhecimento } & \mathrm{e} \\
\text { habilidade no desenvolvimento de } \\
\text { cuidados especializados aos }\end{array}$ & & & \\
\hline
\end{tabular}




\begin{tabular}{|c|c|c|c|}
\hline \multicolumn{4}{|l|}{ pacientes com dispositivos invasivos } \\
\hline $\begin{array}{l}\text { Executa suas tarefas dentro do } \\
\text { prazo estipulado, organizando seu } \\
\text { tempo de maneira adequada }\end{array}$ & & & \\
\hline $\begin{array}{l}\text { Desenvolve as ações de } \\
\text { enfermagem segundo os critérios e } \\
\text { prioridades identificadas }\end{array}$ & & & \\
\hline $\begin{array}{l}\text { Propõe orientações fundamentadas } \\
\text { e consistentes aos } \\
\text { pacientes/familiares }\end{array}$ & & & \\
\hline $\begin{array}{l}\text { Analisa, discute e avalia a } \\
\text { efetividade das ações e práticas de } \\
\text { enfermagem prestadas }\end{array}$ & & & \\
\hline $\begin{array}{l}\text { Realiza a passagem de plantão com } \\
\text { informações relevantes e objetivas }\end{array}$ & & & \\
\hline PESQUISA (2,0 Pontos) & $\begin{array}{c}\text { Atende } \\
\text { Plenamente } \\
(0,286) \\
\end{array}$ & $\begin{array}{c}\text { Atende } \\
\text { Parcialmente } \\
(0,175) \\
\end{array}$ & $\begin{array}{c}\text { Não Atende } \\
(0,06)\end{array}$ \\
\hline $\begin{array}{l}\text { Realizou o estudo de caso dentro da } \\
\text { formatação exigida }\end{array}$ & & & \\
\hline $\begin{array}{l}\text { O conteúdo do trabalho é relevante } \\
\text { e atualizado }\end{array}$ & & & \\
\hline $\begin{array}{l}\text { Apresentou o estudo de caso com } \\
\text { segurança e domínio do conteúdo }\end{array}$ & & & \\
\hline $\begin{array}{l}\text { Propôs reuniões em grupo para } \\
\text { discussão de assuntos pertinentes à } \\
\text { Unidade }\end{array}$ & & & \\
\hline $\begin{array}{l}\text { A entrega do trabalho foi na data } \\
\text { estipulada }\end{array}$ & & & \\
\hline $\begin{array}{l}\text { Amplia a busca de informações para } \\
\text { suprir as necessidades individuais e } \\
\text { do grupo }\end{array}$ & & & \\
\hline $\begin{array}{l}\text { Identifica a oportunidade de ampliar } \\
\text { conhecimento }\end{array}$ & & & \\
\hline
\end{tabular}

Atitudes comportamentais ( 2,0 pontos)

Conhecimento Cientifico (3,0 pontos)

Prática assistencial ( 3,0 pontos)

Pesquisa (2,0 pontos)

Numero de faltas:

Total de atrasos e saídas antecipadas:

Desconto:

Média final:

Observações do aluno:

Assinatura do aluno:

Assinatura do professor: 


\section{ANEXO 5 - Indicadores de avaliação estágio de gestão}

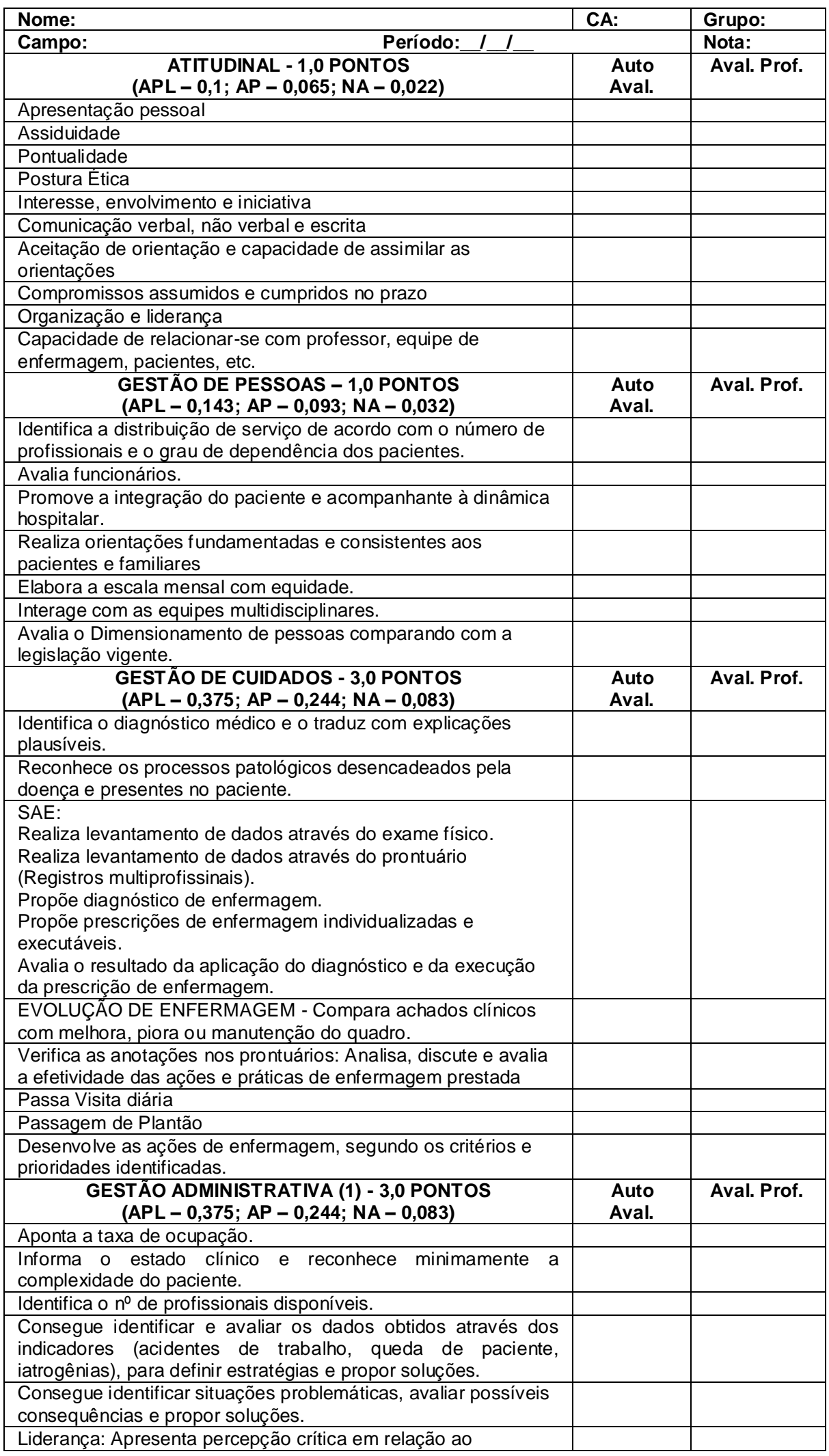




\begin{tabular}{|c|c|c|}
\hline \multicolumn{3}{|l|}{$\begin{array}{l}\text { funcionamento da Unidade e demonstra capacidade de } \\
\text { proposta de soluções. }\end{array}$} \\
\hline $\begin{array}{l}\text { Identifica a necessidade do serviço de limpeza e manutenção } \\
\text { dos materiais e equipamentos da unidade de trabalho. }\end{array}$ & & \\
\hline $\begin{array}{l}\text { Elabora e desenvolve projeto voltado para beneficiar o setor ou } \\
\text { Serviço e Enfermagem }\end{array}$ & & \\
\hline $\begin{array}{c}\text { GEST ÃO ADMINISTRATIVA (2) - 1,0 PONTOS } \\
(\text { APL }-0,25 ; \text { AP }-0,163 ; \text { NA - 0,055) }\end{array}$ & $\begin{array}{l}\text { Auto } \\
\text { Aval. }\end{array}$ & Aval. Prof. \\
\hline Identifica os impressos utilizados no setor. & & \\
\hline $\begin{array}{l}\text { Reconhece relações intersetoriais e fluxo dos eventos: } \\
\text { laboratório, rouparia, material de consumo, nutrição, farmácia, } \\
\text { internação (admissões, transferências e altas). }\end{array}$ & & \\
\hline $\begin{array}{l}\text { Conhece a rotina para prover a necessidade de recursos } \\
\text { materiais permanentes e de consumo. }\end{array}$ & & \\
\hline $\begin{array}{l}\text { Conhece as normas, rotinas e protocolos que envolvem a } \\
\text { atividade diária do pessoal de enfermagem (troca de } \\
\text { dispositivos de infusão, curativos, remanejamento de pessoal, } \\
\text { etc.). }\end{array}$ & & \\
\hline $\begin{array}{l}\text { DESENVOLVIMENTO PESSOAL - 1,0 PONTOS } \\
\text { (APL - 0,2; AP - 0,13; NA - 0,044) }\end{array}$ & $\begin{array}{l}\text { Auto } \\
\text { Aval. }\end{array}$ & Aval. Prof. \\
\hline Identifica oportunidades de ampliar conhecimento. & & \\
\hline Faz pesquisa sobre assuntos identificados como oportunidades. & & \\
\hline Sabe explicar os dados levantados nos estudos feitos. & & \\
\hline Faz busca relevante ao cotidiano da unidade. & & \\
\hline $\begin{array}{l}\text { Amplia a busca para suprir necessidades do grupo e não } \\
\text { apenas individuais. }\end{array}$ & & \\
\hline
\end{tabular}

apenas individuais.

APL - Atende Plenamente; AP - Atende Parcialmente; NA - Não Atende

ATRASOS E FALTAS: Número total de faltas e saída antecipada ou de atrasos: (0,25 ponto por falta) Tempo total: Desconto de nota: 
ANEXO 6 - Carta de autorização da instituição para coleta de dados.

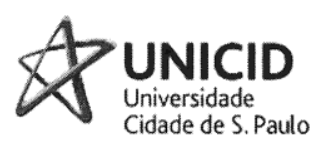

CARTA DE AUTORIZAÇÃO

Autorizamos a aluna de doutorado da Escola de Enfermagem Universidade de São Paulo, do Programa de pós Graduação em Gerenciamento em Enfermagem PPGEn, orientada pela Prof $\mathrm{Dr}^{\mathrm{a}}$ Maria Madalena Januário Leite a consultar os instrumentos de avaliação dos estudantes da Disciplina de Estagio Curricular Supervisionado dos anos de 2011 e 2012 do curso de enfermagem, com a finalidade de elaboração da pesquisa para sua tese de doutorado

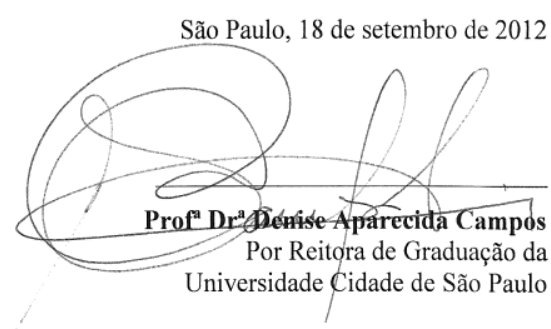


ANEXO 7 - Termo de sigilo do pesquisador

\section{Comitê de Ética em Pesquisa}

Termo de Comprometimento de Sigilo

Eu, Wana Yeda Paranhos, responsável pela pesquisa ESTAGIO CURRICULAR SUPERVISIONADO: UMA ANÁLISE DO DESEMPENHO DOS ESTUDANTES declaro meu comprometimento ético em manter o mais alto grau de segurança e sigilo em relação à consulta de dados de prontuários dos alunos, do CURSO DE GRADUAÇÃO EM ENFERMAGEM DA UNIVERSIDADE da qual recebi autorização formal para tal consulta.

Data:

Wana Yeda Paranhos

Assinatura do Pesquisador Responsável 